\title{
DIVERSIDADE GENÉTICA DE Miconia cinnamomifolia (D.C.) Naudin EM ÁREAS SOB INTERFERÊNCIA ANTRÓPICA NA MATA ATLÂNTICA
}

\author{
Veridiana Araujo Alves da Costa Pereira
}

Engenheiro Florestal

Orientador: Prof. Dr. PAULO YOSHIO KAGEYAMA

Dissertação apresentada à Escola Superior de Agricultura "Luiz de Queiroz", Universidade de São Paulo, para obtenção do título de Mestre em Recursos Florestais, com opção em Conservação de Ecossistemas Florestais.

P I R A C I C A B A

Estado de São Paulo - Brasil

Março - 2002 
Errata no. 1.

Na página 46, tabela 7 , onde se lê:

$\hat{A}$ igual número de alelos por loco,

Leia-se:

$\mathrm{N}$ : número de locos utilizados

Errata no, 2

Na página 52, acrescentar parágrafo:

Embora a Área Mínima Viável tenha sido calculada com base em estimativas do Ne visando à conservação in situ, pode-se perceber que este índice se adequa melhor à conservação ex situ desta população. Isto deve-se ao fato desta população ter se formado a partir da intervenção antrópica, constituindo-se atualmente uma formação secundária. 
Dados Internacionais de Catalogação na Publicação (CIP) DIVISÃo DE BIBLIOTECA E DOCUMENTAÇÃO - ESALQ/USP

Pereira, Veridiana Araújo Alves da Costa

Diversidade genética de Miconia cinnamomifolia (D.C.) Naudin em áreas sob

interferência antrópica na Mata Atlântica / Veridiana Araújo Alves da Costa Pereira. -

- Piracicaba, 2002.

84 p. : il.

Dissertação (mestrado) - . Escola Superior de Agricultura Luiz de Queiroz, 2002.

Bibliografia.

1. Árvores florestais 2. Diversidade genética 3. Mata Atlântica 4. Populaçōes vegetais 5 . Recursos genéticos vegetais I. Título

CDD 634.97342

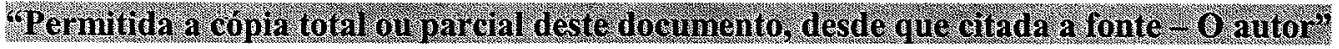


Meu pé de jacatirão

Cresce em meu coração uma árvore.

Há dentro de mim Um pé de jacatirão...

Rude, agreste, humilde, solitário, festivo, frondoso, majestoso e colorido.

No outono e no inverno, sou esperança;

no verão,

sou festa de amor e cor, resplandeço flores e luzes, cúmplice do sol. E então eu me envaideço, sou feliz.

O mundo inteiro é uma aquarela e eu pinto a vida com as minhas cores.

Corre em minhas veias a seiva, o sangue, de um pé de jacatirão... 


\section{Agradecimentos}

Ao Prof. Paulo Yoshio Kageyama, pela confiança e apoio durante a pesquisa e pela grande amizade.

Pelo apoio logístico, agradeço ao Diretor de Meio Ambiente da Companhia Suzano Papel e Celulose, $\mathrm{Eng}^{\mathrm{O}}$ Paulo Groke.

Ao Gerente Valdemir e funcionários Rinaldo, Aldo e Edna, da Fazenda Itapanhaú, pelo inestimável apoio logístico durante os trabalhos de campo.

Ao Sr. Nelson, pela sabedoria com que nos guiou pela floresta, pelo bom humor de sempre e as histórias de um homem que sabe tudo de mata.

Ao Eng ${ }^{0}$. Marcelo Conde, pela ajuda na elaboração dos mapas e busca das fotos aéreas.

Com muito carinho agradeço à Patrícia, amigona do peito nas horas mais difíceis e também nas horas legais e ao amigo Sacolinha.

Às amigas Tais e Karina, que me acompanharam no campo e não pouparam esforços para me ajudar, não me deixando perder nas contas e enfrentando cobras e até polícia florestal.

Ao amigo Alexandre Magno Sebbenn, que entende tudo de isoenzimas e análises genéticas agradeço os ensinamentos, a paciência e a amizade.

Ao amigo Luciano Ribas pela leitura do trabalho e comentários.

Ao amigo Israel Gomes Vieira e sua equipe de coleta de sementes (Setor de Sementes do IPEF), em especial ao Bambu, José Cardoso e José Maria que enfrentaram os jacatirões em dia de sol, chuva, ventania, frio etc... 
A equipe de laboratório Elza, Gelson, Maria e especialmente Andréia, que me ensinou a técnica de eletroforese.

Ao Amarildo, Luciana e Seu Chico (Viveiro do LCF), agradeço o cuidado com as mudas.

Aos amigos de casa Viviane, Giuliana, Isis pela grande amizade e convivência.

Ao amigos Prof. Flávio Gandara, Pesquisadora do IAC Maria Beatriz Perecin e Prof. Ricardo Ribeiro Rodrigues que ajudaram com comentários e uma leitura atenta ao trabalho para a qualificação.

Ao Pesquisador do IAC Francisco de Paula Nogueira, agradeço a disponibilidade no levantamento das fotos aéreas antigas para a composição do histórico da área.

A todo o pessoal do Departamento de Ciências Florestais e aos colegas do Curso de Pós Gradução.

Ao CNPq pelo apoio financeiro.

Aos amigos Rogério Oliveira Naressi e Ivo Rosa Filho pelas soluções com os programas e problemas computacionais.

Ao pessoal do Xerox do CALQ pela assistência na impressão.

Ao amigo Paulo van Breugel pela ajuda com a tradução para o Inglês.

Ao Paulinho da Biblioteca do IPEF e a Eliana e Silvia (Biblioteca Central) pela correção das citações bibliográficas.

À minha irmã Viviane, que não se contentou em fazer a revisão gramatical inicial do trabalho e foi a campo, conhecer o mato.

Aos meus pais, Francisco e Lourdes, pelo incentivo ao estudo, apoio e preocupação comigo em todas as etapas da minha vida.

Ao meu marido Leandro, pelo amor que me dedica todos os dias, pela paciência com a qual aguentou firme as minhas ausências e também pela ajuda nos trabalhos de campo, etc... 


\section{SUMÁRIO}

Página

RESUMO. viii

SUMMARY $\mathbf{X}$

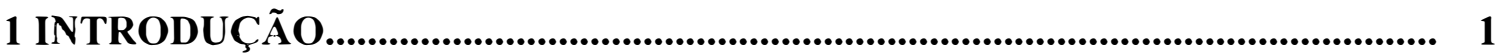

2 REVISÃO DE LITERATURA...................................................................... 4

2.1 histórico da perturbação e fragmentação................................................................ 4

2.2 Estrutura genética de populações e conservação in situ ........................................ 9

2.3 Diversidade da floresta tropical...................................................................................... 12

2.4 Uso de marcadores genéticos........................................................................................ 15

2.5 A espécie........................................................................................................................ 16

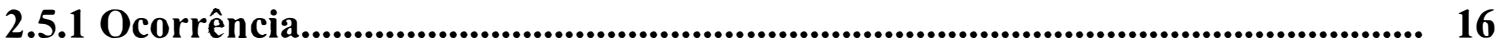

2.5.2 Descrição morfológica............................................................................................ 17

2.5.3 Fenologia e dinâmica sucessional................................................................. 17

2.5.4 Importância e utilidade................................................................................ 18

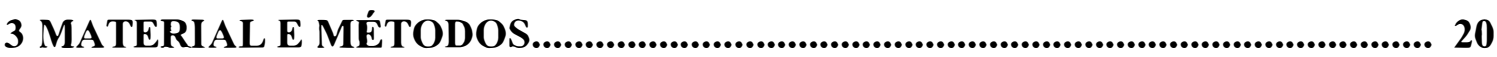

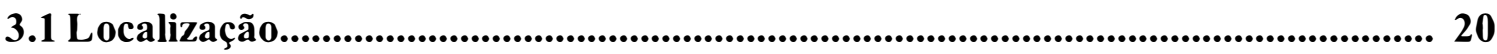

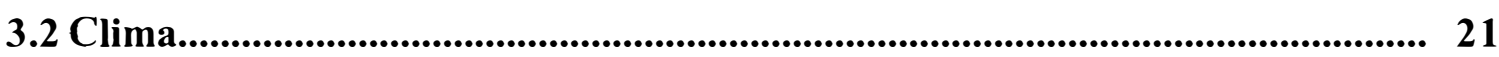

3.3 Vegetação................................................................................................................ 21

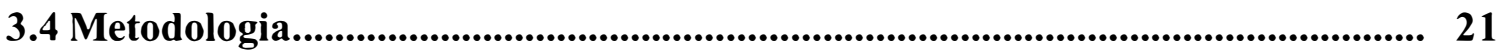

3.4.1 Levantamento do histórico........................................................................ 21

3.4.2 Amostragem e coleta do material vegetativo..................................................... 22

3.4.3 Desenvolvimento do protocolo............................................................................... 23

3.4.4 Variabilidade genética: análise estatística............................................................ 26

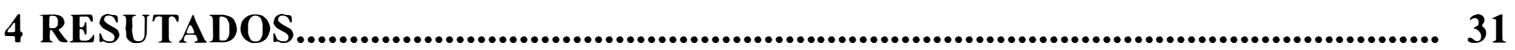


4.1 Histórico da fragmentação do local de estudo....................................................... 31

4.2 Descontinuidade das subpopulações de Miconia cinnamomifolia..................... 37

4.3 Desenvolvimento do protocolo e interpretação genética.................................... 39

4.4 Variabilidade genética................................................................................................ 42

4.4.1 Riqueza e freqüências alélicas..................................................................... 42

4.4.2 Índices de diversidade intrapopulacional............................................................. 44

4.4.3 Estrutura genética das subpopulações........................................................... 47

4.5 Sistema de reprodução....................................................................................................... 49

4.5.1 Teste de ajuste ao Equilíbrio de Hardy-Weinberg........................................ 49

4.5.2 Taxa de cruzamento aparente............................................................................... 50

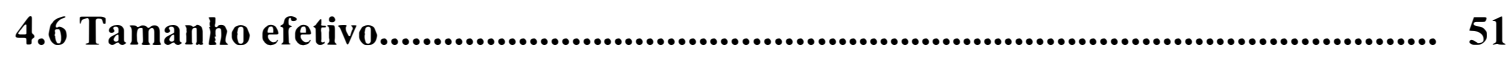

4.7 Estrutura genética espacial................................................................................. 52

4.8 Distribuição diamétrica da M. cinnamomifolia simulação da diversidade genética em uma população manejada........................................................................... 55

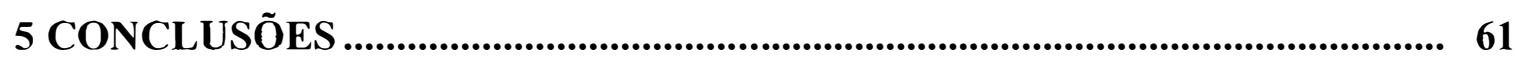

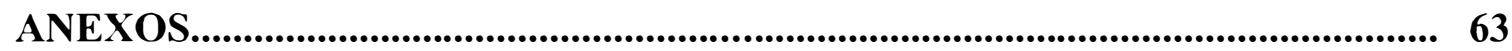

REFERÊNCIAS BIBLIOGRÁGICAS............................................................ 73 


\title{
DIVERSIDADE GENÉTICA DE Miconia CINNAMOMIFolia (D.C.) NAUdin EM ÁREAS SOB INTERFERÊNCIA ANTRÓPICA NA MATA ATLÂNTICA.
}

\author{
Autora: VERIDIANA ARAUJO ALVES DA COSTA PEREIRA \\ Orientador: Prof. Dr. PAULO YOSHIO KAGEYAMA
}

\section{RESUMO}

Existe atualmente a necessidade de um melhor entendimento dos processos ecológicos e genéticos pelos quais as espécies passaram, uma vez que, durante o processo de ocupação de terras, muitas espécies sofreram erosão genética e até hoje ainda sofrem pressão antrópica. As conseqüências genéticas do processo de isolamento, provocado pela fragmentação, têm sido estudadas principalmente paras as espécies secundárias, raras em suas maioria, por estas necessitarem de áreas maiores para sua conservação. Em relação às espécies dos grupos iniciais da sucessão estes estudos são ainda preliminares, embora estas espécies exerçam papel de iniciadoras do processo de sucessão, tanto em áreas de florestas, pela colonização das clareiras, quanto em áreas que sofreram fortes intervenções antrópicas. O trabalho teve como objetivo realizar o estudo genético de duas subpopulações de Miconia cinnamomifolia (DC) Naud, sob condições de intervenção antrópica, visando dar subsídios à conservação genética e ao manejo de populações naturais de espécies arbóreas em áreas de florestas secundárias. A extração seletiva de madeira e a produção de carvão na década de 60 para abastecimento da siderurgia na Região de Mogi das Cruzes provavelmente propiciaram a abertura de grandes clareiras no fragmento estudado, que foram ocupadas pelo jacatirão. A partir do desenvolvimento do protocolo de eletroforese e análise de isoenzimas, foi possível estimar a variabilidade e estrutura genética, o sistema reprodutivo e a distribuição espacial dos genótipos de duas subpopulações. Foram obtidos 
17 alelos distribuídos em 7 locos polimórficos. Os índices de diversidade estimados para as subpopulações revelaram um alto número de alelos por loco $(\hat{A}=2,3)$ e uma alta porcentagem de locos polimórficos $(\hat{P}=0,92)$. A heterozigosidade esperada foi de 0,381 e a heterozigosidade observada foi de 0,406 , evidenciando que a população possui excesso de heterozigotos. Obteve-se índices de fixação de Wright negativos $(\hat{f}=-0,071 ; \hat{F}=-0,08)$, indicando que a população está em Equilíbrio de Hardy-Weinberg. Apenas dois locos não se ajustaram às proporções do Equilibrio. O coeficiente de coancestralidade de Cockerham também foi negativo $\left(\hat{\theta}_{p}=-0,008\right)$, revelando que não existe divergência entre as subpopulações. O sistema de reprodução foi caracterizado a partir da taxa de cruzamento aparente. A média da taxa de cruzamento aparente $\left(\hat{t}_{a}\right)$ foi 0,965 . A estimativa do tamanho efetivo $\left(\hat{N}_{e}\right)$ foi de 103 árvores para a população, número maior que o tamanho da amostra, evidenciando que é necessário uma amostragem maior da população. Em relação a estruturação espacial dos genótipos foi possível concluir, através do Índice de Moram obtido para as duas subpopulações, que existe uma clara estruturação dos genótipos para as menores classes de distância, revelando que os indivíduos mais próximos tem um certo grau de parentesco, o que provavelmente levará à endogamia nas gerações futuras. Através da simulação de cortes seletivos na floresta, foi realizada uma nova análise dos índices de diversidade e freqüências alélicas para avaliação de como uma intervenção de extração de madeira pode interferir na estrutura genética desta população. Os índices de diversidade praticamente não sofreram alteração, porém foram perdidos dois alelos da subpopulação 2 que se encontravam em baixa freqüência. 


\title{
GENETIC DIVERSITY OF Miconia cinnamomifolia (D.C.) Naudin IN ANTHROPOGENIC AREAS OF ATLANTIC RAIN FOREST.
}

\author{
Author: VERIDIANA ARAUJO ALVES DA COSTA PEREIRA \\ Adviser: Prof. Dr. PAULO YOSHIO KAGEYAMA
}

\section{SUMMARY}

For a better conservation of sustainable management of species, a good understanding of the ecological and genetic processes of these species is essential. This is especially true as many species suffered and are still suffering genetic erosion due to land use changes, fragmentation and subsequent isolation and other anthropogenic pressure. Studies about the genetic consequences of isolation due to fragmentation have mostly focused on secondary species. These species are often rare and therefore need relatively large areas for their conservation. So far, attention for early secondary and pioneer species has been limited. Even though these species play a key role in the initial phase of the succession, both in natural forest, through the colonization of gaps, and in areas that suffered from strong anthropogenic disturbances. The objective of the work presented here is to study the genetic structure of two subpopulations of Miconia cinnamomifolia (DC) Naud that suffered anthropogenic disturbances, aiming to support the genetic conservation and management of natural populations in secondary forests. The selective logging and production of charcoal for the siderurgy in the region around Mogi das Cruzes in the 1960s has probably contributed to the opening of large gaps in the studied fragment. These gaps were colonized by $M$. cinnamomifolia. Based on isozyme analysis, the 
genetic variability, genetic structure, mating system, and spatial distribution of the genotypes of the two studied subpopulations were estimated. In total 17 alleles were found, distributed over 7 polymorphic loci. The estimates of indices of diversity for the average for two subpopulations showed high number of alleles for each locus $(\hat{A}=2,3)$ as well as high polymorphism $(\hat{P}=0,92)$. The heterozygosity $\left(\hat{H}_{e}\right)$ was 0,381 and the observed heterozygosity ( $\left.\hat{H}_{0}\right)$ 0,406. This indicates that the subpopulations have an excess of heterozygotes. The Wright's F statistics have negative values (the average for both subpopulations is $\hat{f}=-0,071 ; \hat{F}=-0,08)$, indicating that the populations are in Hardy-Weinberg Equilibrium. The Cockerham coefficient of co-ancestry was negative $\left(\hat{\theta}_{p}=-0,008\right)$, revealing that no divergence between the subpopulations exists. Only two loci did not show Hardy Weinberg frequency distribution. The reproductive system was characterized based on the estimation of apparent outcrossing rate $\left(\hat{t}_{a}\right)$. The average of the apparent outcrossing rate $\left(\hat{t}_{a}\right)$ was 0,965 . The population effective size $\left(\hat{N}_{e}\right)$ was estimated to be 103. This is more than the number of trees that were sampled. This proves that 95 trees sampled represent 103 tree in a pamitic population. As for the spatial structure of the genotypes, it was possible to conclude, through the Index of Moran, that for the smaller distance classes, the genotypes were clearly structured. This shows that neighboring individuals in general are more related. This will probably lead to an increase in inbreeding in future generations. To evaluate the impact of selective logging on the genetic structure of these two subpopulations, selective logging was simulated and the diversity index and alleles frequencies were again calculated. The diversity indices did hardly change. However two alleles, which were found in low frequencies in subpopulation 2 were lost in this population. 


\section{INTRODUÇÃO}

A destruição dos ecossistemas naturais, seja para extração de recursos florestais ou para dar lugar a sistemas produtivos, como a agricultura e pecuária, tem gerado o desequilíbrio ambiental que culmina em grandes problemas como poluição, perda de recursos hídricos e perda de solo. Em um nível mais complexo, e até hoje não levado em consideração quando se procura alcançar a sustentabilidade no manejo dos recursos naturais, essa destruição tem levado à extinção dos recursos genéticos.

A floresta tropical apresenta a maior complexidade e diversidade de espécies, com cerca de 400 espécies arbóreas por hectare segundo SOS Mata Atlântica (1996) e, portanto, constitui uma reserva genética até hoje inestimável, estando, no Estado de São Paulo, em grande parte concentrada na Mata Atlântica. Essa configuração, caracterizada por pequenas áreas remanescentes e isoladas, não traz uma boa perspectiva para a conservação, pois o isolamento pode promover a extinção de espécies pela perda de variabilidade genética e, consequentemente, a capacidade de adaptação às mudanças ambientais.

Neste contexto, os fragmentos mantidos por propriedades particulares são de grande importância para o bioma em questão, abrigando populações de diversas espécies, mantendo assim a possibilidade de fluxo gênico entre remanescentes protegidos em Unidades de Conservação da Floresta Atlântica, ou seja, auxiliando na manutenção da sua biodiversidade. Atualmente empresas e propriedades particulares têm como meta abandonar áreas anteriormente cultivadas para aumentar as áreas de conservação em função da adequação ambiental visando atender a legislação florestal e também os critérios da certificação florestal, como Selo Verde e ISO 14000. Segundo Almeida (2001) a globalização das questões ambientais trouxe algumas mudanças no 
comportamento empresarial de setores de maior impacto sobre o meio ambiente, como os químicos, de papel e celulose, siderúrgico e de mineração, entre outros.

Sob este aspecto, o conhecimento da distribuição da variabilidade genética de espécies representantes de alguns grupos ecológicos localizadas nestes remanescentes é de extrema importância, já que servirão como aporte de sementes e contribuirão para a restauração de áreas adjacentes, anteriormente cultivadas. Através do estudo da estrutura genética e reprodução destas espécies é possível avaliar o processo evolutivo pelo qual suas populações passaram e quais mecanismos são importantes para a manutenção do equilíbrio, uma vez que, durante a ocupação das terras, muitas espécies sofreram erosão genética e ainda hoje sofrem pressão antrópica.

A conservação in situ dos recursos genéticos tem sido apontada como a melhor alternativa para recursos florestais, principalmente no tocante à enorme diversidade da floresta tropical, considerando a necessidade de se levar em conta o ecossistema e as interações complexas de suas espécies, pois, segundo Namkoong (1983), o objetivo da preservação da diversidade natural deve passar pela preservação da dinâmica da evolução das espécies e suas estruturas, ou seja, garantir que elas continuem a ter a capacidade de evoluir e manter sua variabilidade genética.

Em relação à escolha das espécies para a realização de estudos genéticos e ecológicos é importante entender o papel que a espécie focal representa para o bioma em questão e também qual sua importância para o componente humano, uma vez que este vem sendo o principal responsável pelas ações de uso e degradação. No presente estudo a espécie escolhida, Miconia cinnamomifolia DC. Naudin, conhecida popularmente como jacatirão, é representativa da condição de sucessão secundária a partir da intervenção antrópica, como extração seletiva de madeira na Mata Atlântica. Sob condição antropizada forma maciços de indivíduos e na floresta primária é uma espécie relativamente rara.

Kageyama \& Reis (1993) propõem que as novas populações que compõe estas áreas podem apresentar um aumento ou diminuição da variabilidade genética, dependendo do processo de colonização de cada área, e sugerem que florestas de vegetação secundária podem ter potencial para manejo sustentável de madeira, através 
da exploração seletiva e indução da regeneração natural de algumas espécies e, também a utilização de outros produtos não madeireiros.

A conservação da biodiversidade na floresta tropical depende atualmente de estudos de ecologia e genética que utilizem indicadores precisos relacionados à composição, estrutura da floresta e aspectos funcionais. O componente genético está inserido nestes três atributos da diversidade (Redford \& Ritcher,1999), sendo que os índices de diversidade, como número de alelos, diversidade gênica, freqüência genotípica e fluxo gênico, entre outros, são citados por Namkoong et al. (2000) como possíveis indicadores para verificação da sustentabilidade de práticas de manejo florestal. Portanto, para a melhor orientação do manejo sustentável e conservação dos recursos naturais, deve-se levar em conta a dimensão genética das mudanças ocorridas ao longo do tempo em uma determinada paisagem e sua interação com a ecologia, e não basear a sustentabilidade somente em dados demográficos.

O presente trabalho se propõe a caracterizar um fragmento da Mata Atlântica através do levantamento do histórico de perturbação que condicionou o aparecimento de formações contínuas de Miconia cinnamomifolia (DC) Naud e realizar o estudo genético desta espécie representativa da condição de antropização da floresta tropical. Este estudo visa dar subsídios à conservação genética e ao manejo de populações naturais de espécies arbóreas em áreas de florestas secundárias através dos seguintes objetivos específicos:

$\checkmark$ Caracterização de um fragmento florestal a partir do levantamento do histórico de perturbação em área remanescente da Floresta Ombrófila Densa, Região de Biritiba Mirim, SP.

$\checkmark$ Desenvolvimento do protocolo de análise eletroforética isoenzimática para Miconia cinnamomifolia (DC) Naud.

$\checkmark$ Quantificação da variabilidade genética em duas subpopulações de Miconia cinnamomifolia (DC) Naud. sob condições de intervenção antrópica.

$\checkmark$ Verificação da existência de estruturação genética espacial dessas subpopulações.

$\checkmark$ Desenvolvimento de uma simulação dos índices de variabilidade genética sob duas intensidades de desbaste da espécie. 


\section{REVISÃO DE LITERATURA}

\subsection{Histórico da perturbação e fragmentação}

O histórico da destruição das florestas no Brasil está intrinsecamente ligado ao desenvolvimento da economia do País desde a época do seu descobrimento. Como exemplo desta afirmação temos a exploração do Pau Brasil (Caesalpinia echinata), iniciada um ano após o descobrimento, para extração da brasilina, matéria corante empregada no tingimento de tecidos e tinta de escrever além de madeira para construção civil, naval e movelaria, constituindo assim o primeiro ciclo da economia brasileira. Pode-se mesmo afïmar que o alto valor do Pau Brasil foi a principal causa da devastação inicial das matas litorâneas do país (Leão, 2000).

A partir do cultivo da cana de açúcar para abastecimento dos engenhos, aliada à contínua exploração das diversas madeiras da Mata Atlântica, tais como o jacarandá, maçaranduba, cedro, imbuia, a devastação das florestas de domínio da Mata Atlântica continuou. Em 1711, o jesuíta André Antonil estabeleceu regras para orientar o plantio da cana de açúcar: "roça-se, queima-se e alimpa-se, tirando-lhe tudo o que pode servir de embaraço". Neste caso, a palavra embaraço significa a própria Mata Atlântica, que dificultava a exploração das terras (WWF, 2001).

O terceiro ciclo da economia foi a cultura cafeeira, que direcionava inclusive os rumos políticos do País. A expansão do café em meados do século XX contribuiu para a criação de inúmeras cidades do Estado de São Paulo, expandindo o cultivo no sentido do interior, completando a destruição dos ecossistemas naturais. Segundo os ensinamentos da época, as terras onde existiam matas virgens eram as mais indicadas para o plantio do 
café e o procedimento para o cultivo era o corte da floresta, destoca e queima dos resíduos.

No Brasil, os processos de ocupação e abertura de terras, principalmente para a agricultura e pecuária (mas também para outras atividades), têm sido marcados pela perspectiva temporal dos agentes responsáveis. Até meados deste século, a população do país era tão escassa em relação à extensão do seu território que não se dava menor atenção aos impactos ambientais da exploração de seu espaço. Sendo abundantes, as terras continuavam a ser usadas enquanto sua fertilidade natural propiciasse retorno aceitável. Quando isso deixava de ocorrer, eram abandonadas e avançava-se sobre novas áreas, numa exploração sempre extensiva. Até recentemente, a própria lavoura do café atividade que por quase um século liderou a economia brasileira - expandiu-se dessa forma (Baer \& Mueller, 1995).

Com o declínio da cultura cafeeira, a estrutura de divisão das terras do estado foi modificando-se aos poucos, onde os latifúndios deram lugar à pequena e média propriedade e este fato contribuiu para o retalhamento dos fragmentos das matas ainda existentes, principalmente no interior do Estado de São Paulo (Leão, 2000).

Para as áreas próximas ao litoral, a agressão mais recente neste histórico de perturbação vem sendo a especulação imobiliária em áreas de floresta, mangues e restingas e a ocupação das áreas de conservação por posseiros além da exploração predatória de algumas espécies, como palmito e bromélias. Atualmente, a vegetação que ocorre ao longo da encosta atlântica no Estado de São Paulo configura a área florestada de Mata Atlântica mais expressiva, principalmente por situar-se em escarpas íngremes e de difícil acesso e aproveitamento (Mantovani et al., 1990) e em Unidades de Conservação.

A fragmentação é resultado de um processo de ruptura na continuidade de habitats naturais. Este processo tem sua origem por causas antrópicas, em que a estrutura da paisagem é modificada, resultando em mudanças na composição e diversidade das comunidades. Este grau de ruptura pode ser medido pelo número de fragmentos, área destes fragmentos, posição e distância entre eles, proporção entre área de borda e grau de circularidade de um determinado fragmento ( Hanski \& Simberloff, 1997). 
Entre os fatores ambientais associados à fragmentação podemos destacar também a importância do estudo do histórico de perturbação, que consiste no levantamento de todas as atividades, principalmente antrópicas, que ocorreram na área (Oliveira,1997). Segundo Viana (1990), a Floresta Atlântica experimentou pelo menos algum tipo de perturbação nos últimos quatro séculos. Áreas primárias são praticamente inexistentes e em locais de dificil acesso, portanto quando avalia-se estes fragmentos deve-se levar em conta os fenômenos naturais pelos quais as espécies podem ter passado, dentre os quais destacam-se no presente trabalho os processos genéticos como deriva, seleção e migração.

Segundo Marrucci (1999), a história da paisagem expõe os modelos evolucionários específicos de cada paisagem revelando os estágios ecológicos, períodos culturais e processos chaves que ocorrem na dinâmica espacial e temporal. Desta maneira é uma valiosa ferramenta por fazer uma descrição da paisagem, uma predição e a prescrição para o planejamento.

Em relação à área dos fragmentos, de acordo com a teoria de Biogeografia de Ilhas de MacArthur e Wilson (1967), quanto menor um fragmento, menor é a capacidade de suportar uma população e portanto menor a diversidade de espécies, mesmo porque um fragmento menor provavelmente estará mais sujeito às pressões externas.

Esta discussão sobre os SLOSS (single large or several small) foi bastante forte durante as décadas de 70-80 para tentar-se definir se o melhor método no tocante a conservação dos recursos naturais seria em diversos remanescentes pequenos ou em uma única grande área. Atualmente este conceito tem sido substituído pelas teorias de metapopulação e ecologia da paisagem, por não levar em consideração o grau de isolamento dos fragmentos e a disposição espacial destes na paisagem.

Segundo Hanski \& Simberloff (1997) o enfoque de metapopulação serve para designar um conjunto de populações espacialmente estruturadas em agrupamentos de populações reprodutivas e que a migração entre as populações locais tem algum efeito na dinâmica local, incluindo a possibilidade de restabelecimento da população após extinção. A abordagem deste conceito abrange uma escala regional e considera a importância de cada mancha (patch), resgatando desta maneira a importância dos 
pequenos fragmentos para a conexão das populações distribuídas na paisagem e atribui conceitos aos fragmentos em relação à disponibilidade de recursos.

O grande problema ainda para trabalhar-se com fragmentos é que os modelos desenvolvidos não levam em consideração a matriz, ou seja a porosidade das culturas e atividades humanas entre os fragmentos. Forman \& Godron (1986) também discutem o tema, sob este enfoque, ou seja, o de manchas de vegetação (patches) e a relação entre estas e a matriz onde estão inseridas. Segundo os autores, o grau de interação entre manchas semelhantes irá depender do tamanho dos fragmentos e da distância entre eles. Ainda segundo os autores a alta porosidade da matriz - número das manchas de vegetação nativa dispersas na matriz - devem ter um maior ou menor efeito nos objetos que se movem através da matriz, dependendo da natureza dos fluxos entre os fragmentos e a matriz.

Viana (1990) conceituou matriz como tipo de vizinhança, afirmando ser este fator de grande importância para os ecossistemas florestais, uma vez que pode funcionar como barreira de animais como a cultura da cana de açúcar, fonte de poluentes e perturbações como aplicação de biocidas em culturas anuais e fogo, e também podem ser fontes de propágulos invasores e causar mudanças climáticas, como é o caso da pastagem.

Hansky \& Simberloff (1997) sugerem que a ecologia de paisagem e a teoria de metapopulações compartilham de um mesmo foco: o espaço e os modelos de manchas (patches). A diferença é que o objeto da ecologia da paisagem é a complexa estrutura de mosaico de uma paisagem real. Em contraste, os estudos de metapopulação assumem que as manchas (fragmentos) utilizadas pelas espécies focais são do mesmo tipo, para que os modelos se tornem razoavelmente simples. Além disto, a ecologia da paisagem procura incorporar os conceitos anteriormente citados e se propõe a trabalhar em uma escala global, considerando o homem como um componente integrante da paisagem.

Jelinsky (1997) sugere que, além dos estudos em escala regional ou em nível de paisagem, deve ser considerada a composição genética das espécies (informação de escala fina) e processos evolucionários (e.g. adaptação, especiação) que dão origem aos níveis maiores de organização bio-espacial (maior escala). 
Para Boyle \& Young (2000) os três principais efeitos da fragmentação sobre as espécies são: redução do número de indivíduos, redução do tamanho médio da população e isolamento das populações remanescentes dentro de uma matriz não florestal. Os resultados genéticos destas mudanças são, principalmente, a perda de diversidade genética na população e, ao nível de espécie, mudança na estrutura interpopulacional e aumento de autofecundação. Ainda segundo os autores, em termos de conservação in situ, a baixa variação genética limita a habilidade da espécie responder às condições ambientais através de seleção, enquanto as mudanças na estrutura interpopulacional podem alterar a escala das respostas ( indivíduo - indivíduo ou população - população), e também afetam a velocidade com que as mutações se expandem. Para a utilização de espécies em escala comercial, uma base genética estreita limita o potencial da espécie para a domesticação e reduz a eficiência dos programas de melhoramento.

Vários autores tem chegado ao consenso de que o isolamento pode trazer diversos problemas para a conservação genética dos recursos florestais. Baundry (1989), argumenta que a fragmentação de ecossistemas florestais não é apenas um fenômeno biológico, mas está diretamente ligada com a dinâmica de uso da terra em áreas urbanas e rurais. Uma das principais conseqüências da fragmentação é a perda da biodiversidade pois, à medida que as populações de plantas e animais se tornam menores e isoladas, têm maior chance de extinção em função da depressão endogâmica e baixa resistência a eventos catastróficos (Viana, 1995).

De acordo com Barret \& Kohn (1991), a perda de variação alélica implica na redução da habilidade das populações de se adaptarem às mudanças ambientais, assim como no aumento da suscetibilidade por parte dessas populações às pestes e doenças. Ballal et al. (1994) explicam que a grande conseqüência deste processo é que as espécies têm sua sobrevivência comprometida devido às alterações nos padrões de troca de genes.

Segundo Souza (1997), a fragmentação de habitats também pode colaborar para modificações no sistema de cruzamento, alterando a composição dos agentes polinizadores ou mesmo em seus comportamentos individuais. Sendo assim, estas mudanças podem se refletir nos parâmetros relativos ao sistema de cruzamento. Ainda, 
segundo Foré et al. (1992), a fragmentação florestal pode modificar os padrões de dispersão de pólen e sementes, alterando a diversidade genética e a estrutura.

\subsection{Estrutura Genética de Populações e Conservação in situ}

Segundo Martins (1995), a floresta tropical úmida é, sem dúvida, o ecossistema de maior diversidade de espécies e complexidade de relações ecológicas, sendo um modelo de dificuldade quanto ao seu entendimento e, portanto, quanto à sua conservação in situ. Loveless \& Hamrick (1984), afirmam que estudar a estrutura genética das populações de uma espécie implica em se caracterizar como é distribuída a variação entre e dentro das populações, ou entre subdivisões dentro da mesma população.

A distribuição dos genótipos e alelos não é aleatória e sim resultado da ação de forças evolutivas como seleção, mutação e deriva, que tendem a produzir a diferenciação genética e a migração, responsável pela homogeneização genética (Loveless \& Hamrick, 1984). A importância relativa destes fatores diferem entre as espécies e grupos ecológicos. Onde as populações são pequenas e isoladas, a deriva genética terá influência dominante na estrutura genética da população (Barret \& Kohn, 1991). O processo de deriva genética aleatória pode ser encarado como uma flutuação aleatória na freqüência alélica, levando, eventualmente, à fixação ou à perda do alelo. Este processo ocorre em toda população finita, mas é tanto mais rápido quanto menor a população. A deriva genética apresenta numerosas conseqüências evolutivas, das quais merecem ênfase especial: perda de variação genética dentro das populações e na divergência genética entre elas, inteiramente ao acaso (Futuyma, 1992).

Ainda segundo Barret \& Kohn (1991), o tamanho da população é também um fator importante para a conservação genética. Não deve ser o número de indivíduos da população e sim o número que, efetivamente, realiza trocas gênicas, pois esse número é geralmente diferente do tamanho da população; isso ocorre por diversos fatores, tais como flutuações temporais no número de indivíduos, cruzamentos direcionados, diferenciais de fertilidade e fluxo gênico entre populações. Para Frankel \& Soulé (1983), manter o maior tamanho da população é de vital importância para minimizar os riscos de 
extinção da mesma. Frankel e Soulé, citados por Kageyama (1987), levantam o porque da necessidade de evoluir: o ambiente biótico para todas as espécies está em contínua mudança, adaptando-se ao regime de seleção para seus predadores, hospedeiros, simbiontes e competidores, necessitando as espécies de um potencial de variabilidade nas populações para continuidade da evolução.

Como resultado da restrição temporária de tamanho da população, pode-se ter o fenômeno de gargalo genético (bottleneck). De acordo com Barret \& Kohn (1991), o gargalo ocorre como resultado de alguma catástrofe ambiental e se refere ao colapso no número de indivíduos de uma população. O gargalo está associado com eventos de colonização, ou seja, se um ou poucos indivíduos estabelecem populações em um território previamente desocupado. Segundo Maruyama \& Fuerst (1984), estudos sobre gargalos podem ter aplicações práticas para a conservação dos recursos genéticos de plantas cultivadas, animais e espécies ameaçadas.

De acordo com Cornuet \& Luikart (1996), o entendimento dos efeitos que o gargalo tem na variação genética tem se tornado importante no estudo genético das populações, teoria sobre especiação e conservação biológica. Conservacionistas concordam que o gargalo deve ser evitado para espécies ameaçadas porque ele pode aumentar as taxas de autofecundação, a perda de variação genética e levar à fixação gradual de alelos deletérios e, deste modo, reduzir o potencial adaptativo e aumentar a probabilidade de extinção.

Outro fator importante para populações está relacionado ao tamanho populacional pequeno durante a colonização: o efeito do fundador. Este termo foi criado por Mayr, citado por Barret \& Kohn (1991), para se referir ao estabelecimento de uma nova população através de poucos fundadores, que carregam apenas uma pequena fração da variação genética da população parental. Segundo Futuyma (1992), se uma parte do habitat é colonizado por poucos indivíduos de uma determinada espécie, todos os genes da população originada terão derivado daqueles portados pelos fundadores e de mutações e imigrantes subsequentes. A riqueza alélica da população pode ser menor que a da população fundadora, mas a heterozigosidade pode ser alta, dependendo dos organismos fundadores (ploidia). Entretanto se a colônia permanecer pequena, a 
heterozigosidade da colônia diminuirá rapidamente por deriva mas, se a colônia crescer rapidamente não haverá grande redução na quantidade de variação genética.

Foram elaborados dois modelos para discutir o efeito da extinção local e recolonização para espécies pioneiras. De acordo com Wright (1940) as espécies pioneiras deveriam claramente mostrar sub estruturação na população devido ao pequeno número de indivíduos colonizadores, sofrendo portanto o efeito do fundador. Contudo Slatkin (1987) usou o modelo tipo ilha para mostrar que a extinção e recolonização pode aumentar o fluxo gênico e reduzir a diferenciação entre as populações.

Segundo Futuyama (1992) existem quatro modelos para explicar o fluxo gênico entre populações: o modelo continente-ilha, em que fluxo de alelos ocorre em uma única direção, partindo de uma população grande para uma população menor e isolada; o modelo de ilhas, no qual o movimento de alelos se dá ao acaso, em qualquer direção, entre um grupo de pequenas populações; o modelo de alpondras (stepping stones), onde o fluxo ocorre apenas entre populações vizinhas; e o modelo de isolamento por distância, no qual o fluxo gênico ocorre localmente entre os vizinhos, em uma população de distribuição contínua. O autor considera ainda que, independente do modelo utilizado, o fluxo gênico tem o efeito de homogeneizar a composição genética. Se, de todas as subpopulações que formam a população maior (Metapopulação) chegarem migrantes ao acaso, mesmo uma pequena quantidade de fluxo gênico reduz grandemente a diversidade genética entre as populações causada pela deriva. De acordo com Martins (1995), entre os diversos mecanismos microevolutivos, o fluxo gênico é importante por suas implicações na estrutura genética de populações, tanto entre como dentro das populações, pois condiciona a natureza e o nível de variabilidade dessas populações, e precisa ser considerado no estabelecimento e manejo de reservas genéticas.

O fluxo gênico implica na troca de gametas ou genes entre árvores que estão dispersas na paisagem, e é inversamente relacionado à diferenciação de populações. Ele ocorre através do fluxo de pólen e sementes, que podem ser dispersos por uma ampla variedade de mecanismos vivos ou abióticos. O conhecimento de como as populações 
aumentam, se mantém ou são restritas pelo fluxo gênico é essencial para o manejo distinto de populações de espécies arbóreas em seu ambiente original.

De acordo com Bawa \& Ashton (1991), o problema para a conservação ou manejo da biodiversidade presente nos trópicos é composto pelo grande número de espécies raras, com uma variedade de interações mutualísticas entre plantas e outros organismos e a dificuldade da conservação ex situ. A conservação da diversidade genética das espécies tropicais, sejam elas raras ou comuns, é um desafio e uma tarefa urgente. Isto requer um conhecimento sobre distribuição, abundância de espécies e interações entre organismos chaves.

Kageyama (1987) cita que o método ideal para a conservação a longo prazo é a conservação in situ, de forma que a população em equilíbrio no seu ecossistema continue sua evolução, principalmente para os casos em que toda uma comunidade de espécies está sendo o objetivo da conservação, como por exemplo os programas com espécies florestais tropicais. Segundo Martins (1987) para o estabelecimento e manejo de reservas genéticas, devem ser levadas em consideração tanto a necessidade de variação genética para assegurar evolução contínua, como a ocorrência de certos processos básicos que permitem a reprodução contínua e sobrevivência.

Kageyama et al. (2000) explicam que a grande interação entre plantas e animais e microrganismos, responsável pela alta diversidade das florestas tropicais, tem implicações com a conservação genética in situ, uma vez que estes organismos associados devem também estar presentes e ser considerados nos programas de conservação. Kearns et al. (1998) consideram que a conservação de habitats é uma das soluções potenciais de manejo para a conservação das interações planta-polinizador.

\subsection{Diversidade da Floresta Tropical}

A biodiversidade se refere à variedade natural e variabilidade entre os organismos vivos, o complexo ecológico no qual eles naturalmente ocorrem e as maneiras como eles interagem entre si e com o ambiente físico (OTA,1987; Noss, 1990; Noss e Coperrider,1994 e Sanderson \& Redford, 1997) citados por Redford \& Ritcher, 
1999. Para Noss (1990), melhor do que definir a biodiversidade de maneira vaga é identificar atributos e/ou indicadores mensuráveis de biodiversidade para inventariar, monitorar e elaborar programas de conservação. Redford \& Ritcher (1999), baseados no trabalho citado acima, definiram que a biodiversidade pode ser medida em termos de diferentes componentes: genético, população/espécie e comunidade/ecossistema, sendo que cada componente tem como seus atributos composição, estrutura e função. Esses atributos dos componentes da biodiversidade têm sido utilizados pelo Banco Mundial para selecionar projetos de conservação, a fim de otimizar os recursos empregados.

Entre estes componentes, os mais utilizados para gerar índices de diversidade são em nível de espécie e ecossistema, principalmente relacionados à composição, de maneira que muitas vezes espécies ou ecossistemas são alvo de extensos estudos e nem sempre representam o estado de conservação do bioma. Redford \& Richter (1999) mostram que alguns dos componentes e atributos da biodiversidade são mais sensíveis ao uso humano, como o componente genético.

Este esclarecimento inicial se torna necessário para entendermos em que nível de diversidade estamos trabalhando e que estes resultados são apenas um componente deste complexo de inter-relações, já que tratamos de um bioma tão rico.

A diversidade e a raridade da maioria das espécies são características marcantes das florestas tropicais; porém, segundo Kageyama \& Gandara (2000), a diversidade de espécies na floresta não está igualmente distribuída entre os diferentes tipos de espécies, pois o processo de sucessão secundária é responsável pela contínua mudança na composição florística e estrutural da floresta. Além disto, existem duas situações de sucessão: i) aquela ocorrendo dentro da floresta primária e ii) a que é comum após perturbações em grande escala. A primeira é o processo de auto-renovação pelo qual as florestas passam com a abertura de clareiras naturais e posterior recolonização por espécies de diferentes grupos sucessionais.

Diferentemente da sucessão secundária, em áreas degradadas pela ação antrópica ocorre uma sucessão diferenciada, especialmente quanto à origem das espécies iniciais da sucessão. Para Budowski (1965), pode-se distinguir quatro grupos sucessionais: espécies pioneiras, secundárias iniciais, secundárias tardias e climácicas. No contexto da 
sucessão antrópica, pode-se identificar mais dois grupos de espécies - pioneiras antrópicas: espécies não tipicamente pioneiras na floresta primária mas que fazem o papel de pioneiras em áreas degradadas antrópicas e - secundárias/pioneiras antrópicas: espécies secundárias normalmente raras na floresta primária e que, em áreas degradadas, fazem o papel das pioneiras (Kageyama \& Gandara, 2000).

Kageyama \& Reis (1993) descrevem a Miconia cinnamomifolia e Rapanea ferruginea como pioneiras antrópicas, ocorrentes em florestas secundárias no Vale do Itajaí, colonizando áreas que foram deflorestadas e abandonadas, formando verdadeiros maciços. De acordo com Mantovani et al. (1990) áreas com vegetação secundária caracterizam-se em geral, por uma pequena diversidade de espécies e homogeneidade fisionômica em cada estágio sucessional ou seral. Ainda segundo os autores as formações secundárias tem papel importante no processo de restauração do equilíbrio dos ecossistemas e funcionam como cicatrizantes das áreas de floresta abertas com a queda de árvores ou deslizamentos naturais, promovendo uma proteção mais ou menos eficiente contra diversos processos erosivos.

Tabarelli \& Mantovani (1999 a) encontraram uma maior diversidade e riqueza de espécies em floresta secundária com quarenta anos de idade (Riqueza=90 e Diversidade de Shanon-Weiner=5,274), a qual se compara com uma floresta madura, no Parque Estadual da Serra do Mar, Núcleo Santa Virgínia. Os autores concluíram que fatores históricos e ecológicos afetam a riqueza de espécies na Floresta Atlântica Montana, como localização dos centros de distribuição de gêneros e famílias ricas em espécies pioneiras e diferenças entre exposição solar e relevo montanhoso. Em levantamento realizado por Tabarelli \& Mantovani (1999 b), em clareiras naturais da floresta no Núcleo Santa Virgínia, 49\% do total de espécies e 52\% do total de indivíduos foram constituídos pelas espécies Miconia, Leandra e Rapanea.

De acordo com as proposições de Kageyama \& Reis (1993) populações de espécies colonizadoras como de ambientes perturbados, como Miconia e Rapanea, podem ter sua variabilidade genética aumentada pelas sucessivas recombinações entre indivíduos que vieram de populações anteriormente isoladas, promovendo assim a diminuição da divergência entre as populações. seguindo desta forma a teoria de Slatkin. 
Pode ocorrer também a diminuição na variabilidade da nova população devido a um pequeno número de indivíduos fundadores. Outras espécies descritas como pioneiras antrópicas são a Bauhinia forficata - pata de vaca (Santos,1994) e Piper hispidinervum pimenta longa, sendo esta última considerada até pouco tempo uma praga pelos agricultores no Acre (Wadt, 2000).

Estas áreas de sucessão secundária são bastante interessantes do ponto de vista do manejo, tanto por poder apresentar alta variabilidade genética como também um número significativo de indivíduos adultos por hectare.

O manejo sustentável das florestas naturais depende da sua habilidade de regeneração. O sucesso da regeneração de florestas acompanhada pela conservação genética das espécies é importante tanto para adaptação a curto tempo a mudanças ambientais e efeitos nas espécies e comunidades à longo prazo (Templeton, 1995).

Segundo Yeh (1989), a capacidade de regeneração e diversidade genética seriam dois pontos importantes para o desenvolvimento de um guia do manejo florestal sustentável e estratégias efetivas de conservação. Ainda, segundo o autor, a estimativa de diversidade genética de espécies florestais pode ser rapidamente feita usando marcadores isoenzimáticos.

\subsection{Uso de Marcadores Genéticos}

Marcadores genéticos têm diversas aplicações na conservação genética dos recursos florestais, descritas por Glaubitz \& Moram (2000): mensuração da diversidade genética e diferenciação em populações naturais e manejadas, estimativas das taxas de fluxo gênico ou migração, caracterização do sistema de cruzamento, análise de paternidade, avaliação da eficiência do pomar de sementes, estudo de filogenia e taxonomia e quantificação e mapeamento de ligações genéticas. De acordo com Alfenas (1991), podem ser divididos em três classes: marcadores morfológicos, marcadores bioquímicos (técnica de isoenzimas) e marcadores baseados no DNA. A eletroforese de isoenzimas consiste na migração de moléculas ionizadas, de acordo com suas cargas 
elétricas e pesos moleculares, em um campo elétrico (Negrão,1999). Na eletroforese as enzimas são separadas em função de sua variável composição de aminoácidos.

Para Alfenas (1991), as isoenzimas/aloenzimas apresentam vantagens em relação a outros marcadores pois: a) permitem a análise de vários locos simultaneamente, b) os alelos de cada loco são codominantes, permitindo a identificação de heterozigotos, c) medem a variabilidade a um nível mais próximo do DNA do que outras características fenotípicas, pois constituem um produto direto da ação gênica.

De acordo com o referido autor, apesar das isoenzimas não revelarem toda a variação genética, elas têm vantagens tanto econômicas como de rápida execução para estudos em nível populacional, se comparadas a outras técnicas. $\mathrm{Na}$ área florestal, as isoenzimas têm sido empregadas como marcadores genéticos para determinar, entre outros: a) a identidade de plantas parentais em cruzamentos e clones, b) nível de autogamia, c) a contaminação por pólen estranho, d) o sistema de cruzamento, e) as ligações gênicas e o nível de heterozigose e f) diversidade genética dentro e entre populações naturais.

A principal limitação da técnica de isoenzimas é o número pequeno de locos acessíveis e a variação da expressão das isoenzimas de acordo com o tecido da planta. Muitos locos têm expressão em plântulas, e não em outros tecidos da planta. $\mathrm{O}$ grau de polimorfismo é geralmente de baixo a moderado, enquanto em outras técnicas, como microsatélites, é alto.

\subsection{A Espécie}

\subsubsection{Ocorrência}

A espécie Miconia cinnamomifolia, comumente conhecida como jacatirão ou jacatirão-açu no Estado de São Paulo, pertence à família Melastomataceae e tem ocorrência descrita por Lorenzi (1994) entre os Estados da Bahia até Santa Catarina. Klein (1979) descreve a Miconia como espécie exclusiva e característica da encosta atlântica, muito freqüente no Baixo e Médio Vale do Itajaí, ocorrendo desde o Espirito 
Santo, Rio de Janeiro, Minas Gerais, São Paulo, Paraná e Santa Catarina, onde o autor observou suas formações contínuas em dossel e denominou como Miconietum. Segundo Carvalho (1994), a Miconia cinnamomifolia ocorre em associações mais evoluídas da vegetação secundária: capoeirões e florestas secundárias situadas nas encostas enxutas e íngremes, em altitudes de até $200 \mathrm{~m}$.

\subsubsection{Descrição morfológica}

Wurdack (1962) descreve o jacatirão para a flora de Santa Catariana: a espécie apresenta os ramos jovens compridos e quadrangulares, com estipulas interpeciolares localizadas nos nós. A lâmina foliar apresenta dimensões entre $6-10$ × 2,5-5 cm, com formato oblongo-ovada, de textura coriácea, 3-5 subnervada. Apresenta flores pentâmeras curtamente pediceladas, com pétalas entre 2 a $1,5 \mathrm{~mm}$, oblongo-obovadas e anteras com $1,5 \mathrm{~mm}$ de comprimento com poro largo. O ovário é trilocular, $1 / 2$ inferior, glabro. $\mathrm{O}$ fruto é bacídio globoso, que na maturação vai de verde (de consistência rígida) ao atro-púrpureo (de consistência muito macia), passando por verde-amarelado e verdeazulado. As sementes são trifacetadas, de coloração pardo amarelada, com mácula negra em uma das faces.

\subsubsection{Fenologia e dinâmica sucessional}

Pereira (1998) realizou o acompanhamento fenológico da espécie e observou que a florada tem início em outubro/novembro e se estende até o final de dezembro ou meados de janeiro. A frutificação é longa e heterogênea e a ocorrência de frutos maduros foi observada desde janeiro/fevereiro até julho/agosto. De acordo com Queiroz (1982) o jacatirão tem sementes fotoblásticas positivas e formam banco de sementes no solo, evidenciando características de espécie pioneira, mas que, por outro lado, tem crescimento lento e longevidade superior às espécies tipicamente pioneiras.

Pereira (1998) justifica que a capacidade da espécie fornecer alimento está intimamente relacionada ao seu estabelecimento e distribuição, pois foram observadas 
várias síndromes de dispersão, como barocoria e por zoocoria garantindo que a espécies se estabeleça tanto em sítios próximos, como em sítios muito distantes. Em seu trabalho, realizado na Reserva Biológica de Poço das Antas, foram observadas algumas aves alimentando-se de frutos de jacatirão: Pipra pipra (cabeça branca), Pipra rubrocapilla (cabeça encarnada), Machaeropterus regulus (tangará rajado), Megarhynchus pitangua (Bem-te-vi-de-bico-chato), Cnemotriccus fuscatus (Guaracavuçu), Capsiempis flaveola (Marianainha-amarela), Turdus amaurochalinus (Sabiapoca), Viero oivaceus (Juruviara), Cacicus haemorrhous (Guaxe), Conirostrum speciosum (Figurinha de rabo castanho), Tangara mexicana (coleiro-de-banho) Ramphocelus bresilus (Tiê sangue) Tachyphonus cristatus (Tiê-galo), Saltator maximus (tempera-viola). Anteriormente Gilbert (1980) sugeriu o termo mutualista chave para enfocar que as Melastomataceas são um grupo fundamental para manter a diversidade de aves frugívoras em florestas tropicais.

\subsubsection{Importância e utilidade}

Pode ser utilizada como madeira serrada e roliça para suporte de lajes e alinhamento, carpintaria, tabuado em geral, obras internas; mourões de cerca, dormentes, postes e laminação. A madeira é também potencialmente apta para a conversão em carvão vegetal e lenha. No Estado de Santa Catarina a tinta preta extraída da casca do jacatirão era utilizada para tingir redes de pesca. É recomendada para reflorestamento ambiental (Carvalho,1994). O viveiro da CESP Paraíbuna tem produzido mudas de jacatirão para plantio de recuperação de áreas, utilizando modelos sucessionais, em que o jacatirão é plantado como espécie pioneira.

O jacatirão serve bem como espécie representativa da condição de sucessão secundária a partir da intervenção antrópica, no caso, extração seletiva de madeira na Mata Atlântica: sob condição antropizada forma maciços de indivíduos e, na floresta primária é uma espécie relativamente rara. Por apresentar alta densidade de indivíduos e ter importância madeireira, a exploração do jacatirão está regulamentada em caráter emergencial e temporária na Região do Vale do Ribeira e Litoral Sul do Estado de São 
Paulo pela resolução SMA no. 46, de Setembro de 1995, em observância à Lei 4771/65 e ao Decreto 750/93, que permite a exploração seletiva de determinadas espécies nativas em áreas cobertas por vegetação primária ou nos estágios avançado e médio de regeneração.

De acordo com Carvalho (1994) a espécie manejada em regeneração natural apresentou um incremento volumétrico de $14 \mathrm{~m}^{3} /$ ha.ano com casca. Estima-se uma rotação de 10 a 15 anos para a produção de lenha e 20 anos para uso industrial, com bitola de 40 a $60 \mathrm{~cm}$ (Fischer,1973). Segundo o autor a espécie tem boa estabilidade física, o que faz com que seja procurada para a construção civil, e também apresenta boa durabilidade natural, embora não seja resistente à umidade e ao ataque de cupins. Sua madeira apresenta massa específica aparente de 0,7 a $0,76 \mathrm{~g} / \mathrm{cm}^{3}$ a $12 \%$ de umidade (Paraná, 1979). 


\section{MATERIAL E MÉTODOS}

\subsection{Localização}

A área de estudo localiza-se no município de Biritiba Mirim, entre as cidades de Mogi das Cruzes e Salesopolis (Figura 1).

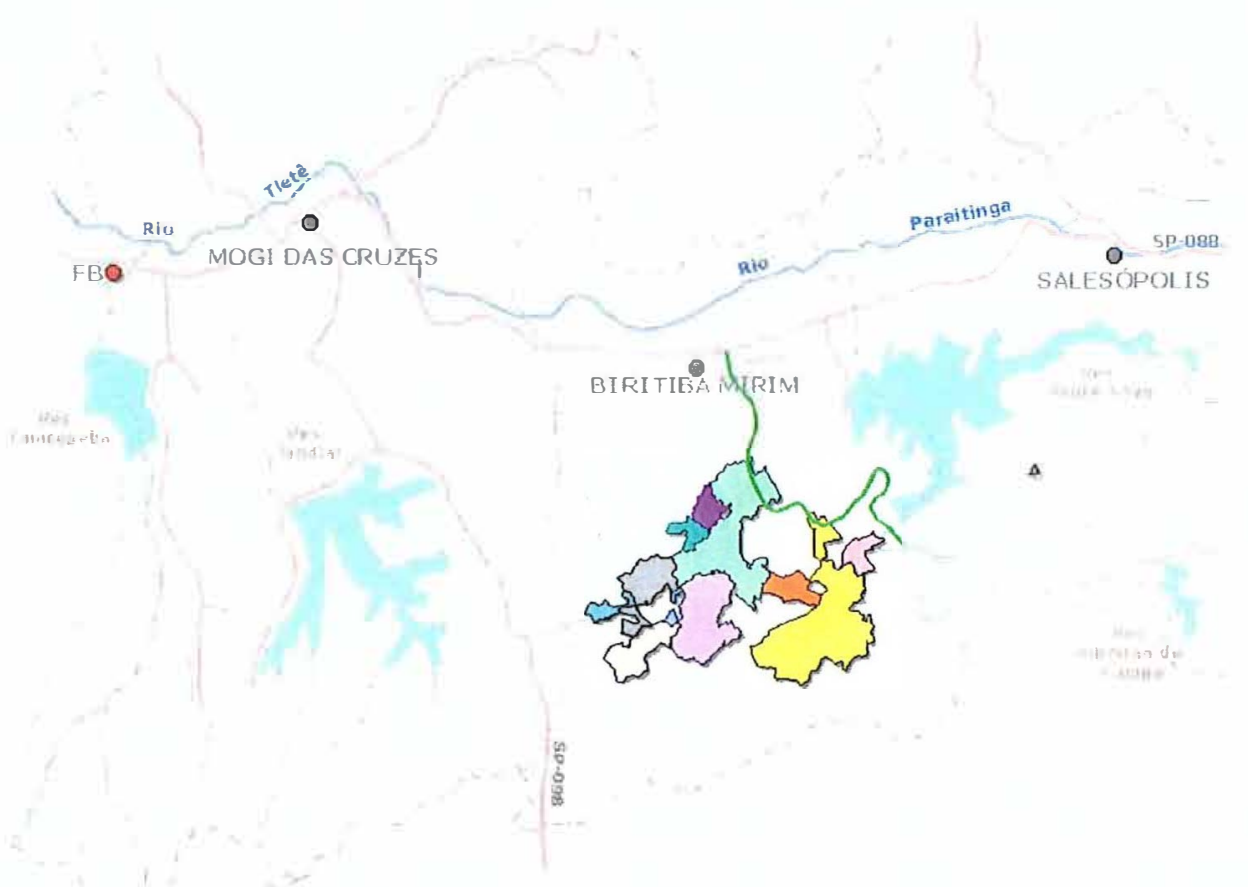

Figura 1 - Localização da área de estudo: Biritiba Mirim, SP. 


\subsection{Clima}

A região apresenta clima dos tipos Cfb e Cwb, de Koeppen (Setzer, 1946), que caracteriza-se por temperaturas médias anuais em torno de $22{ }^{\circ} \mathrm{C}\left(15{ }^{\circ} \mathrm{C}\right.$ na estação subseca e $25{ }^{\circ} \mathrm{C}$ na estação úmida) com mínima registrada de $2{ }^{\circ} \mathrm{C}$ e máxima de $32{ }^{\circ} \mathrm{C}$.

De acordo com o Atlas Pluviométrico do Estado de São Paulo (1972), a pluviosidade anual média está em torno de $1801 \mathrm{~mm}$ sendo os meses mais chuvosos dezembro, janeiro e fevereiro, com pluviosidade média em torno de $242 \mathrm{~mm}$ e os meses mais secos ( maio, junho, julho, agosto e setembro) com pluviosidade média em torno de $76 \mathrm{~mm}$.

\subsection{Vegetação}

As áreas onde foram realizadas as amostragens são tipicamente compostas por vegetação secundária madura da Floresta Ombrófila Densa Montana de acordo com Veloso et al.(1991), domínio da Mata Atlântica, com alta riqueza florística, apresentando cerca de 3 estratos bem definidos: i) sub bosque, composto por espécies como palmito, Eugenia e bromélias ii) dossel, com altura média de $20 \mathrm{~m}$, praticamente ocupado por Miconia cinnamomifolia, Miconia cabuçu, Eriotheca candolleana e outras espécies descritas na Tabela 3, iii) e um estrato ocupado por poucas árvores emergentes, como Cedrela fissilis e Aspidosperma polyneuron.

\subsection{Metodologia}

\subsubsection{Levantamento do histórico}

A caracterização foi feita com base em ortofotocartas (escala 1:10.000), data do vôo 07/89, execução da AERODATA, contratada pela Companhia Suzano de Papel e Celulose e por fotos aéreas dos anos de 62 e 72, executadas pela empresas: VASP aerofotogrametria S/A e Aerofoto Natividade Ltda, respectivamente. Além das fotos, foram também utilizadas plantas altimétricas (escala 1:13.000), data de 1999, execução 
da AERODATA, cedidas pela Companhia Suzano de papel e Celulose e, mapas de Mogi das Cruzes e Salesópolis.

Através destes recursos, foi possível identificar as formações existentes no mosaico que circunda o fragmento, além de medir a distância entre as duas subpopulações amostradas e a distância média entre o fragmento e a Serra do Mar, bem como avaliar a dinâmica de ocupação da paisagem ao longo de 40 anos.

Foram realizadas também entrevistas com os funcionários mais antigos da Fazenda Itapanhaú e moradores de Biritiba Mirim para a verificação dos fenômenos econômicos que contextualizaram as mudanças ocorridas neste trecho da Mata Atlântica. Segundo Marccucci (1999), o levantamento destas informações culturais e econômicas são de extrema importância para o planejamento futuro da paisagem.

\subsubsection{Amostragem e coleta do material vegetativo}

Para a amostragem das subpopulações de Miconia cinnamomifolia foram abertos 4 transectos paralelos com $20 \mathrm{~m}$ de largura e $200 \mathrm{~m}$ de comprimento e mapeados 50 indivíduos adultos da espécie em cada uma para posterior coleta de folhas (Figuras 2 e3). De acordo com Sebbenn (2001), o tamanho ideal para a avaliação de indivíduos adultos, em uma ou várias populações, com base em medidas probabilísticas, está entre 60 a 100 indivíduos. Já para uma população estruturada em progênies, quando a espécie for alógama ou reprodução mista deve ser feita a amostragem de 30 progênies com 10 plantas por progênie.

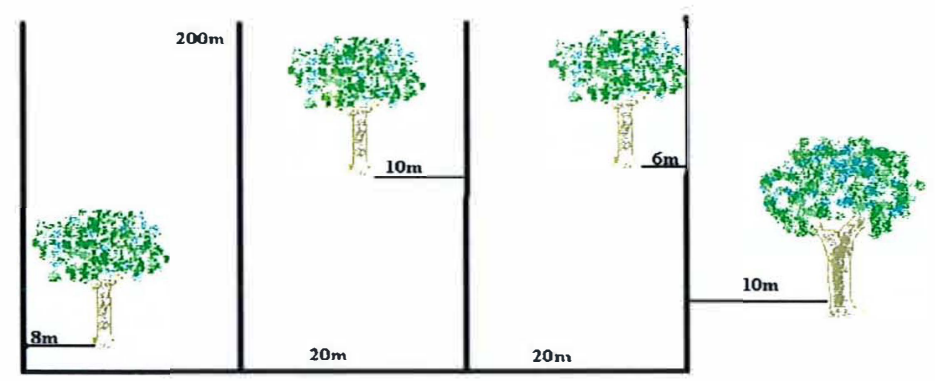

Figura 2 - Esquema do transecto aberto para a realização da amostragem. 


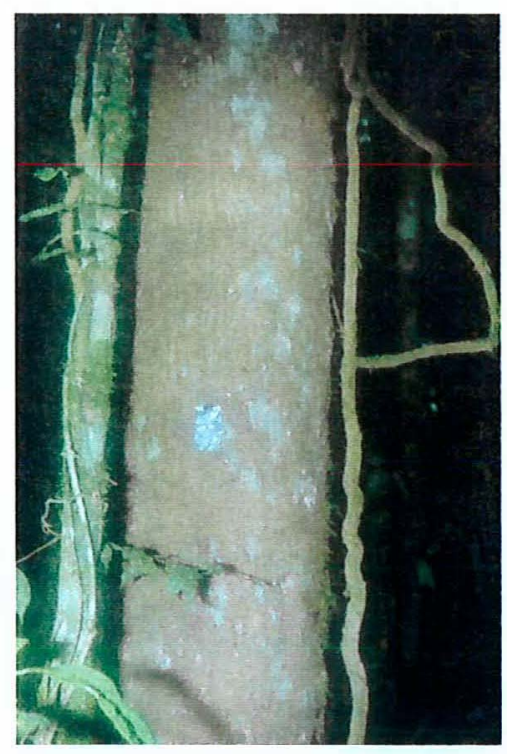

Figura 3 - Tronco do jacatirão com etiqueta.

Foram estabelecidos também dois transectos de cerca de $800 \mathrm{~m}$ de comprimento partindo das duas subpopulações, totalizando $1600 \mathrm{~m}$ entre as áreas amostradas, para averiguação da descontinuidade das subpopulações.

\subsubsection{Desenvolvimento do protocolo}

Foi desenvolvido o protocolo de análise eletroforética de isoenzimas para a $M$. cinnamomifolia pois não existia, até o presente momento, nenhum estudo neste sentido. Para a posterior análise de variabilidade genética de populações, essa etapa é de extrema importância na busca por sistemas enzimáticos que apresentem atividade e tenham boa resolução após a revelação. Para tanto, a extração das enzimas foi feita através da maceração de aproximadamente $2 \mathrm{~g}$ de folhas colhidas e armazenadas em geladeira em sacos de papel e sacos plásticos durante dois dias, utilizando-se a solução 1 de Alfenas (1991), como é mostrado na Tabela 1. 
Tabelal. Composição da solução utilizada na extração de enzimas, conforme Alfenas (1991).

\begin{tabular}{lc}
\hline \multicolumn{1}{c}{ Reagente } & Quantidade \\
\hline Fosfato de sódio dibásico & $0.6 \mathrm{~g}$ \\
Sacarose & $7 \mathrm{~g}$ \\
Polivinil pirolidona PVP-40 & $2.56 \mathrm{~g}$ \\
L-ácido ascórbico & $100 \mathrm{mg}$ \\
Dietilditiocarbamato DIECA & $100 \mathrm{mg}$ \\
Bissulfito de sódio & $50 \mathrm{mg}$ \\
Borato de sódio & $50 \mathrm{mg}$ \\
Polietilenoglicol -6000 & $1 \mathrm{~g}$ \\
Mercaptoetanol & $1-2 \mathrm{ml}$ \\
Água destilada (q.s.p.) & $100 \mathrm{ml}$ \\
\hline
\end{tabular}

Após a extração, pequenos wicks (papel whatmam n ${ }^{0} 3$ ) com dimensões de $0,5 \mathrm{x}$ $1,5 \mathrm{~cm}$ foram embebidos nos extratos obtidos e armazenados em freezer $-80{ }^{\circ} \mathrm{C}$, até o momento da realização da corrida eletroforética. Foram testados quatro sistemas tampão gel/eletrodo: Citrato Morfolina (CM), Histidina (25), o Lítio/Borato (19) e Tris Citrato ( $\mathrm{TC})$.

Foram realizadas corridas para o teste de 31 sistemas de coloração descritos na Tabela 2, para os dois primeiros sistemas de gel/eletrodo. As enzimas que obtiveram boa atividade nestes dois sistemas foram utilizadas para os outros dois últimos sistemas de corrida com o intuito de obter uma melhor resolução. 
Tabela 2. Enzimas testadas e seus respectivos códigos Alfenas (1991).

\begin{tabular}{ll}
\hline \multicolumn{1}{c}{ Enzima } & \multicolumn{1}{c}{ Código } \\
\hline 1. Esterase & Q EST - EC. 3.1.1.1 \\
2. Malato Desidrogenase & MDH - EC 1.1.1.37 \\
3. Polifenoloxidase & PPO - EC 1.14.18.1 \\
4. $\beta$ - Glucosidade & B- GLU - EC 3.2.1.21 \\
5. Fumarase & FUM - EC 4.2.1.2 \\
6. Galactose desidrogenase & GLDH - EC 1.1.1.48 \\
7. Alanina desidrogenase & ALDH - EC 1.4.1.1 \\
8. 6-fosfogluconato desidrogenase & 6PGDH - EC \\
9. Leucina aminopeptidase & LAP - EC 3.4.11.1 \\
10. Menadinona redutase & MR - EC 1.6.99.3 \\
11. 6-fosfogluconato desidrogenase * & PGDH \\
12. Fosfatase ácida & ACP - EC 3.1.3.2 \\
13. Glutamato desidrogenase & GDH - EC 1.4.1.3 \\
14. Isocitrato desidrogenase & IDH - EC 1.1.1.42 \\
15. Fosfoglucose isomerase & PGI - EC 5.3.1.9 \\
16. Lactato desidrogenase & LDH - EC 1.1.1.27 \\
17. Glucose-6-fosfato desidrogenase & G6PDH - EC 1.1.1.44 \\
18. Álcool desidrogenase & ADH - EC 1.1.1.1 \\
19. Nicotinamida adenina dinucleotídeo & NADHDH - EC 1.6.99.3 \\
20. Glutamato-oxaloacetato transamitase & GOT - EC 2.6.1.1 \\
21. Aldolase & ALD - EC 4.1.2.13 \\
22. Diaforase & DIA - EC 1.6.4.3 \\
23. Peroxidase & PO - EC 1.11.1.7 \\
24. Fosfoglucomutase & PGM - EC 2.7.5.1 \\
25. Xiquimato desidrogenase & SKDH - EC 1.1.1.25 \\
26. Enzima málica & ME - EC 1.1.1.40 \\
27. Sorbitol desidrogenase & SDH - EC 1.1.1.14 \\
28. Fosfatase alcalina & ALP - EC 3.3.3.1 \\
29. Superóxido dismutase & SOD - EC 1.15.1.1 \\
30. Endopeptidase & ENP - EC 3.2. \\
31. Manitol desidrogenase & MADH - EC 1.1.1.67 \\
* Receita modificada & \\
&
\end{tabular}

A corrida de eletroforese foi feita em gel horizontal de amido de milho (penetrose) e amido de batata (SIGMA), a 13\% de amido, sendo que cada gel acondicionou 20 amostras e 3 wicks com solução marcadora azul de bromofenol, para indicação do comprimento de migração. 


\subsubsection{Variabilidade genética: Análise estatística}

Uma maneira de se medir a variação genética é utilizar a variação alélica em locos estruturais, utilizando as seguintes estimativas: proporção de locos polimórficos $(\hat{P})$, número médio de alelos por loco $(\hat{A})$, heterozigosidade média observada $\left(\hat{H}_{0}\right)$, heterozigosidade média esperada ou diversidade gênica $\left(\hat{H}_{e}\right)$.

\section{Freqüências alélicas}

As freqüências alélicas foram estimadas pelo programa BIOSYS-2 (Swofford \& Sellander, 1997) e GDA, utilizando a seguinte expressão:

$\hat{p}_{i j}=n_{i j} / n_{. j}$

onde:

$\hat{p}_{i j}=$ estimativa da freqüência do alelo $i$ na população $j$;

$\boldsymbol{n}_{i j}=$ número de ocorrências do alelo i na amostra da população $j$;

$\boldsymbol{n}_{\cdot j}=$ número total de alelos encontrados na amostra da população $j$.

Para alelos codominantes, tais quais os encontrados em isoenzimas, quando todos os genótipos são identificáveis, as frequiências gênicas podem ser estimadas contando-se o número de vezes que cada alelo é encontrado, dividindo-se pelo número total de genes na amostra (Nei, 1987).

\section{Proporção de locos polimórficos $(\hat{P})$}

A proporção de locos polimórficos $(\hat{P})$ foi obtida considerando-se os locos que apresentaram a freqüência igual ou menor do que $95 \%$ do alelo mais freqüente. Segundo Brown \& Weir, citado por Lepch-Cunha (1996), esta estatística combina dois conceitos de diversidade (riqueza e equitabilidade), sem focalizar nenhum dos dois propriamente 
dito. Decorrente disto, existe uma série de problemas como a própria definição de polimorfismo, a dependência do tamanho amostral e o número e tipo de enzimas incluídas na pesquisa. Mesmo assim, é uma medida bastante interessante de se avaliar a variabilidade dentro das populações (Lepch-Cunha,1996).

\section{Número médio de alelos por loco $(\hat{A})$}

O número médio de alelos por loco exprime a riqueza alélica presente na população. De acordo com Nei (1987) esta estatística tem um problema por depender do tamanho amostral, a não ser que este seja mais ou menos o mesmo para todas as amostras. Isto ocorre porque existem muitos alelos de baixa frequiência em populações naturais.

Segundo Murawski \& Bawa (1994), o número efetivo de alelos por loco representa o número necessário dentro de um loco para manter o nível atual de heterozigosidade. É calculado para cada loco pela seguinte fórmula:

$$
\mathrm{Ae}=\frac{1}{\Sigma \mathrm{p}_{i}^{2}} \text { onde: }
$$

$\mathrm{p}_{i}=$ freqüência alélica de cada loco $i$

Quando todos os locos utilizados na análise são polimórficos os índices $\hat{A}$ e $A_{e}$ são iguais.

\section{Heterozigosidade observada $\left(\hat{H}_{o}\right)$}

A heterozigosidade média observada $\left(\hat{H}_{o}\right)$ foi obtida pela média do número de genótipos heterozigotos em relação ao total de genótipos em cada loco e para as médias dos locos de acordo com a equação abaixo:

$$
\begin{aligned}
& \hat{H}_{o}=1-\sum_{i} \hat{p} i i \\
& \widetilde{H}_{o}=\frac{1}{m} \sum^{m} \widetilde{H} \text { onde: }
\end{aligned}
$$


$m=$ número de locos

Heterozigosidade média esperada $\left(\hat{H}_{e}\right)$

De acordo com Nei (1987) a diversidade gênica é a medida mais apropriada da variação gênica, pois pode ser definida em termos de freqüências gênicas. A heterozigosidade esperada $\left(\hat{H}_{e}\right)$ foi estimada pela média das $\hat{H}_{e}$ nos locos de acordo com a seguinte expressão:

$\hat{H}_{e}=1-\sum_{i=1}^{k} \tilde{p}_{i}^{2}$

$\hat{H}_{e}=1-\sum_{i} \sum_{j}^{m} p^{2}{ }_{j j} / m$

onde:

$\mathbf{n}=$ número de indivíduos

$\mathbf{p}_{i}=$ frequência do iésimo alelo.

\section{Estrutura genética}

A análise de estrutura genética foi realizada pelo programa GDA desenvolvido por Lewis \& Zaykin. Foram obtidas as estimativas da distância genética entre as subpopulações $\left(\hat{\theta}_{p}\right)$ e as correlações entre os alelos dentro dos indivíduos das diferentes $\operatorname{subpopulações~}(\hat{f})$ e da população total $(\hat{F})$.

O Intervalo de Confiança a $95 \%$ de probabilidade foi estimado utilizando-se o método de reamostragem "bootstrap", com 10.000 repetições sobre os locos.

Teste para verificação de ajuste ao modelo de Hardy-Weinberg e de Endogamia de Wright - Índice de fixação $(\hat{f})$ 
Este índice mede a fração de redução na heterozigosidade com relação ao esperado em uma população de acasalamentos aleatórios, conforme as expectativas do Equilíbrio de Hardy-Weinberg (Lepch-Cunha, 1996). Quanto mais próximos de zero os índices, maior é a panmixia, ou seja, a população está em EHW.

Os índices de fixação $\hat{f}$ foram obtidos pela seguinte expressão:

$\hat{f}=\frac{\left(\hat{H}_{e}-\hat{H}_{o}\right)}{\hat{H}_{e}}$ onde:

$\hat{H}_{c}$ : freqüência esperada de homozigotos

$\hat{H}_{0}$ : freqüência observada do homozigotos

Foi realizado o teste exato de Fischer para verificar se os dados das subpopulações se adequavam às proporções do Equilíbrio de Hardy-Weinberg.

\section{Taxa de cruzamento aparente $\left(\hat{t}_{a}\right)$}

Para o cálculo da taxa de cruzamento, utilizou-se a seguinte expressão:

$\hat{t}_{a}=\frac{(1+\hat{f})}{(1-\hat{f})}$, Vencovsky (1994)

$\hat{f}=$ coeficiente de endogamia intrapopulacional

\section{Tamanho efetivo $\left(\hat{N}_{e}\right)$}

Para o cálculo do tamanho efetivo populacional $\left(\hat{N}_{e}\right)$ utilizou-se a seguinte expressão:

$\hat{N}_{e}=n /(1+\hat{f})$ (Vencovsky, 1997)

$n=$ número de indivíduos adultos amostrados 
$\hat{f}=$ coeficiente de endogamia intrapopulacional

\section{Autocorrelação espacial}

Para a computação dos dados utilizou-se o programa "Spacial Autocorrelation Analysis Program" (SAAP) versão 4.3, desenvolvido por Wartenberg, que calcula o Índice de Moran para dez classes de distância para cada alelo, quantificando a similaridade genética de pares de indivíduos adjacentes em relação à amostra da população como um todo, pela seguinte expressão:

$$
\hat{I}=(n / m)\left[\sum_{i} \sum_{j}\left(p_{i}-\bar{p}\right)\left(p_{j}-\bar{p}\right) w_{i j} / \sum_{j}\left(p_{i}-\bar{p}\right)^{2}\right]
$$

onde:

$\hat{I}=$ Índice de Moran, que pode assumir valores entre $-1,0$ (autocorrelação negativa) e $+1,0$ (autocorrelação positiva).

$n=$ número de indivíduos analisados

$\mathrm{p}_{i}$ e $\mathrm{p}_{j}=$ freqüência alélica nos indivíduos $i$ e $j$

$\mathrm{p}=$ média de $p$

$w_{i j}=$ elemento da matriz quadrada e simétrica de dimensões $\mathrm{n} \times \mathrm{n}$, ao qual é dado o valor 1 para indivíduos vizinhos e 0 nos outros casos.

$w$ matriz que expressa a relação espacial entre os $\mathrm{n}$ indivíduos e cuja soma, ao longo de $i$ e $j$, é igual ao valor de $w$

A metodologia empregada foi a de agrupamento em classes de distância e os dados obtidos foram plotados em gráficos (correlogramas). 


\section{RESULTADOS E DISCUSSÃO}

\subsection{Histórico da fragmentação do local de estudo}

O fragmento onde foi realizado o presente estudo pertence ao Sr. Vicente de Luca, divisa com a Fazenda Itapanhaú, Companhia Suzano Papel e Celulose.

Através de fotos aéreas e mapas obtidos junto ao setor de cartografia da Companhia Suzano e ao IAC, foi possível delimitar a área e forma do fragmento, bem como os padrões de vizinhança para três diferentes estágios de ocupação da região: década de 60 , década de 70 e final da década de 80 . Além disso, mediu-se a distância entre as duas subpopulações amostradas.

Pela análise das fotos aéreas foi possível verificar que, na década de 60 , mais precisamente no ano de 1962, ocorreu o início da abertura das terras na face leste do fragmento para o plantio da cultura do eucalipto, como é possivel se observar na Figura 4, uma grande porção das áreas aparece de tonalidade clara, indicando descobrimento do solo, ou seja, terra nua. O que se pode perceber é que a abertura propiciou a formação de um corredor de aproximadamente 1,5 a $2 \mathrm{~km}$ de largura, separando o fragmento da Serra do Juqueriquerê. Não foi possível contudo constatar o que existia anteriormente neste corredor, ou seja, se o fragmento fazia parte da Serra do Mar ou se já estava desligado e o que existia era outra cultura. Apesar disto, neste período havia uma ligação entre o fragmento e a Serra do Mar através de uma área não atingida pelo avanço da abertura de terras. 


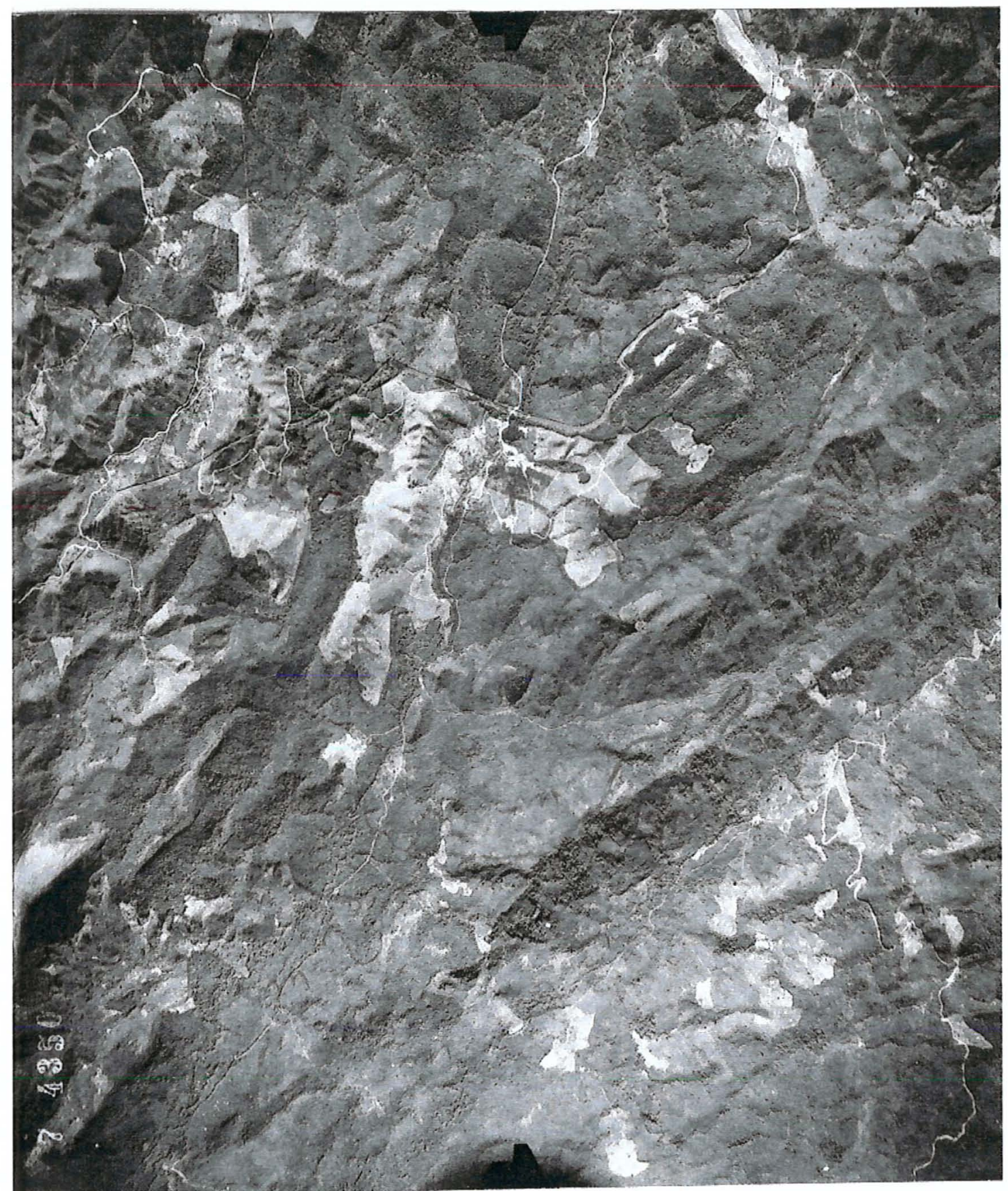

Figura 4 - Abertura das terras para plantio e limite inferior do fragmento no ano de 1962.

Já para o ano de 1972, ou seja, dez anos após a primeira avaliação, é possível distinguir o avanço dos plantios de eucalipto na porção nordeste do fragmento (Figura 
5), reduzindo ainda mais a ligação com a Serra do Mar e também a abertura de novas áreas de plantio na porção oeste (Figura 6). A partir desta época, duas grandes áreas de mata, que antes compunham o fragmento, ficaram isoladas.

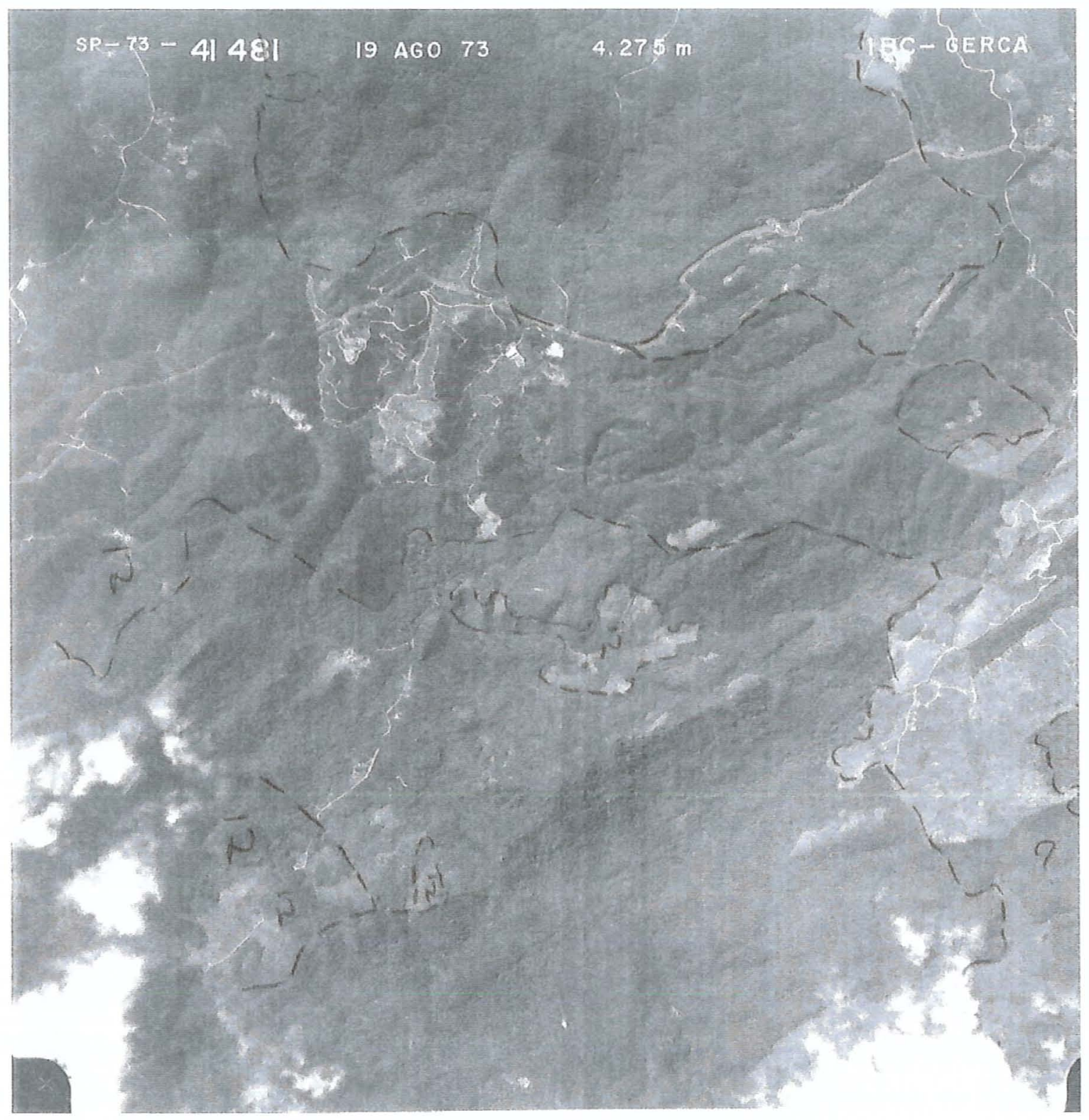

Figura 5 - Foto de 1972, enquadrando a porção inferior do fragmento. 


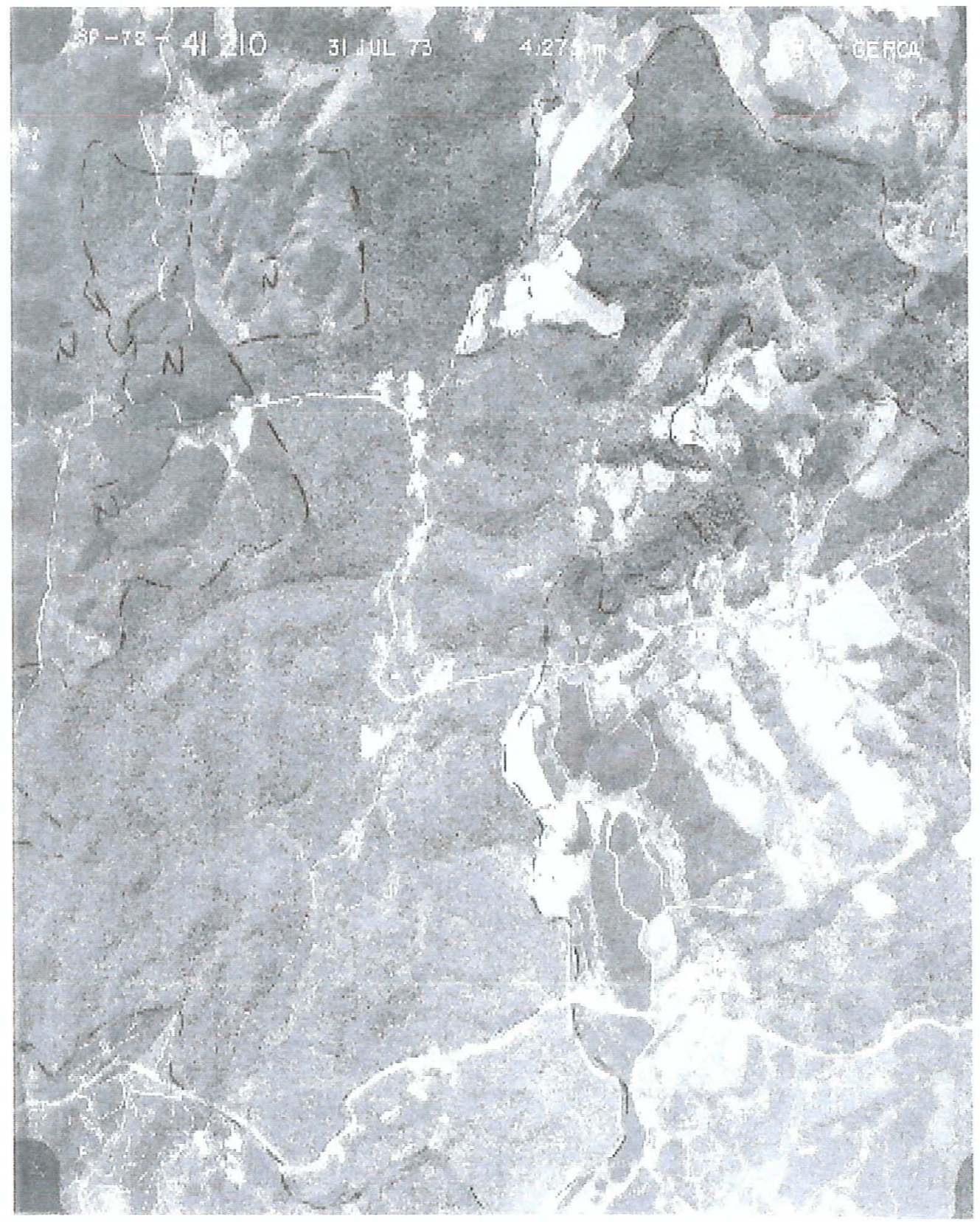

Figura 6 - Foto do ano de 1972 enquadrando o fragmento inteiro.

Nas fotos aéreas de 89 (Figura 7), é possível observar que o fragmento não sofreu fortes alterações em termos de diminuição de área, comparando-se com o ano de 72. Atualmente possui cerca de 700 ha em sua porção inferior delimitada pela estrada municipal. Além disto, neste ano já aparece a abertura para a passagem do linhão de força, cortando o fragmento no sentido leste-oeste. Esta linha de força foi instalada entre 
os anos de 75 e 76, para abastecer de energia o município de São Sebastião. Já o duto de água que liga o Reservatório Ponte Nova aos municípios da região de São Sebastião, teve inicio a instalação em 1926, segundo informações obtidas junto à SABESP.

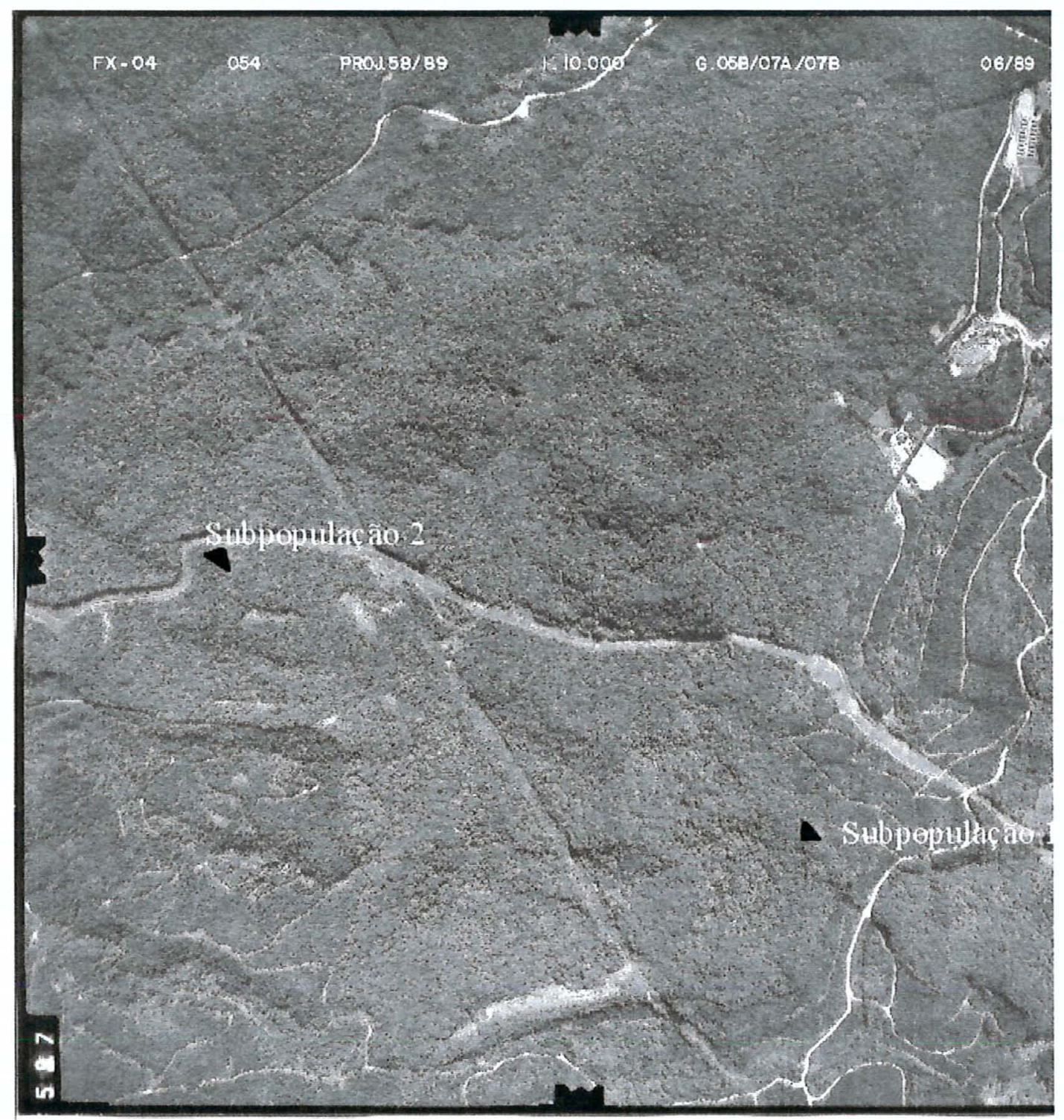

Figura 7- Foto do ano de 1989, enquadrando a porção inferior do fragmento com delimitação das áreas de amostragem.

Além da ocupação das áreas de entorno do fragmento, nota-se que desde 1962 existiam várias estradas que cortavam o fragmento, o que o tornou mais susceptível à exploração madeireira. Em entrevistas com os funcionários mais antigos e com a 
administração da Fazenda Itapanhaú, além de moradores do município que freqüentemente caçavam na área, confirmou-se algumas observações obtidas nas fotos: as terras pertencentes aos herdeiros do Sr. Vicente de Luca eram anteriormente da Empresa de Energia Elétrica do Estado de São Paulo, a antiga LIGHT. De acordo com os moradores mais antigos desta região, as terras eram cobertas por floresta (no dizer deles "mato") e a madeira retirada era utilizada para a produção de carvão, que abastecia a siderurgia do Município de Mogi das Cruzes. Também realizavam exploração seletiva de madeiras nobres na década de 60 , como jacarandá, cedro, copaíba, peroba, ipê, entre outras. Segundo relato de um antigo funcionário da Fazenda, a produção de carvão era realizada dentro da floresta, com a construção de fornos dentro de barranco, conforme mostra a Figura 8.

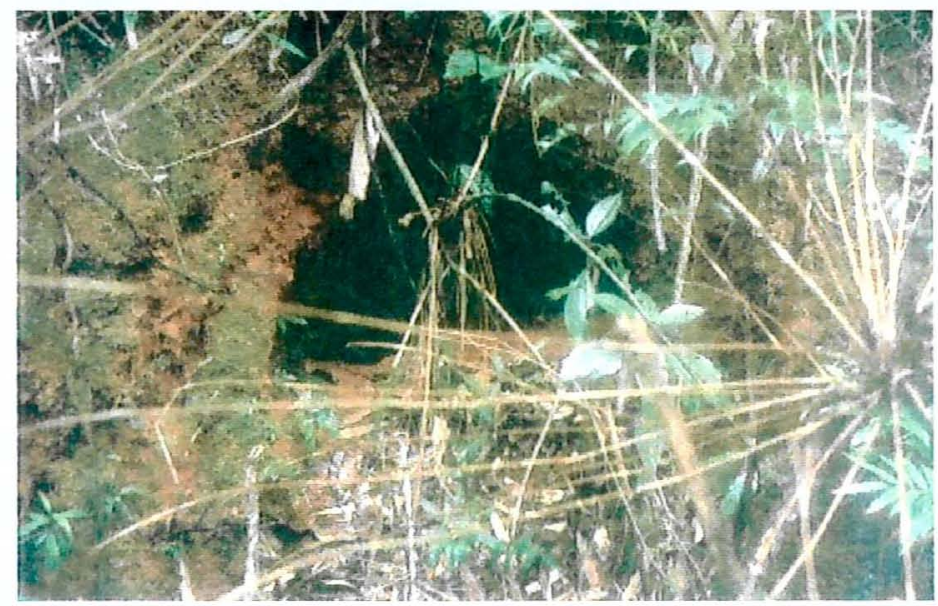

Figura 8 - Resquícios de um forno construído na mata para queima do carvão.

Avaliando o processo ao longo do tempo, nota-se claramente que o fragmento perdeu área principalmente nas décadas de 60 e 70 e que as perturbações sofridas pelo fragmento e no entorno, no decorrer dos últimos 40 anos, parecem ter influenciado o tipo de colonização e a recuperação das áreas remanescentes, que hoje ainda sofre pressão antrópica. A extração seletiva de madeira, a produção de carvão e a abertura das estradas no interior do fragmento provavelmente propiciaram a abertura de grandes clareiras que foram ocupadas pelo jacatirão, tendo-se estabelecido ao longo do tempo. 
Não existem sinais de queimadas recentes, o que também contribuiu para a recuperação destas áreas, apesar de estarem localizadas nas bordas.

Segundo Viana (1995), a borda do fragmento florestal é a área por onde a maior parte dos processos ligados à fragmentação geralmente se inicia, como mudanças na luminosidade, temperatura, umidade e velocidade do vento. Ainda segundo o autor, com o aumento da luminosidade na borda, ocorre um aumento no crescimento de espécies pioneiras. Isto pode explicar a colonização das áreas amostradas pelo jacatirão, que formou maciços com alta densidade de indivíduos.

Atualmente, as estradas que cortam o fragmento dão acesso à exploração clandestina do palmito, restando apenas indivíduos jovens. Além disto, através de observações realizadas na floresta, diagnosticou-se que a área continua sendo invadida por caçadores que realizam ceva ( presença de bacia com sal) e constróem girais para a captura de grandes mamíferos, como anta e capivara, e mesmo os pássaros que se alimentam dos frutos maduros do jacatirão são alvo de caça no fragmento.

\subsection{Descontinuidade das subpopulações de $M$. cinnamomifolia.}

A duas subpopulações de $M$. cinnamomifolia amostradas neste trabalho estão nas respectivas localizações: subpopulação 1: $45^{\circ} 58^{\prime} 52,4^{\prime \prime} \mathrm{W}, 23^{\circ} 38^{\prime} 19,8^{\prime \prime} \mathrm{S}$ e altitude: $931 \mathrm{~m}$ e; subpopulação $2: 45^{\circ} 59^{\prime} 44,8^{\prime \prime} \mathrm{W}, 23^{\circ} 38^{\prime} 25$,2'S e altitude: $838 \mathrm{~m}$. Através do programa Microstation, foi constatado que a distância entre as subpopulações é de cerca de $1493 \mathrm{~m}$.

Posteriormente à amostragem, realizou-se a abertura de um transecto entre as duas subpopulações para verificação da descontinuidade das formações. Pôde-se constatar uma ausência de regeneração da espécie, sendo detectado apenas 1 indivíduo juvenil, com cerca de $2,5 \mathrm{~m}$ de altura entre as formações. Outros indivíduos pré reprodutivos foram observados somente na beira da estrada que dá acesso ao fragmento, porém não no interior do fragmento. Estes dados indicam que o jacatirão, por apresentar sementes fotoblásticas positivas como foi comprovado por Queiroz (1982), necessita de grandes aberturas de luminosidade para que as sementes germinem e ocupem a área. 
Entretanto, a ausência de regeneração entre as duas subpopulações e mesmo dentro das áreas amostradas não significa necessariamente que as populações correm risco de desaparecimento, pois o banco de sementes no solo pode garantir a recolonização da área a partir da abertura de uma clareira grande. Além disto, a dispersão das sementes por pássaros influência na abrangência geográfica que a espécie pode alcançar, uma vez que este dispersor é de vôo longo, permitindo que sementes de jacatirão desta população colonizem áreas distantes.

Um outro fator que deve influenciar na ausência de regeneração entre as subpopulações é a existência de uma área de várzea, provavelmente limitando o estabelecimento do jacatirão entre as formações. Este gradiente ambiental determina o surgimento de espécies bastante características como Talauma ovata, entre outras, como é possível observar na Tabela 3.

Tabela 3. Espécies arbóreas identificadas no transecto entre as áreas de amostragem.

\begin{tabular}{|c|c|c|}
\hline Família & Nome científico & Nome comum \\
\hline Apocynaceae & Aspidosperma parvifolium A. DC. & Guatambu * \\
\hline Apocynaceae & Aspidosperma polyneuron M. Arg. & Peroba \\
\hline Arecaceae & Euterpe edulis Mart. & Palmito $A$ \\
\hline Bignoniaceae & Jacaranda puberula (Cham.) & Carobinha * \\
\hline Bombacaceae & Eriotheca candolleana (K. Schum.)A. Rab & Embiruçu * \\
\hline Cecropiaceae & Cecropia glasiou & Embaúba* \\
\hline Euphorbiaceae & Pera glabrata (Schott) Baill. & Sapateiro * \\
\hline Euphorbiaceae & Alchornea triplinervea(Spreng.)M. Arg. & Tapiá * \\
\hline Leguminosae & Inga sp. & Ingá + \\
\hline Magnoliaceae & Talauma ovata St. Hil. & Pinha do Brejo * \\
\hline Nyctaginaceae & Guapira oposita (Vell.) Reitz. & Guapira oposita \\
\hline Melastomataceae & Miconia cabucu Hoehne & Miconia cabuçu^ \\
\hline Melastomataceae & Miconia cinnamomifolia DC Naudin & Jacatirão* \\
\hline Meliaceae & Cabralea canjerana (Vell.) Mart. & Canjerana* \\
\hline Meliaceae & Cedrela fissilis (Vell.) & Cedro \\
\hline Myrtaceae & Psidium cattleianum (Sabine) & Araça vermelho * \\
\hline Myrtaceae & Campomanesia phaea (Berg.)Landr. & Cambuci * \\
\hline Myrtaceae & Eugenia uniflora $\mathrm{L}$. & Pitanga $A$ \\
\hline Proteaceae & Roupalia brasiliensis Klotz. & Carne de vaca * \\
\hline Rubiaceae & Psychotria nuda (Mart.) Wawra & Psychotria nuda $A$ \\
\hline Rutaceae & Esenbeckia leiocarpa Engl. & Guarantã * \\
\hline
\end{tabular}


Os símbolos ao lado do nome científico indicam a que estrato a espécie pertence:- dossel, subbosque, emergentes.

Deve-se deixar bem claro que este isolamento é apenas espacial e não deve ser entendido como uma barreira para o fluxo de pólen e sementes entre as duas populações, como foi determinado pelo estudo de distância genética neste trabalho.

\subsection{Desenvolvimento do protocolo e interpretação genética}

As interpretações dos padrões isoenzimáticos foram baseadas na análise de 8 indivíduos adultos coletados durante o período de amostragem. Dentre os 31 sistemas de revelação testados e relacionados na Tabela 1, foram selecionadas 12 enzimas que apresentaram maior atividade, porém algumas com baixa resolução, num processo de atribuir notas para os géis, que foram plastificados para eventual averiguação. Posteriormente, foi descartada a enzima PGM, com baixa resolução para os tampões de cuba e gel Histidina e Citrato Morfina (CM), selecionando-se 11 enzimas para teste nos sistemas de tampão gel/eletrodo descritos na Tabela 4.

Tabela 4. Sistemas de tampão gel eletrodo e sistemas enzimáticos utilizados.

\begin{tabular}{|c|c|c|c|c|}
\hline Enzima & Sistema t. gel/eletrodo & Concentração & Amperagem & Voltagem \\
\hline G6PDH & Borato de Lítio/Tris & Eletrodo: hidróxido de & $i_{\text {inicial }}=45 \mathrm{~mA}$ & $V_{\text {micial }}=148 \mathrm{~V}$ \\
\hline LAP & Citrato (19) & lítio $0,05 \mathrm{M}$, ácido bórico & constante & $\mathrm{V}_{30 \mathrm{~min}}=182 \mathrm{~V}$ \\
\hline 6PGDH & & $0,12 \mathrm{M} \mathrm{pH}: 8,6$ & & \\
\hline MR & & Gel: Tris $0,065 \mathrm{M}$, ácido & & \\
\hline GDH & & cítrico $\quad(0,01 \mathrm{M}) \quad \mathrm{pH} 8,1$ & & \\
\hline ACP & & (Scandalios, 1969) & & \\
\hline IDH & Tris Citrato (TC) & Eletrodo: Tris $0,223 \mathrm{M}$ & $\mathrm{i}_{\text {inicial }} 30 \mathrm{~A}$ & $V_{\text {inicial }}=150 \mathrm{~V}$ \\
\hline$\alpha-\mathbf{E S T}$ & & Ácido cítrico $0,086 \mathrm{M} \mathrm{pH}$ & $i_{30 \min }=35 \mathrm{~A}$ & $\mathrm{~V}_{30 \mathrm{~min}}=200 \mathrm{~V}$ \\
\hline PGI & & 7,5 & & \\
\hline DIA & & Gel: tampão do eletrodo & & \\
\hline \multirow[t]{2}{*}{ SKDH } & & diluído a $3,5 \%$ (Soltis et. & & \\
\hline & & al.1983) & & \\
\hline
\end{tabular}


Para revelação das isoenzimas escolhidas foram utilizados os protocolos de coloração apresentados no Anexo 1.

Dos 11 sistemas enzimáticos escolhidos, quatro (6PGDH, G6PDH, ACP e IDH) apresentaram locos monomórficos bastante nítidos e um sistema (MR) apresentou uma zona de atividade muito borrada, não sendo possível distinguir os alelos, como é possível observar na Figura 9. Seis sistemas apresentaram entre 1 e 2 locos polimórficos, totalizando 7 locos polimórficos.

A GDH apresentou uma região de atividade bastante expressiva, podendo ser distinguido um loco polimórfico, com três alelos. A PGI apresentou um loco polimórfico com dois alelos, em estrutura monomérica. A LAP apresentou apenas uma zona de atividade considerada um loco polimórfico com dois alelos, e polimorfismo correspondente à enzima monomérica. A SKDH também apresentou uma região interpretada como um loco polimórfico, e enzima de estrutura monomérica. Para a DIA, foi possível identificar duas regiões de atividade enzimática, sendo possível distinguir os alelos na região anódica. A $\alpha$-EST apresentou três regiões de atividade isoenzimática, sendo uma mais nítida interpretada como um loco monomórfico e duas regiões de migração mais lenta interpretadas como dois locos polimórficos, ambos correspondentes à enzimas de estrutura monomérica. Na Figura 10, estão apresentados os géis após a revelação de cada enzima com a intrerpretação genética dada (zimograma).

No presente trabalho, alguns dos problemas mais comuns relacionados à eletroforese de isoenzimas citados por Alfenas (1991) foram encontrados, como o aparecimento de bandas muito claras e de difícil deteç̧ão, não deteç̧ão de bandas, arraste de bandas a partir da origem e bandas com resolução e separação pobres. Segundo o autor, as principais causas estão relacionadas ao excesso de diluição durante o processo de extração, utilização de eletrodos impróprios, erro na mistura de soluções, presença de material fúngico ou vegetal insolúvel nas tiras de papel ou fornecimento contínuo de proteínas a partir do corte do gel. 
G6PDH

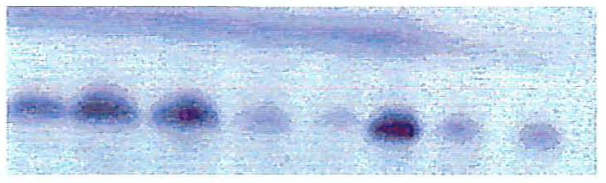

MR

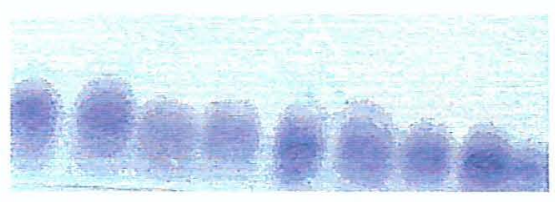

ACP

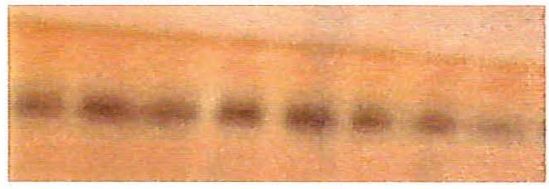

LAP

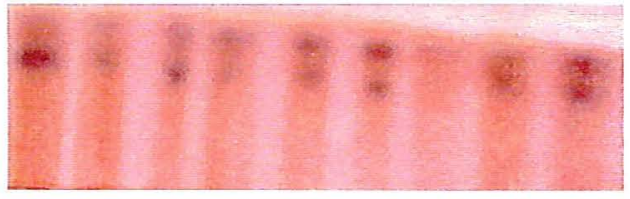

$\alpha$-EST

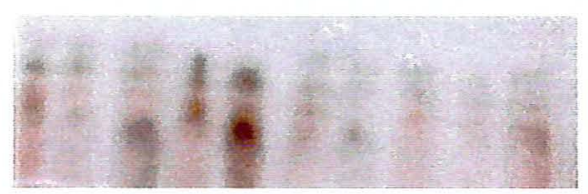

DIA

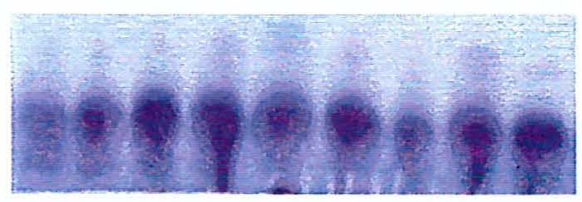

6PGDH

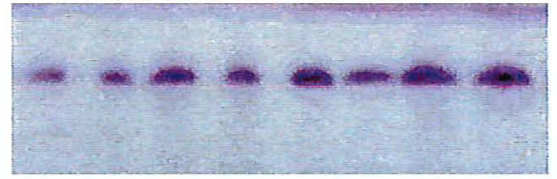

IDH

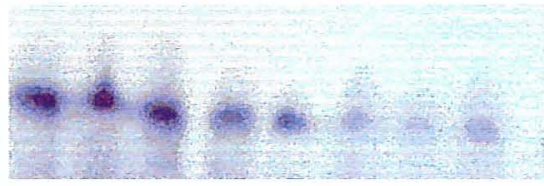

\section{GDH}

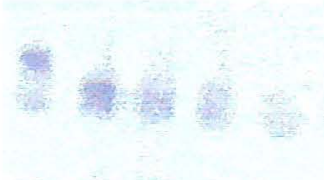

PGI

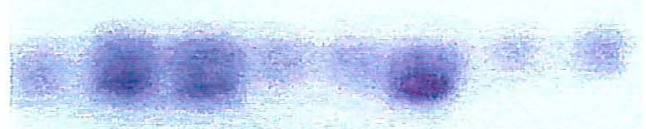

SKDH

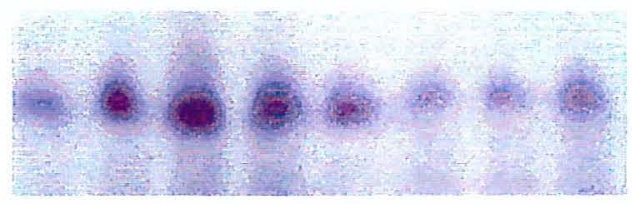

Figura 9 - Géis obtidos após a coloração de acordo com os diferentes protocolos obtidos para M. cinnamomifolia. 


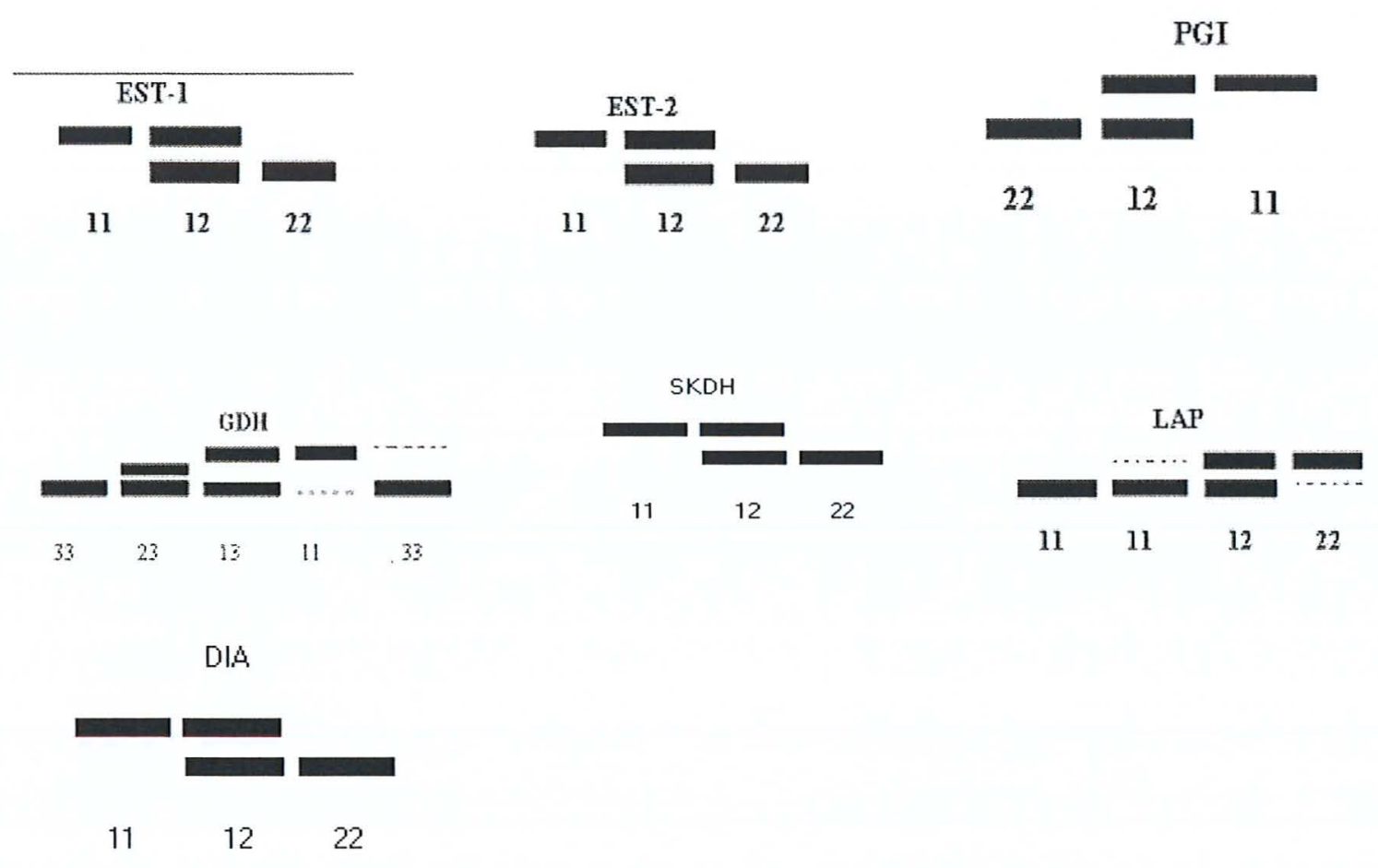

Figura 10 - Zimogramas representativos das interpretações dadas as bandas para $M$. cinnamomifolia.

\subsection{Variabilidade genética nas subpopulações}

\subsubsection{Riqueza e freqüências alélicas}

Foram genotipados 95 indivíduos adultos de Miconia cinammomifolia (DC.) Naudin, divididos a priori em duas subpopulações. No total foram encontrados 21 alelos, distribuídos em 10 locos isoenzimáticos, sendo este parâmetro quantificador da riqueza alélica da população. Perecin (2000) encontrou 31 alelos para as populações de Maytenus aquifolia e Sebbenn (1997) encontrou 13 alelos para uma população de Genipa americana.

Para a determinação das freqüências alélicas foram excluídos os locos 6PGDH, IDH, ACP e G6PDH que apresentaram uma completa fixação do alelo 1. As freqüências alélicas das duas subpopulações de indivíduos adultos de M. cinnamomifolia foram obtidas apenas para os locos considerados polimórficos utilizando o critério de 
frequência máxima de $95 \%$ do alelo mais freqüente. Esses resultados estão descritos na Tabela 5 .

Tabela 5. Distribuição das freqüências alélicas e número de alelos nas duas subpopulações de $M$. cinnamomifolia .

\begin{tabular}{|c|c|c|c|}
\hline Loco & Alelo & Subpop 1 & Subpop 2 \\
\hline \multirow[t]{4}{*}{ GDH-1 } & 1 & 0,117 & 0,065 \\
\hline & 2 & 0,032 & 0,065 \\
\hline & 3 & 0,851 & 0,870 \\
\hline & $\mathrm{n}$ & 47 & 46 \\
\hline \multirow[t]{3}{*}{ PGI-1 } & 1 & 0,522 & 0,478 \\
\hline & 2 & 0,478 & 0,522 \\
\hline & $n$ & 45 & 45 \\
\hline \multirow[t]{3}{*}{ LAP-1 } & 1 & 0,445 & 0,486 \\
\hline & 2 & 0,545 & 0,514 \\
\hline & $\mathrm{n}$ & 33 & 35 \\
\hline \multirow[t]{3}{*}{ SKDH-1 } & 1 & 0,948 & 0,968 \\
\hline & 2 & 0,052 & 0,032 \\
\hline & $n$ & 48 & 47 \\
\hline \multirow[t]{3}{*}{ DIA-1 } & 1 & 0,756 & 0,798 \\
\hline & 2 & 0,244 & 0,202 \\
\hline & $\mathrm{n}$ & 45 & 47 \\
\hline \multirow[t]{4}{*}{ EST-1 } & 1 & 0,552 & 0,550 \\
\hline & 2 & 0,448 & 0,438 \\
\hline & 3 & 0 & 0,013 \\
\hline & $\mathrm{n}$ & 48 & 40 \\
\hline \multirow[t]{4}{*}{ EST-2 } & 1 & 0,667 & 0,629 \\
\hline & 2 & 0,333 & 0,357 \\
\hline & 3 & 0 & 0,014 \\
\hline & $\mathrm{n}$ & 39 & 35 \\
\hline Total de alelos & 17 & 15 & 17 \\
\hline
\end{tabular}


Pode-se perceber que o alelo 3 da GDH apresentou alta freqüência sobre os alelos 1 e 2. A SKDH também apresentou esta discrepância entre as frequêencias dos alelos 1 e 2 . Os locos PGI, LAP tiveram as freqüências distribuídas equalitariamente entre os alelos e a DIA encontra-se em uma posição intermediária.

De acordo com Yeh (2000) os fatores que afetam as freqüências alélicas em uma população de cruzamento aleatório são deriva genética, mutação, seleção natural e migração. Frankel et al. (1995), sugerem que a maior equidade nas freqüências alélicas numa população seria um indicador de maior diversidade genética. Ainda segundo os autores, estas populações estariam mais protegidas dos efeitos de deriva do que as que tem alelos muito menos freqüentes do que outros.

A distribuição das freqüências alélicas entre as subpopulações foi bastante semelhante para os 5 primeiros locos. Já para a EST -1 e EST-2, o alelo 3 aparece em baixa frequência $(0,013$ e 0,014, respectivamente),exclusivamente na subpopulação 2 .

Estes alelos raros foram classificados por Muller-Starck \& Schubert (2000) como pré-adaptativos, pois segundo Bergmann et al. (1990) a ocorrência destes genes é interpretada como um tampão para facilitar a adaptação futura sob alguma condição de stress. Futuyma (1992) sugere que existe a tendência de que desapareçam, a menos que a seleção natural os favoreça. Já Maruyama \& Fuerst (1985) argumentam que um efeito de fundador pode aumentar a freqüência destes alelos na população.

De maneira geral, a distribuição das freqüências alélicas para todos os locos foi muito semelhante para as duas subpopulações, sugerindo que pode não haver divergências entre as mesmas e ambas compartilham o mesmo conjunto gênico.

\subsection{2 Índices de diversidade intrapopulacional}

Os índices de diversidade estimados foram o número médio de alelos por loco $(\hat{A})$, a porcentagem de locos polimórficos $(\hat{P})$ ao critério de $95 \%$ de probabilidade, a heterozigosidade observada $\left(\hat{H}_{o}\right)$ e a heterozigosidade esperada $\left(\hat{H}_{e}\right)$ segundo 
expectativas do equilíbrio de Hardy-Weinberg para os tamanhos da amostra (n) por loco, descritos na Tabela 6.

Tabela 6. Índices de diversidade intrapopulacionais em árvores adultas de subpopulações de $M$. cinnamomifolia .

\begin{tabular}{cccc}
\hline Índices & Subpopulação 1 & Subpopulação 2 & Média \\
\hline $\mathbf{n}$ & $44(2,1)$ & $43(2,1)$ & 43 \\
$\hat{A}$ & $2,1(0,14)$ & $2,4(0,2)$ & 2,3 \\
$\hat{P}(\mathbf{0 , 9 5 )}$ & 1,000 & 0,857 & 0,928 \\
$\hat{H}_{o}$ & $0,399(0,079)$ & $0,412(0,082)$ & 0,406 \\
$\hat{H}_{e}$ & $0,385(0,058)$ & $0,376(0,066)$ & 0,381 \\
$\hat{f}$ & $-0,038$ & $-0,097$ & $-0,067$ \\
\hline
\end{tabular}

n: número de indivíduos; $\hat{A}$ : número de alelos por loco; $\hat{P}$ : Porcentagem de locos polimórficos; $\hat{H}_{n}$ : heterozigosidade observada; $\hat{H}_{e}$ : heterozigosidade esperada e $\hat{f}$ : índice de fixação.

Em relação ao número médio de alelos por loco $(\hat{A})$, pode-se concluir que este índice foi alto e não diferiu significativamente para as duas subpopulações $(2,14 \pm 0,14 \mathrm{e}$ $2,43 \pm 0,20$, respectivamente). Neste sentido, é necessário citar que $M$. cinnamomifolia é uma espécie de polinização zoocórica. Daí o fato de apresentar índices próximos aos dos organizados por Hamrick \& Godt (1990), revelando que espécies de polinização cruzada apresentam os maiores índices de riqueza alélica $(\hat{A}=2,4)$, seguidas pelas espécies polinizadas pelo vento $(\hat{A}=2,29)$ e que espécies de distribuição ampla e modo de dispersão de sementes exozoocóricos apresentaram $\hat{A}=2,96$.

Além da espécie ser presumivelmente de cruzamento, apresenta ampla distribuição geográfica sendo encontrada desde os Estados da Bahia até Santa Catarina e em relação à dispersão das sementes, seus frutos são importante fonte de alimento para pássaros, segundo descreve Pereira (1998), o que the confere a possibilidade de se estabelecer tanto em sítios próximos como em sítios distantes.

Considerando apenas os locos polimórficos utilizados nas análises, o índice $\hat{P}$ a $95 \%$ de probabilidade, é igual a 1 para a subpopulação 1 e $0,85(85 \%)$ para a 
subpopulação 2. Este valor cai um pouco quando se considera todos os locos testados (incluindo os monomórficos) para as duas subpopulações, atingindo o valor de 0,7 (70\%). Comparando este índice com a estimativa de 50\% de polimorfismo para espécies vegetais, encontradas por Hamrick \& Godt (1990), pode-se concluir que a espécie apresenta um alto polimorfismo.

A heterozigosidade observada $\left(\hat{H}_{o}\right)$ também foi considerada alta para as subpopulações $(0,39$ e 0,41 , respectivamente) quando comparada com outras espécies arbóreas tropicais citadas na Tabela 7. A espécie que mais se aproximou desse índice foi Bauhinia forficata $(0,45)$, que também é uma espécie pioneira antrópica (Santos, 1994), segundo conceito descrito por Kageyama (1993). Lepsh-Cunha também encontrou altos indices de diversidade para Couratari multiflora $\left(\hat{H}_{o}=0,359\right.$ e $\left.\hat{H}_{e}=0,431\right)$ e Couratari guianensis $\left(\hat{H}_{o}=0,203\right.$ e $\left.\hat{H}_{e}=0,420\right)$.

Tabela 7. Estudos genéticos com algumas espécies arbóreas da Mata Atlântica - Brasil.

\begin{tabular}{lllcccc}
\hline \multicolumn{1}{c}{ Espécie } & \multicolumn{1}{c}{ Familia } & D & $\hat{P}$ & $\hat{A}$ & $\hat{H}_{o}$ & $\hat{H}_{e}$ \\
\hline Aspidosperma polyneuron (1) & Apocynaceae & $\mathrm{I}$ & 50,0 & 8 & 0,236 & 0,243 \\
Bauhinia forficata (2) & Caesalpinaceae & $\mathrm{I}$ & 100,0 & 4 & 0,451 & 0,503 \\
Bowdichia virgilioides (3) & Fabaceae & $\mathrm{R}$ & 28,0 & 10 & 0,126 & 0,126 \\
Cariniana legalis (4) & Lecythidaceae & $\mathrm{I}$ & 30,0 & 10 & 0,140 & 0,140 \\
Chorisia speciosa (5) & Bombacaceae & $\mathrm{R}$ & 77,8 & 9 & 0,245 & 0,284 \\
Cordia trichotoma (6) & Boraginaceae & $\mathrm{R}$ & 40,0 & 10 & 0,184 & 0,184 \\
Cryptocarya moscata (7) & Lauraceae & $\mathrm{I}$ & 85,0 & 20 & 0,323 & 0,351 \\
Genipa americana (8) & Rubiaceae & $\mathrm{C}$ & 50,0 & 8 & 0,195 & 0,182 \\
Johanesia princeps (9) & Euphorbiaceae & $\mathrm{I}$ & 27,0 & 10 & 0,141 & 0,141 \\
Myracroduon urundeuva (10) & Anarcadiaceae & $\mathrm{R}$ & 66,7 & 3 & 0,150 & 0,358 \\
Cedrela fissilis (11) & Meliaceae & $\mathrm{R}$ & 76,9 & 14 & 0,222 & 0,243 \\
Euterpe edulis (12) & Arecaceae & $\mathrm{C}$ & 100,0 & 7 & 0,496 & 0,463 \\
\hline
\end{tabular}

$\mathrm{I}=$ intermediária $\mathrm{R}=$ Rara e $\mathrm{C}=\mathrm{Comum} ; \mathrm{D}:$ Densidade espacial; $\hat{A}=\mathrm{n}^{\circ}$. de alelos por loco; $\hat{P}=$ polimorfismo $(\%) ; \hat{H}_{e}=$ diversidade gênica e $\hat{H}_{o}=$ heterozigosidade observada 
Autores: 1 Maltez (1997); 2 Santos (1994); 3 Herrit (1991); 4 Herrit (1991); 5 Souza (1997); 6 Herrit (1991); 7 M oraes (1998); 8 Sebbenn (1997); 9 Herritt (1991); 10 Moraes (1993); 11 Gandara (1996); 12Reis(1996)

Fonte: Kageyama (2001)

A alta diversidade gênica encontrada para $M$. cinnamomifolia pode confirmar a hipótese de que populações de espécies colonizadoras em áreas antropizadas conseguem manter altos índices de diversidade, isso por virem de diferentes populações ou populações base com alta diversidade. Huenneke (1991) cita, entre várias contribuições

que a variação genética tem para a viabilidade das populações, o fato de que a variação genética de populações fundadoras influenciam no sucesso dos grupos de espécies colonizadoras.

A $\hat{H}_{o}$ foi maior do que $\hat{H}_{e}$ para as duas subpopulações, evidenciando que existe um excesso de heterozigotos, em relação ao EHW, reflexo do baixo índice de fixação (0,067). Este índice mede a redução da heterozigosidade em relação ao esperado para uma população panmítica, ou seja, quando os valores de $f$ são iguais a zero, a população está adequada as proporções do Equilíbrio de Hardy-Weinberg. Quando os valores são significativamente maiores ou menores que zero, indica que há um excesso de homozigotos ou de heterozigotos, respectivamente.

Sebbenn et al. (1998) também encontrou um índice de fixação negativo para indivíduos adultos de G. americana ressaltando porém que o quadro se inverte na maioria dos casos para indivíduos jovens (plântulas), sugerindo seleção contra homozigotos.

Como para as populações este índice de fixação não foi significativamente diferente de zero, podemos concluir que as populações de M. cinnamomifolia encontram-se nas proporções do EHW.

\subsubsection{Estrutura Genética das Subpopulações}


Foram estimados o índice de fixação total da população $(\hat{F})$, índice de fixação médio dentro das subpopulações $(\hat{f})$ e o coeficiente de coancestralidade $\left(\hat{\theta}_{p}\right)$, a partir das freqüências alélicas. As estimativas de $\hat{f}, \hat{F}$ e $\hat{\theta}_{p}$ correspondem as estimativas $F_{i s}$, $F_{i t} F_{s t}$ de Wright (1965) e ao $G_{s t}$ de Nei (1973).

Tabela 8. Índices de Fixação e Coefĩciente de Coancestralidade entre duas subpopulações de Miconia cinnamomifolia.

\begin{tabular}{cccc}
\hline Loco & $\hat{f}$ & $\hat{F}$ & $\hat{\theta}_{p}$ \\
\hline GDH-1 & 0,058 & 0,055 & $-0,003$ \\
PGI-1 & $-0,102$ & $-0,109$ & $-0,006$ \\
LAP-1 & $-0,227$ & $-0,238$ & $-0,010$ \\
SKDH-1 & 0,485 & 0,479 & $-0,011$ \\
DIA-1 & $-0,027$ & $-0,033$ & $-0,005$ \\
EST-1 & $-0,149$ & $-0,160$ & $-0,010$ \\
EST-2 & 0,015 & 0,003 & $-0,012$ \\
Média & $\mathbf{- 0 , 0 7 1}(-0,14$ a 0,03$)$ & $\mathbf{- 0 , 0 8 0}(-0,15$ a 0,03$)$ & $\mathbf{- 0 , 0 0 8}(-0,01$ a $-0,006)$ \\
\hline
\end{tabular}

Limite I. C. $95 \%$

Pode-se observar na Tabela 8 o valor negativo de $\hat{\theta}_{p}$, indicando a presença de fortes correlações intraclasses e que os genótipos de diferentes subpopulações são mais semelhantes entre si do que genótipos da mesma subpopulação. Este resultado, por sua vez, indica que o fluxo gênico entre as subpopulações é alto.

Levando-se em conta que as duas subpopulações estão distantes cerca de $1,5 \mathrm{~km}$, era esperado que houvesse uma baixa divergência entre elas, principalmente por ser uma espécie polinizada por insetos e dispersa por pássaros, criando-se uma tendência para ocorrência de altas taxas de fluxo gênico. Esta divergência poderia ocorrer se as duas subpopulações fossem originadas a partir de diferentes populações base na época da colonização ou se estivessem isoladas e sofrendo diferentes pressões de forças evolutivas (seleção e deriva).

Em relação às estimativas de $\hat{f}$ e $\hat{F}$, os locos GDH $(0,058$ e 0,055$)$ e EST-2, $(0,015$ e 0,003$)$ apresentaram um excesso de homozigotos, porém com valores muito 
próximos de zero para as duas subpopulações. Somente o loco SKDH apresentou valores positivos e altos $(0,485$ e 0,479$)$. Os locos que apresentaram valores negativos, indicam excesso de heterozigotos, como o loco DIA $(-0,027$ e $-0,033)$ apresentou os valores mais próximos de zero e os locos que apresentaram altos valores para as estimativas de $\hat{f} \mathrm{e}$ $\hat{F}$ estão PGI $(-0,102$ e $-0,109)$ e LAP $(-0,227$ e $-0,238)$.

Resumindo, os valores médios de $\hat{f}$ e $\hat{F}$ similares, negativos e não significativos, confirmando o resultado de $\hat{\theta}_{p}$. A ausência de endogamia na média das subpopulações sugere que a espécie é de cruzamento e a ausência de endogamia para o conjunto de subpopulações sugere que não existe divergência genética. $O$ tamanho relativamente grande da população $(n=100)$ previne os efeitos de deriva genética.

\subsection{Sistema de Reprodução}

\subsubsection{Teste de Ajuste do Equilíbrio de Hardy-Weinberg}

O teste exato de Fischer não revelou desvios significativos para cinco dos sete locos analisados. Apenas dois locos (DIA e LAP) apresentaram desvios em relação as proporções do EHW, sendo este último observado apenas na subpopulação 1, como é possível observar na Tabela 9. Isto indica que, para a maioria dos locos, os cruzamentos ocorrem de forma aleatória nas populações.

Tabela 9. Teste exato de Fischer (P de Fischer) as Proporções do Equilíbrio de HardyWeinberg em árvores adultas de $M$. cinnamomifolia .

\begin{tabular}{ccc}
\hline Loco & P subpop 1 $_{\text {s }}$ & P $_{\text {subop 2 }}$ \\
\hline GHD-1 & 1,000 & 0,561 \\
PGI-1 & 1,000 & 0,240 \\
LAP-1 & $0,730^{*}$ & 0,046 \\
SKDH-1 & 0,020 & 1,000 \\
DIA-1 & $0,704^{*}$ & $0,661^{*}$ \\
EST - 1 & 0,047 & 1,000 \\
EST - 2 & 1,000 & 1,000 \\
\hline
\end{tabular}


* P significativo a $5 \%$.

É importante ressaltar que, embora os resultados tenham mostrado que os dados desta geração se adeqüem ao EHW, esta sendo analisada apenas uma geração, o que pode não garantir a aderência ao modelo. Segundo Vencovsky e Coelho (1999), uma geração pode ter suas proporções aderindo a Hardy-Weinberg por apomixia, entre outros fatores.

\subsubsection{Taxa de cruzamento aparente}

Para a obtenção da taxa de cruzamento aparente $\left(\hat{t}_{a}\right)$, utilizando-se o coeficiente de endogamia, é necessário verificar a existência do equilíbrio de endogamia de Wright para os locos que não estão em Equilíbrio de Hardy-Weinberg. Quando os valores não são significativos, aceita-se a suposição de equilíbrio sendo, segundo Vencovsky (1992), válido então se estimar a taxa de fertilização cruzada aparente.

No caso da Miconia cinnamomifolia, os locos que apresentaram desvios em relação as proporções esperadas tem apenas dois alelos, não sendo possível testar o equilíbrio de endogamia. Assim sendo, os locos LAP-1 e DIA-1 foram eliminados para o cálculo da taxa de cruzamento aparente.

Tabela 10. Taxa de Cruzamento Aparente $\left(\hat{t}_{a}\right)$ para as subpopulações de $M$. cinnamomifolia.

\begin{tabular}{cccc}
\hline Locos & Subpop 1. & Subpop 2. & População \\
\hline GDH-1 & 0,937 & 0,840 & 0,892 \\
PGI-1 & 1,026 & 1,474 & 1,237 \\
SKDH-1 & 0,116 & 1,045 & 0,350 \\
EST - 1 & 1,842 & 0,952 & 1,364 \\
EST - 2 & 1,052 & 0,893 & 0,982 \\
& & & \\
Média & $\mathbf{0 , 9 9 5}$ & $\mathbf{1 , 0 4 1}$ & $\mathbf{0 , 9 6 5}$ \\
\hline
\end{tabular}


As taxas de cruzamento aparente $\left(\hat{t}_{a}\right)$ para as subpopulações de $M$. cinnamomifolia foram de 0,995 e 1,041, respectivamente. Considerando-se que as duas subpopulações compartilham a mesmo conjunto gênico, estimou-se a $\hat{t}_{a}$ para a população, estando o índice em torno de 0,97 , o que sugere que a espécie é predominantemente de cruzamento. Isto deve-se aos índices negativos de endogamia intrapopulacional encontrados.

\subsection{Tamanho efetivo}

O tamanho efetivo populacional trata da representatividade genética das amostras, sendo de grande importância seu conhecimento nas atividades de coleta de sementes de plantas alógamas pois, segundo Vencovsky (1987), não adianta coletar milhares de sementes de uma única planta, que não eqüivalerão a quatro sementes colhidas de diferentes árvores.

Tabela 11. Tamanho amostral (n) e tamanho efetivo $\left(\hat{N}_{e}\right)$ para as subpopulações e população de M. cinnamomifolia.

\begin{tabular}{cccc}
\hline & Spop1 & Spop2 & População \\
\hline $\boldsymbol{n}$ & 43 & 42 & 95 \\
$\hat{N}_{e}$ & 50 & 47 & 103 \\
\hline
\end{tabular}

Os tamanhos efetivos para as subpopulações foram maiores que o tamanho amostral, conseqüência dos índices negativos de fixação, que por sua vez são decorrentes da alta heterozigosidade detectada. Isto significa que, geneticamente, as 95 árvores amostradas na população representam 103 indivíduos de uma população panmítica ideal.

Sebbenn (2001) cita que muitos autores têm encontrado que o tamanho efetivo costuma ser inferior ao tamanho físico. Segundo Vencovsky (1987) o tamanho efetivo depende principalmente dos níveis de endogamia e parentesco existentes na amostra, 
sendo que quanto maior estes níveis, menor será a representatividade da amostra.

A análise da diversidade genética revelou que a população tem potencial para conservação in situ, podendo ser calculada a área mínima viável tomando-se como base um $\hat{N}_{e}$ de 50, que segundo Frankel \& Soulé, 1981 já é suficiente para prevenir a perda de alelos raros em poucas gerações e de 500 garante a preservação de alelos raros a longo prazo. A relação $\hat{N}_{e} / \mathrm{n}$ da média da população é igual a 1,08 e a densidade média encontrada nas áreas de amostragem é de 50 indivíduos adultos por hectare. A partir destes dados a área mínima viável é de 0,92 ha $(50 /(50 \times 1,08)$. Já para a conservação a longo prazo, seria necessário uma área de 9,26 ha. Desta forma pode-se concluir que o fragmento possui, com 700 ha, uma ótima perspectiva para a conservação dessas populações.

\subsection{Estrutura genética espacial}

A análise de autocorrelação espacial é utilizada para investigar a estrutura genética espacial, verificando se os genótipos de uma população apresentam distribuição aleatória ou estruturada, ou seja, neste último caso se as árvores que estão mais próximas tendem a ser mais aparentadas entre si.

De acordo com Sebbenn (1997), o conhecimento do padrão de distribuição é importante para minimizar o impacto de práticas de manejo na sustentabilidade dos recursos genéticos, bem como para o estabelecimento de estratégias de amostragem de populações naturais tanto para a conservação quanto para fins de melhoramento, possibilitando a obtenção de amostras mais representativas.

As análises de autocorrelação foram feitas individualmente para as subpopulações utilizando a metodologia de classes de distância e o Índice de Moran, relacionados nas Tabelas 12 e 13 .

Tabela 12. Índice de Moran ( I ) para a subpopulação 1. 


\begin{tabular}{lccccccccccc}
\hline Loco & Alelo & 1 & 2 & 3 & 4 & 5 & 6 & 7 & 8 & 9 & 10 \\
\hline PGI & 1 & $-0,07$ & 0,06 & $0,16^{*}$ & 0,05 & $-0,07$ & $-0,02$ & 0,04 & $-0,21^{*}$ & $-0,12$ & $-0,03$ \\
LAP & 1 & 0,03 & 0,02 & 0,03 & $-0,03$ & $0,2^{* *}$ & $-0,02$ & $-0,13$ & 0 & $-0,36^{* *}$ & 0,03 \\
SKD & 1 & $0,28^{* *}$ & $0,17^{*}$ & $-0,2^{*}$ & $-0,16^{*}$ & $-0,15$ & $-0,15$ & 0,04 & 0,08 & $-0,03$ & $-0,1$ \\
DIA & 1 & $0,48^{* *}$ & $0,36^{* *}$ & $0,21^{* *}$ & $0,23^{* *}$ & $-0,03$ & $-0,14$ & $-0,21^{*}$ & $-0,7$ & $-0,36^{* *}$ & $-0,05$ \\
EST1 & 1 & $0,8^{* *}$ & $0,58^{* *}$ & $0,33^{* *}$ & $0,18^{* *}$ & $-0,25^{* *}$ & $-0,27^{* *}$ & $-0,47^{* *}$ & $-0,63^{* *}$ & $-0,34^{* *}$ & $-0,15^{*}$ \\
EST2 & 1 & 0,02 & $-0,05$ & 0,04 & $-0,18^{*}$ & $-0,19^{*}$ & 0,12 & 0,01 & 0,08 & $-0,06$ & 0 \\
GDH & 1 & $0,44^{* *}$ & $-0,01$ & 0,03 & 0,1 & $0,12^{*}$ & $-0,07$ & $-0,16^{*}$ & $-0,41^{* *}$ & $-0,21^{*}$ & $-0,04$ \\
GDH & 2 & $0,17^{* *}$ & 0,05 & $-0,07$ & $-0,06$ & $-0,02$ & $-0,12$ & $-0,04$ & $-0,06$ & $-0,04$ & $-0,03$ \\
GDH & 3 & $0,54^{* *}$ & $0,4^{* *}$ & $0,15^{*}$ & 0,06 & $-0,05$ & $-0,24^{* *}$ & $-0,29^{* *}$ & $-0,48^{* *}$ & $-0,24^{* *}$ & $-0,06$ \\
Média & & 0,3 & 0,18 & 0,08 & 0,02 & $-0,05$ & $-0,1$ & $-0,13$ & $-0,26^{* *}$ & $-0,19$ & $-0,05$ \\
\hline P<0,05; & $* * \mathrm{P}<0,01$. & & & & & & & & &
\end{tabular}

Classes de distância em metros: $1=0-25 ; 2=25-40 ; 3=40-54 ; 4=54-69 ; 5=69-80 ; 6=80$ $94 ; 7=94-107 ; 8=107-119 ; 9=119-153 ; 10=153-236$.

Tabela 13. Índice de Moran (I ) para a subpopulação 2.

\begin{tabular}{lccccccccccc}
\hline Loco & Alelo & 1 & 2 & 3 & 4 & 5 & 6 & 7 & 8 & 9 & 10 \\
\hline PGI & 1 & 0,05 & $-0,07$ & $-0,03$ & $-0,14$ & $-0,05$ & 0,07 & $-0,1$ & 0,07 & 0,03 & $-0,05$ \\
LAP & 1 & $-0,11$ & $-0,07$ & $-0,02$ & 0,04 & $-0,09$ & 0,07 & 0,04 & $-0,07$ & $-0,03$ & 0,01 \\
SKD & 1 & 0,07 & $-0,12$ & $-0,05$ & $-0,1$ & $-0,02$ & $0,18^{* *}$ & $-0,04$ & $-0,03$ & $-0,11$ & 0 \\
DIA & 1 & 0,05 & $-0,06$ & 0 & $-0,06$ & $-0,06$ & 0 & $-0,04$ & $-0,07$ & $-0,05$ & 0,07 \\
GDH & 1 & $-0,12$ & $0,17^{* *}$ & $0,13^{*}$ & $-0,13$ & $-0,12$ & $-0,09$ & $0,11^{*}$ & $-0,08$ & $-0,06$ & $-0,02$ \\
GDH & 2 & $0,2^{* *}$ & $0,21^{* *}$ & 0,01 & $-0,13$ & $-0,12$ & $-0,03$ & $-0,16^{*}$ & $-0,1$ & $-0,09$ & $-0,02$ \\
GDH & 3 & $0,19^{* *}$ & 0,11 & $0,31^{* *}$ & $-0,31^{* *}$ & $-0,15$ & 0,05 & 0,12 & $-0,23^{* *}$ & $-0,09$ & $-0,19^{*}$ \\
EST1 & 1 & $0,18^{*}$ & $-0,19^{*}$ & $-0,05$ & $-0,11$ & $-0,01$ & 0,02 & 0,05 & $-0,13$ & 0 & 0,04 \\
EST1 & 2 & $-0,02$ & $-0,23^{* *}$ & 0,01 & 0,06 & 0,04 & $-0,05$ & 0,04 & $-0,01$ & $-0,06$ & 0,01 \\
EST1 & 3 & $-0,03$ & 0,01 & 0,01 & $-0,03$ & $-0,05$ & $-0,01$ & $-0,03$ & 0 & $-0,08$ & $-0,02$ \\
EST2 & 1 & $0,24^{* *}$ & $-0,015$ & $-0,12$ & $-0,02$ & $-0,03$ & $0,13^{*}$ & $-0,13$ & $-0,08$ & $-0,1$ & 0,05 \\
EST2 & 2 & 0,03 & 0 & $-0,1$ & $-0,02$ & 0,02 & 0,08 & $-0,13$ & $-0,06$ & $-0,02$ & 0 \\
EST2 & 3 & $-0,04$ & $-0,01$ & 0 & $-0,04$ & 0 & $-0,05$ & $-0,02$ & $-0,02$ & $-0,03$ & $-0,03$ \\
& & & & & & & & & & & \\
Média & & 0,05 & $-0,03$ & 0,01 & $-0,08$ & $-0,05$ & 0,03 & $-0,02$ & $-0,06$ & $-0,05$ & $-0,01$ \\
\hline
\end{tabular}

$* \mathrm{P}<0,05 ; * * \mathrm{P}<0,01$.

Classes de distância em metros: $1=0-29 ; 2=29-44 ; 3=44-59 ; 4=59-70 ; 5=70-80 ; 6=80$ $92 ; 7=92-106 ; 8=106-122 ; 9=122-150 ; 10=150-212$.

Para a subpopulação 1, 40,3\% dos valores apresentaram algum grau de significância em relação ao valor zero. Já para a subpopulação 2 , apenas $13,1 \%$ dos valores apresentaram algum grau de significância.

Pode-se observar nas Tabelas 12 e 13 que todos os alelos oscilaram de valores positivos a negativos, contendo inclusive muitos valores significativamente diferentes de zero, principalmente para as classes de 1 a 3 na subpopulação 1 e para a classe 1 da 
subpopulação 2. Isto indica a existência de estruturação e que os indivíduos mais próximos são mais aparentados. Este padrão é mais facilmente observado nos correlogramas feitos para cada alelo (Anexo 2) e para as médias (Figuras 12).

\section{Média}

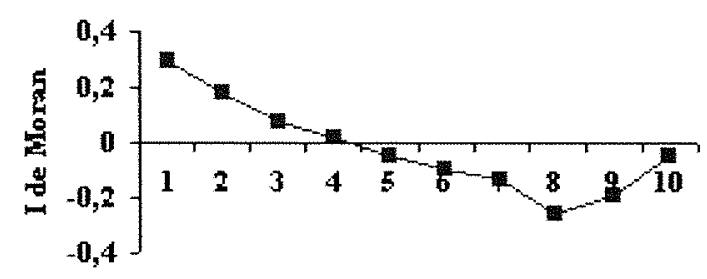

Classes de distância

Média

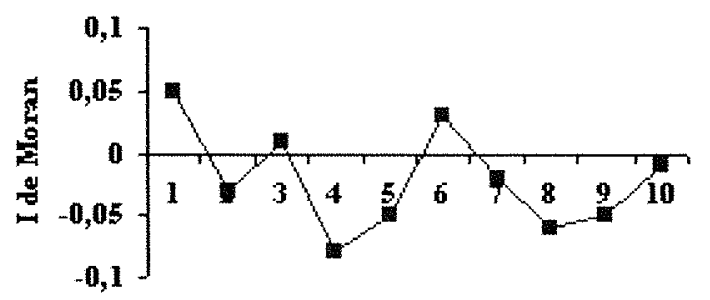

Classes de distância

Figura 11 - Correlogramas paras as médias dos locos das subpopulações 1 e 2.

Kageyama et al. (1998) encontraram também estruturação familiar $\left(I_{\text {Moran }}=0,4\right)$ em uma população de cedro (Cedrela fissilis) em floresta secundária, onde sua densidade chegava a cerca de 30 indivíduos por hectare, sendo que em uma floresta primária não passa de 1 indivíduo/ha. Segundo os autores, uma das principais implicações negativas disto é que deverá ocorrer o problema de endogamia nas futuras gerações, já que os indivíduos mais próximos tem um certo grau de parentesco, levando à problemas de má adaptação da população com perda de vigor e má reprodução em seus indivíduos. Lovelless \& Hamrick (1984) explicam que, como a gravidade deposita sementes próximas aos pais, isto aumenta a estrutura familiar, reduzindo o $\hat{N}_{e}$ e 
promovendo divergência dentro e entre populações. Já a dispersão mediada por animais é mais distante e variável que outros vetores, aumentando o tamanho efetivo da população. Mesmo assim, aglomerados de plantas aparentadas poderiam surgir de sementes dispersas por animais.

Esta explicação se adequa bastante no caso da $M$. cinnamomifolia, que tem sementes tanto dispersas por pássaros, que confere uma alta diversidade gênica das subpopulações e baixa divergência entre elas em conseqüência do alto fluxo gênico, e também dispersão de sementes por gravidade, o que pode explicar estruturação espacial verificada nessas populações estudadas, em áreas antropizadas.

\subsection{Distribuição diamétrica da $M$. cinnamomifolia e simulação da diversidade genética em uma população manejada.}

Em relação a distribuição diamétrica da $M$. cinnamomifolia, foram medidos todos os indivíduos nas áreas amostradas em cada subpopulação, encontrando-se uma distribuição normal (Figura 14). Esta distribuição normal, e não em J invertido, é uma característica de espécies iniciais da sucessão, pois como estas ocupam a área, que pode ser uma clareira grande, ao mesmo tempo, existe uma tendência para que os indivíduos da população sejam equiânios. As espécies secundárias, ao contrário, dependem de uma pequena clareira para se desenvolver dispersando-se na floresta. 


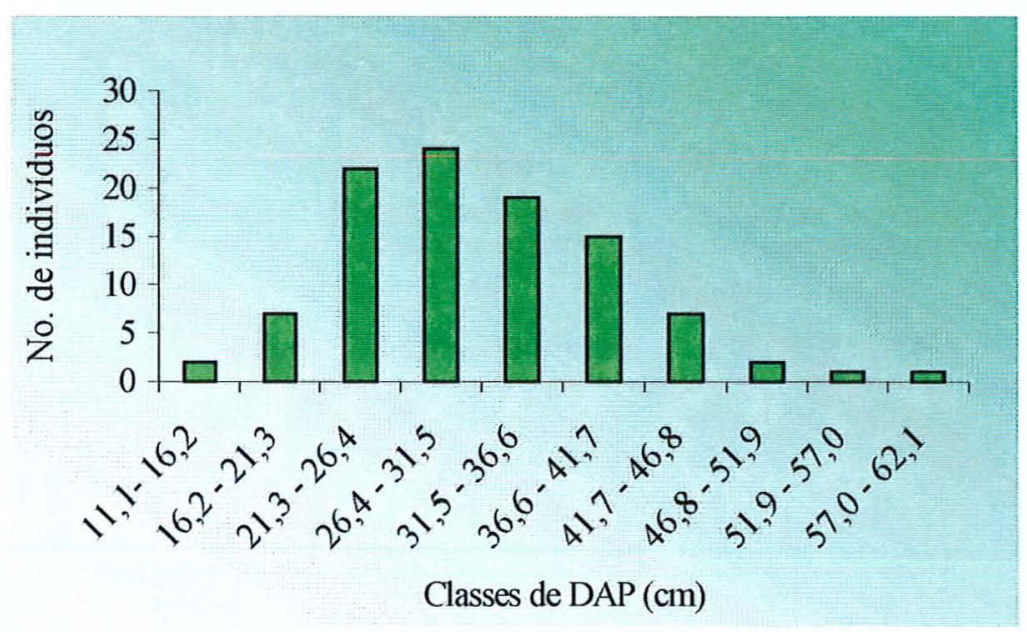

Figura 12 - Distribuição diamétrica $(\mathrm{cm})$ para M. cinnamomifolia.

Pereira et al. (1996) argumenta que a M. cinnamomifolia pode ser utilizada como espécie indicadora da idade de florestas secundárias, pois apresentou capacidade de recrutamento somente até os dez anos, podendo ocorrer nas demais seres somente em clareiras, diferindo bastante de uma espécie rara, com baixa densidade ou menos de um indivíduo por hectare, segundo o conceito de raridade descrito por Bawa \& Ashton (1991). Já segundo Reis, A (comunicação pessoal) essa distribuição do jacatirão varia para florestas primárias, onde pode-se encontrar indivíduos adultos de grande porte isolados, como no Morro do Baú, SC.

Esta conformação em áreas de vegetação secundária é extremamente interessante para o manejo das populações, que podem ser tratadas praticamente como um plantio. $\mathrm{O}$ mais importante é buscar induzir a regeneração natural da espécie a partir do banco de sementes. Neste sentido, o alto índice de diversidade intrapopulacional encontrado no estudo em questão também favorece o manejo, uma vez que a diversidade genética da população não será perdida. Deve-se no entanto deixar bem claro que este é um estudo de caso em populações de áreas que sofreram perturbação antrópica no passado. Já para áreas de floresta primária, onde o jacatirão tem distribuição esparsa, sendo considerada uma espécie com baixa densidade, o manejo sustentável é discutível. 
Foi realizada uma simulação para predizer o quanto de diversidade genética seria perdida caso houvesse extração dos indivíduos com diâmetro acima de $40 \mathrm{~cm}$, tamanho considerado bom para uso industrial. Uma segunda simulação foi feita com extração dos indivíduos com diâmetro acima de $30 \mathrm{~cm}$, o que corresponde a aproximadamente metade da população. Os dados estão apresentados na Tabela 14.

Tabela 14. Índices de diversidade para a população e para duas intensidades de desbaste diferentes ( $>40 \mathrm{~cm}$ de diâmetro e $>30 \mathrm{~cm}$ de diâmetro).

\begin{tabular}{cccc}
\hline & POP conj & $>\mathbf{4 0}(\mathbf{c o n j})$ & $>\mathbf{3 0}$ (conj) \\
\hline $\mathbf{N}$ & 95 & 78 & 49 \\
$\hat{A}$ & 2,43 & $2,43(0,20)$ & $2,14(0,14)$ \\
$\hat{P}(\mathbf{0 , 9 5 )}$ & 0,857 & 1,000 & 0,857 \\
$\hat{H}_{o}$ & 0,407 & $0,414(0,081)$ & $0,448(0,092)$ \\
$\hat{H}_{e}$ & 0,379 & $0,379(0,06)$ & $0,382(0,067)$ \\
$\hat{f}$ & $-0,075(-0,151 \mathrm{a} 0,031)$ & $-0,094(-0,185 \mathrm{a} 0,034)$ & $-0,176(-0,282 \mathrm{a}-0,063)$ \\
$\hat{N}_{e}$ & 103 & 86 & 53 \\
\hline
\end{tabular}

n: número de indivíduos; $\hat{A}$ : número de alelos por loco; $\hat{P}$ : Porcentagem de locos polimórficos; $\hat{H}_{0}$ : heterozigosidade observada; $\hat{H}_{e}$ : heterozigosidade esperada e $\hat{f}$ : índice de fixação.

Pode-se constatar pelos índices encontrados que retirando-se apenas árvores com DAP acima de $40 \mathrm{~cm}$ os índices quase não se alteram, o que é explicado pelo baixo número de indivíduos retirados (17). Já para um desbaste maior (46 indivíduos com DAP $>$ de $30 \mathrm{~cm}$ ) o número de alelos por loco cai, o que indica uma perda de alelos, mas no geral não afeta a diversidade genética da população. O leve acréscimo tanto na heterozigosidade esperada como na heterozigosidade observada é provavelmente causado pela deriva. Cornuet \& Luikart (1996) explicam que, quando uma população passa por uma redução no seu tamanho efetivo, geralmente desenvolve um excesso de heterozigosidade em locos neutros. O excesso de heterozigosidade persiste apenas por um certo número de gerações, até que um novo equilíbrio se estabeleça.

Apesar dos índices de diversidade não apontarem grandes perdas para as populações manejadas, Souza (1997) constatou que a heterozigosidade, um dos 
principais índices de diversidade genética, não seria o mais adequado para quantificar as mudanças genéticas após a fragmentação. Em simulação de fragmentação de uma população de Chorisia speciosa, a autora encontrou que quando as frequiências alélicas são analisadas diretamente é possível observar a perda e fixação de alelos, levando a crer que a porcentagem de alelos perdidos (alelos raros) é o melhor indicativo de perda de variabilidade genética.

Nei et al. (1975) notaram que a diversidade alélica é reduzida mais rápido do que a heterozigosidade durante um gargalo, como o que foi simulado para $M$. cinnamomifolia. Mori (1993) estudando seleção em populações de Eucalyptus grandis e Hamrick (1991) estudando 16 populações naturais de Pinus taeda também registraram perda de alelos da ordem de $17 \%$ e $40 \%$, respectivamente.

Visando verificar se houve perda de alelos para as simulações de desbaste foi realizada uma nova análise das freqüências alélicas para as duas intensidades de extração. Como é possivel perceber na Tabela 15, para a simulação de desbaste acima de $40 \mathrm{~cm}$ não resultou em grandes modificações nas freqüências alélicas. Já para o desbaste acima de $30 \mathrm{~cm}$, retirando-se cerca de metade da população, foram perdidos 2 alelos, que ocorriam em baixa freqüência na população 2 (alelo 3 da EST-1 e alelo 3 da EST-2), o que corresponde à uma perda de $11,7 \%$ do total de alelos na população. 
Tabela 15. Frequências alélicas para as simulações de desbaste de árvores com DAP acima de $40 \mathrm{~cm}$ e DAP acima de $30 \mathrm{~cm}$ em $M$. cinnamomifolia.

\begin{tabular}{|c|c|c|c|c|}
\hline & Alelos & População & 540 & S 30 \\
\hline \multirow[t]{4}{*}{ GDH-1 } & 1 & 0,091 & 0,086 & 0,074 \\
\hline & 2 & 0,048 & 0,053 & 0,064 \\
\hline & 3 & 0,860 & 0,862 & 0,862 \\
\hline & $n$ & 93 & 76 & 47 \\
\hline \multirow[t]{3}{*}{ PGI-1 } & 1 & 0,500 & 0,507 & 0,467 \\
\hline & 2 & 0,500 & 0,493 & 0,533 \\
\hline & $\mathrm{n}$ & 90 & 73 & 45 \\
\hline \multirow[t]{3}{*}{ LAP-1 } & 1 & 0,471 & 0,482 & 0,487 \\
\hline & 2 & 0,529 & 0,518 & 0,513 \\
\hline & $n$ & 68 & 56 & 39 \\
\hline \multirow[t]{3}{*}{ SKDH-1 } & 1 & 0,958 & 0,949 & 0,98 \\
\hline & 2 & 0.042 & 0,051 & 0,02 \\
\hline & $\mathrm{n}$ & 95 & 78 & 49 \\
\hline \multirow[t]{3}{*}{ DIA-1 } & 1 & 0,777 & 0,787 & 0,745 \\
\hline & 2 & 0,223 & 0,213 & 0,255 \\
\hline & n & 92 & 75 & 47 \\
\hline \multirow[t]{4}{*}{ EST-1 } & 1 & 0,551 & 0,570 & 0,533 \\
\hline & 2 & 0,443 & 0,423 & 0,467 \\
\hline & 3 & 0,006 & 0,007 & 0 \\
\hline & $\mathrm{n}$ & 88 & 71 & 45 \\
\hline \multirow[t]{4}{*}{ EST-2 } & 1 & 0,649 & 0,653 & 0,603 \\
\hline & 2 & 0,345 & 0,339 & 0,397 \\
\hline & 3 & 0,007 & 0,008 & 0 \\
\hline & $n$ & 74 & 59 & 39 \\
\hline Total de alelos & & 17 & 17 & 15 \\
\hline
\end{tabular}


Sebbenn et al. (2001), em estudo sobre o efeito do manejo na estrutura genética de populações de caixeta (Tabebuia cassinoides) também detectaram a perda de três alelos raros na população manejada e avaliaram que para o manejo da espécie ser geneticamente sustentável deveria se manter pelo menos 60 plantas reprodutivas por hectare.

O que se pode concluir a partir destes dados é que, quanto maior a redução do tamanho da população, maior será a perda de alelos. Do ponto de vista da conservação genética, isto é preocupante pois estes alelos podem ser importantes para a contínua evolução das populações. Entretanto, para predizer com certeza as conseqüências genéticas dos índices de estruturação e perda de diversidade alélica é necessário realizar estudo com outras gerações (plântulas e banco de sementes). 


\section{CONCLUSÕES}

Em relação ao histórico de perturbação ocorrido no fragmento e entorno, foi possivel concluir que as maiores perturbações, como extração seletiva de madeiras nobres e abertura de clareiras para produção de carvão, ocorreram durante a década e 60 e 70 . Desde então, o entorno do fragmento foi totalmente ocupado pela cultura do eucalipto, formando um corredor de plantio homogêneo entre o fragmento e a Serra do Mar. Este histórico pode ter condicionado a formação de maciços de jacatirão nas áreas de borda do fragmento.

As subpopulações, distantes entre si cerca de $1,5 \mathrm{~km}$, apresentaram altos índices de variabilidade genética, se comparadas a outras espécies arbóreas da Mata Atlântica. As freqüências alélicas não diferiram para entre as subpopulações, tendo sido encontrados dois alelos raros apenas na subpopulação 2 .

Os valores médios encontrados de $\hat{f}$ e $\hat{F}$ similares, negativos e não significativos indicam ausência de endogamia tanto para a média das subpopulações como para o conjunto de subpopulações, o que sugere que a espécie é de cruzamento e que não existe divergência genética, como foi confirmado pelo $\hat{\theta}_{p}$.

A análise da taxa de cruzamento aparente próximo de 1 também refletiu os índices de fixação negativos, podendo-se concluir definitivamente que a espécie apresenta cruzamento preferencial. Em relação ao Equilíbrio de Hardy-Weinberg, conclui-se através do Teste $\mathrm{P}$ de Fischer que a população de adultos da $M$. cinnamomifolia se adequou as proporções do equilíbrio para a maioria dos locos. 
As subpopulações apresentaram um certo grau de estruturação genética espacial, levando a conclusão que os genótipos não estão distribuídos aleatoriamente, ou seja, que os indivíduos mais próximos são mais aparentados, podendo ocorrer problemas como endogamia, o que compromete a viabilidade das gerações futuras.

Em relação ao manejo da espécie, pôde-se concluir que, embora populações em áreas antropizadas consigam manter altos índices de variabilidade genética, um desbaste de $50 \%$ dos indivíduos adultos favorece a perda de alelos raros, embora os índices de diversidade não sofram grandes alterações. Isto indica que o número de alelos é o melhor parâmetro para investigar as mudanças genéticas ocorridas em uma situação de manejo.

Como considerações finais é necessário salientar que a implementação de algumas práticas de manejo da paisagem, podem contribuir para a conectividade do fragmento com outros fragmentos e áreas maiores da Floresta Atlântica, como a Serra do Juqueriquere e os Parques Estaduais da Serra do Mar. A recomendação seria mapear os talhões das fazendas adjacentes para um planejamento integrado da implantação e corte do eucalipto, de maneira que fosse possível a permanência de vários estágios de regeneração do subbosque, ao longo do ciclo de produção. Além disto, a presença de faixas com vegetação nativa entre os talhões também possibilitaria uma maior porosidade da paisagem, permitindo a continuidade do fluxo gênico.

Por outro ponto de vista, áreas de vegetação secundária podem ter um valor econômico para pequenos proprietários a partir do manejo de espécies para fornecimento de madeira, como o jacatirão, que apresenta uma alta densidade de indivíduos, sendo recomendável um desbaste criterioso para evitar a perda de diversidade alélica. Além disto é necessário o monitoramento a condução da regeneração natural para que a população possa se restabelecer, compondo um novo ciclo. 
Anexos 
Anexo 1. Protocolo de coloração para as enzimas utilizadas na eletroforese.

6PGDH (EC 1.1.1.44) - 6- Fosfogluconato desidrogenase :

Ácido 6-fosfoglucônico, $\mathrm{Na}_{3}$

$\mathrm{NADP}^{+}, \mathrm{Na}_{2}$ $20 \mathrm{mg}$

MTT

$1 \mathrm{ml}$

PMS

$1 \mathrm{ml}$

$\mathrm{MgCl}_{2}(1 \%)$

$1 \mathrm{ml}$

Tampão Tris $\mathrm{HCl} 0,1 \mathrm{M}$ pH8,0

$1 \mathrm{ml}$

Procedimento: Diluir todos os reagentes no tampão e imergir os géis nesta solução para incubação no escuro a $37^{\circ} \mathrm{C}$.

\section{LAP (EC 3.4.11.1) Leucina Aminopeptidade}

Método 3.

L- Leucina- $\beta$-naftilamida

Dimetilformamida (DMF)

$10 \mathrm{mg}$

Fast black K salt

$2,5 \mathrm{ml}$

Tampão fosfato de Potassio $0,1 \mathrm{M} \mathrm{pH} 6,0$

$25 \mathrm{mg}$

$50 \mathrm{ml}$

Procedimento: Dissolver a L- Leucina- $\beta$-naftilamida no Dimetilformamide e o fast Black K salt em $1 \mathrm{ml}$ de acetona $1 \%$. Adicionar o tampão aos reagentes e imergir os géis nesta solução para incubação no escuro a $37^{\circ} \mathrm{C}$.

\section{ACP (EC 3.1.3.2) - Fosfatase ácida}

$\alpha$ - naftil fosfato ácido de sódio

$50 \mathrm{mg}$

Fast Garnet GBC salt

$\mathrm{MgCl} 2$

$50 \mathrm{mg}$

Tampão acetato de sódio $0,1 \mathrm{M}$ pH5,0

$1 \mathrm{ml}$

Procedimento: Dissolver o Fast Garnet GBC salt em $1 \mathrm{ml}$ de acetona $1 \%$ e adicionar

todos os reagentes.Imergir os géis na solução para incubação no escuro a $37^{\circ} \mathrm{C}$.

\section{MR (EC 1.6.99.3) - Menadiona Redutase}

Menadiona

MADH

MTT

Tampão Tris $\mathrm{HCl} 0,1 \mathrm{M} \mathrm{pH7,0}$
$17,5 \mathrm{mg}$

$15 \mathrm{mg}$

$1 \mathrm{ml}$

$50 \mathrm{ml}$

Procedimento: Diluir todos os reagentes no tampão e imergir os géis nesta solução para incubação no escuro a $37^{\circ} \mathrm{C}$. 
DIA (EC1.6.4.3) - Diaforase

$\begin{array}{ll}\text { NADH } & 15 \mathrm{mg} \\ \text { MTT } & 1 \mathrm{ml} \\ \text { 2,6-Diclorofenl-indofenol } & 1 \mathrm{mg} \\ \text { Tampão Tris HCl } 0,05 \mathrm{M} \mathrm{pH} 8,0 & 50 \mathrm{ml}\end{array}$

Procedimento: Procedimento: Diluir todos os reagentes no tampão e imergir os géis nesta solução para incubação no escuro a $37^{\circ} \mathrm{C}$.

IDH (EC 1.1.1.42) - Isocitrato Desidrogenase

Dl.- ácido isocitrico, $\mathrm{Na}_{3}$

$\mathrm{NADP}^{+}, \mathrm{Na}_{2}$

$100 \mathrm{mg}$

$1 \mathrm{ml}$

MTT

$1 \mathrm{ml}$

PMS

$1 \mathrm{ml}$

$\mathrm{MgCl}_{2}(1 \%)$

Tampão Tris HCl 0,1 M, pH 8,0

$1 \mathrm{ml}$

$50 \mathrm{ml}$

Procedimento: Diluir todos os reagentes no tampão e imergir os géis nesta solução para incubação no escuro a $37^{\circ} \mathrm{C}$.

SKDH (EC1.1.1.25) - Shiquimato Desidrogenase

$\begin{array}{ll}\text { Ácido Shiquimico } & 50 \mathrm{mg} \\ \mathrm{NADP}^{+}, \mathrm{Na}_{2} & 1 \mathrm{ml} \\ \text { MTT } & 1 \mathrm{ml} \\ \text { PMS } & 1 \mathrm{ml} \\ \text { Tampão Tris } \mathrm{HCl} 0,1 \mathrm{M}, \mathrm{pH} 8,5 & 50 \mathrm{ml}\end{array}$

Procedimento: Diluir todos os reagentes no tampão e imergir os géis nesta solução para incubação no escuro a $37^{\circ} \mathrm{C}$.

GDH (EC 1.4.1.3) - Glutamato Desidrogenase

$\begin{array}{ll}\text { Ácido L-glutâmico, } \mathrm{Na}, 1 \mathrm{M}, \mathrm{pH} 8,0 & 10 \mathrm{ml} \\ \text { NAD } & 1 \mathrm{ml} \\ \text { MTT } & 1 \mathrm{ml} \\ \text { PMS } & 1 \mathrm{ml} \\ \mathrm{MgCl}_{2}(1 \%) & 1 \mathrm{ml} \\ \text { Tampão Tris HCl } 0,1 \mathrm{M}, \mathrm{pH} 8,0 & 50 \mathrm{ml}\end{array}$

Procedimento: Diluir todos os reagentes no tampão e imergir os géis nesta solução para incubação no escuro a $37^{\circ} \mathrm{C}$. 
G6PDH (EC 1.1.1.44) - Glucose 6 Fosfato Desidrogenase

Glucose 6-fosfato

$100 \mathrm{mg}$

$1 \mathrm{ml}$

$\mathrm{NADP}^{+}, \mathrm{Na}_{2}$

MTT

PMS

$\mathrm{MgCl}_{2}(1 \%)$

Tampão Tris $\mathrm{HCl} 0,2 \mathrm{M}$, pH 8,0

$1 \mathrm{ml}$

$1 \mathrm{ml}$

$1 \mathrm{ml}$

$50 \mathrm{ml}$

incubação no escuro a $37^{\circ} \mathrm{C}$.

PGI (EC 5.3.1.9) - Fosfoglucose isomerase

Frutose 6 fosfato, $\mathrm{Na}_{2}$

$\mathrm{NADP}^{+}, \mathrm{Na}_{2}$

$37,5 \mathrm{mg}$

MTT

$1 \mathrm{ml}$

PMS

$1 \mathrm{ml}$

$\mathrm{MgCl}_{2}(1 \%)$

$1 \mathrm{ml}$

Tampão Tris $\mathrm{HCl} 0,1 \mathrm{M}, \mathrm{pH} 8,0$

$1 \mathrm{ml}$

Procedimento: Diluir todos os reagentes no tampão e acrescentar ao final $6,5 \mu 1 \mathrm{de}$ Glucose 6 fosfato desidrogenase (G6PDH). Imergir os géis nesta solução para incubação no escuro a $37^{\circ} \mathrm{C}$.

$\alpha$ - Esterase (EC 3.1.1.1) - Esterase

$\alpha, \beta$ - naftil-acetato $1 \%$ em acetona $50 \% \quad 1,5 \mathrm{ml}$

Fast Garnet GBC $\quad 50 \mathrm{mg}$

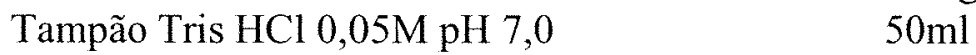

Procedimento: Dissolver o Fast Garnet GBC salt em $1 \mathrm{ml}$ de acetona $1 \%$ e adicionar todos os reagentes. Imergir os géis na solução para incubação no escuro a $37^{\circ} \mathrm{C}$. 
Anexo 2. Correlogramas para todos os alelos descritos nas Tabelas 12 e 13 .

DLA

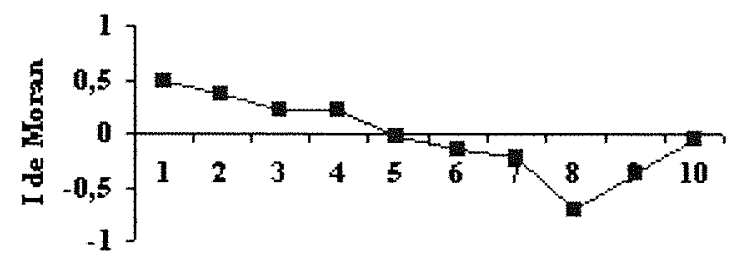

Classes de distância

EST-2

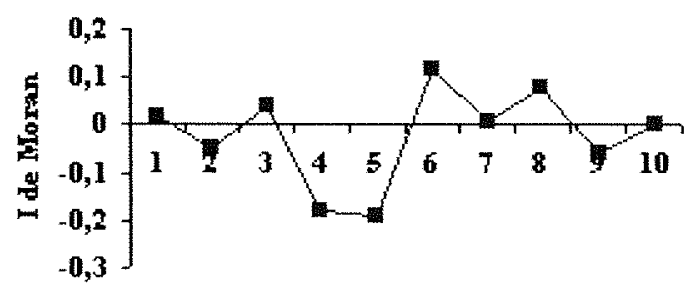

Classes de distância

GDH-1

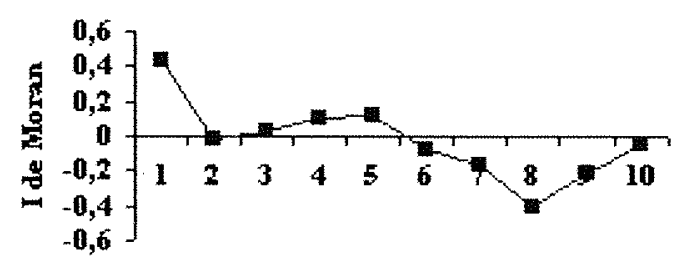

Classes de distäncia

GDH-2

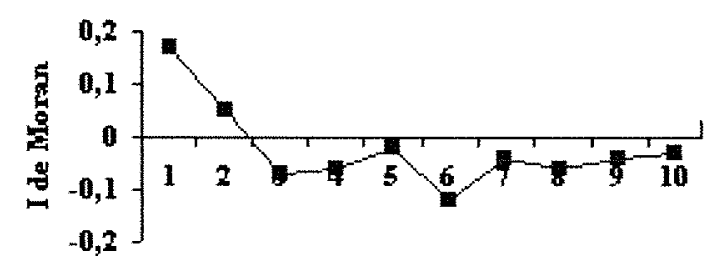

Classes de distância

Figura 13 - Correlogramas para os alelos DIA alelo1, EST-2 alelo 1, GDH alelo 1 e GDH alelo 2 na subpopulação 1 de $M$. cinnamomifolia. 
GDH-3

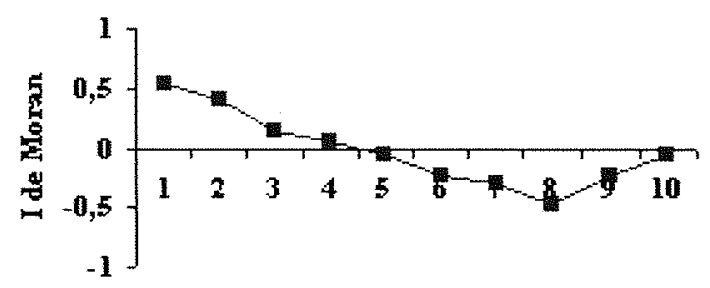

Classes de distância

LAP-1

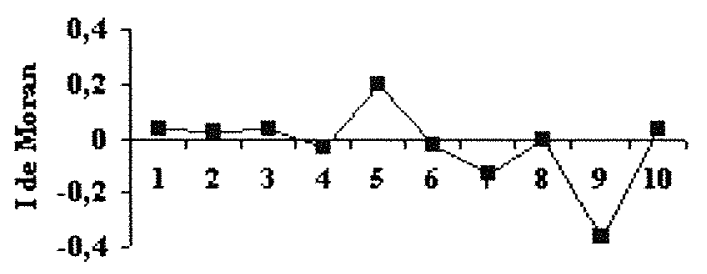

Classes de distância

PGI-1

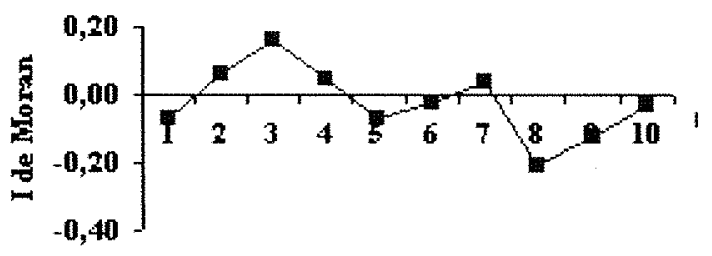

Classes de distância

SKDH

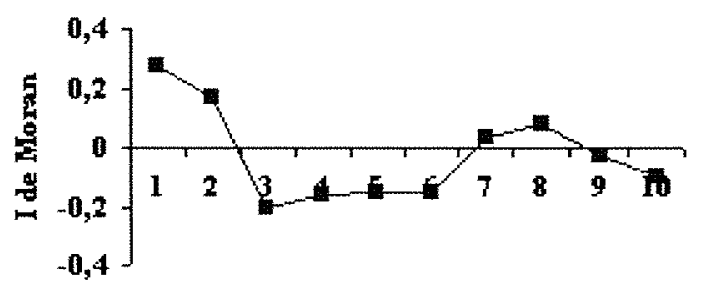

Classes de distância

Figura 14 - Correlogramas para os alelos GDH alelo 3, LAP alelo 1, PGI alelo 1 e SKDH alelo 1 na subpopulação 1 de M. cinnamomifolia 
EST-1

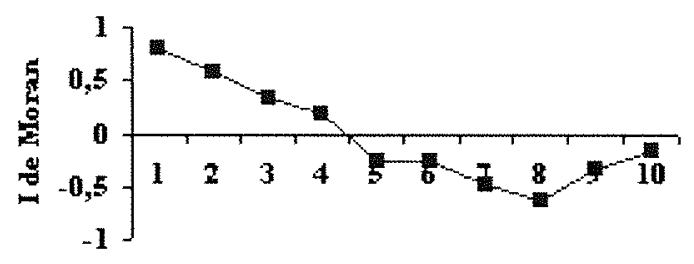

Classes de distância

DLA-1

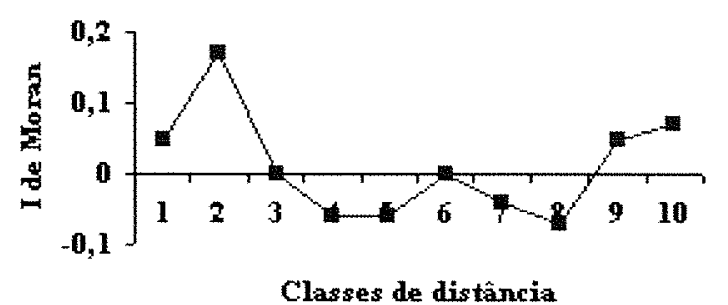

EST-1 alelo 2

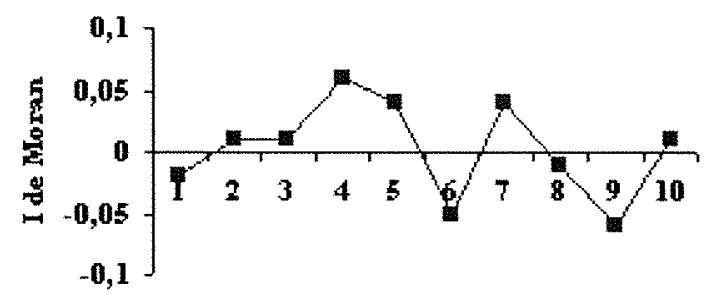

Classes de distância

EST-1 alelo 1

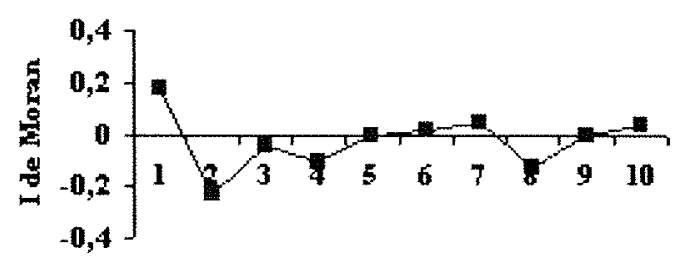

Classes de distância

Figura 15 - Correlogramas para os alelos EST-1 alelo 1 na subpopulação 1 e alelos DIA1 alelo 1, EST-1 alelo 2, , EST -1 alelo 1 na subpopulação 2 de $M$. cinnamomifolia. 
EST-1 ale Io 3

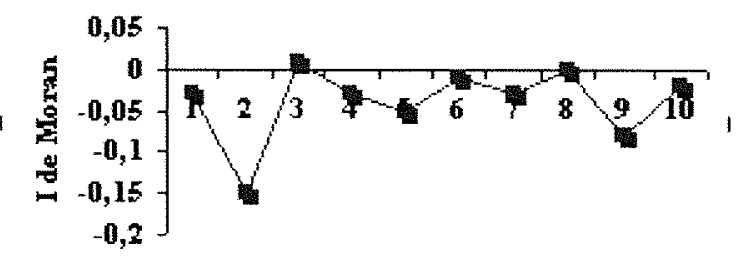

Classes de distancia

EST-2 alelo 1

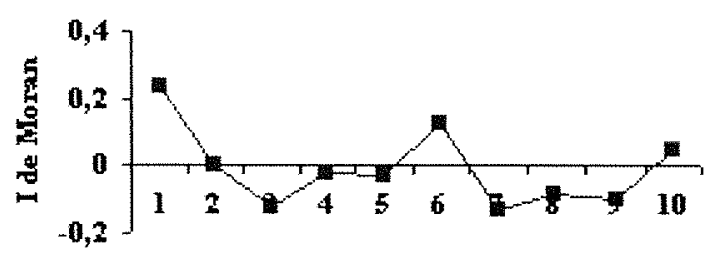

Classes de distância

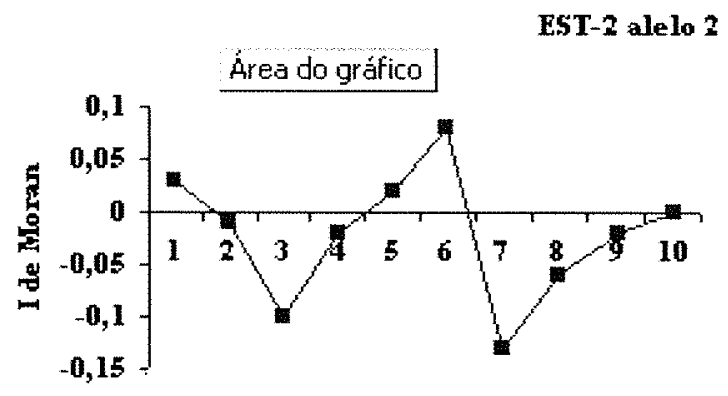

Classes de distância

EST-2 alelo 3

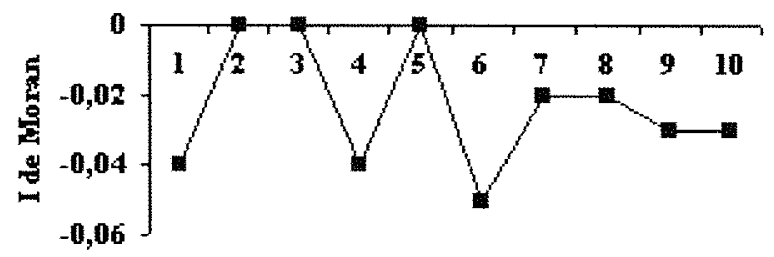

Classes de distancia

Figura 16 - Correlogramas para os alelos EST-1 alelo 3, EST-2 alelo 1, EST-2 alelo 2 e EST-2 alelo 3 na subpopulação 2 de $M$. cinnamomifolia. 
GDH-1

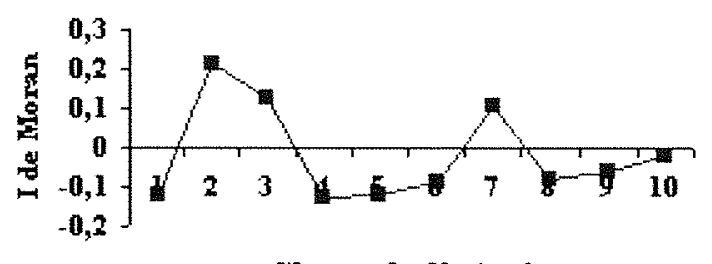

Classes de distância

GDH-2

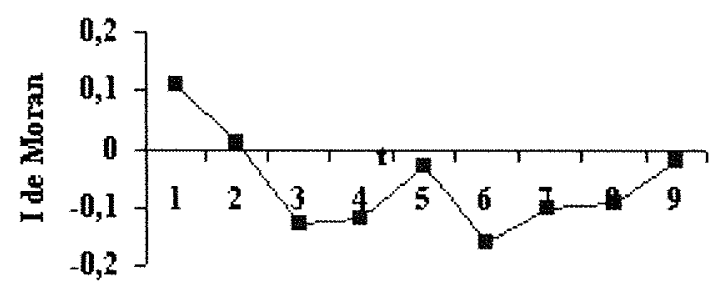

Classes de distância

GDH-3

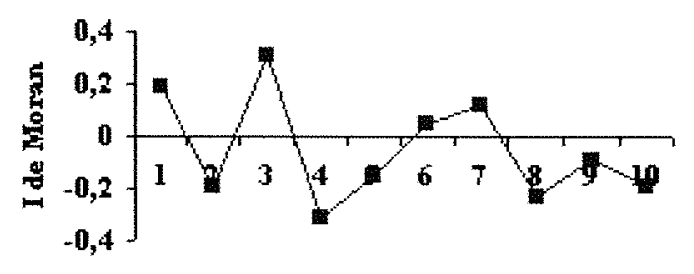

Classes de distância

LAP-1

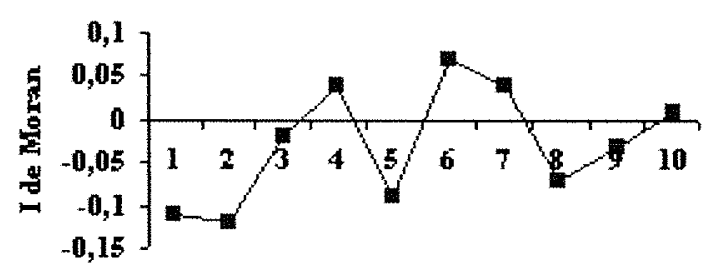

Classes de distäncia

Figura 17 - Correlogramas para os alelos GDH-1 alelo 1, GDH-1 alelo 2, GDH-1 alelo 3 e LAP-1 alelo 1 na subpopulação 2 de $M$. cinnamomifolia. 
PGI-1

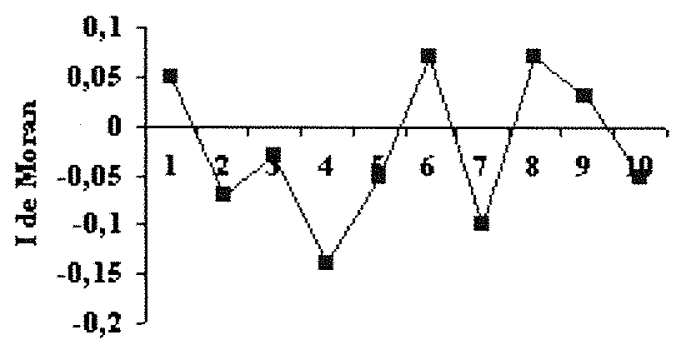

Classes de distância

SKDH-1

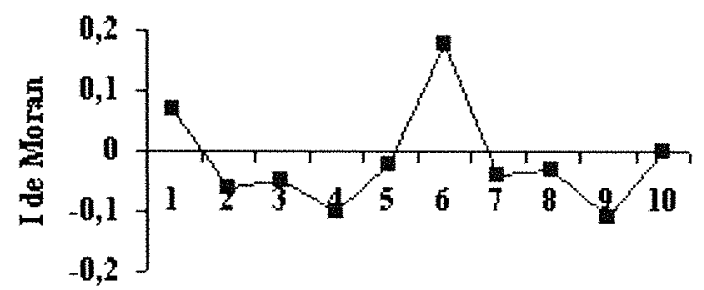

Classes de distância

Figura 18 - Correlogramas para os alelos PGI-1 alelo 1 e SKDH-1 alelo 1 na subpopulação 2 de $M$. cinnamomifolia. 


\section{REFERÊNCIAS BIBLIOGRÁFICAS}

ALFENAS, A.C. Eletroforese de proteínas e isoenzimas de fungos e essências florestais. Viçosa: SIF, 1991. 242p.

ALMEIDA, J.R. Gestão ambiental: planejamento, avaliação, implantação, operação e verificação. Rio de Janeiro: Thex Ed., 2001. 259p.

BAER, W.; MUELLER, C.C.: Environmental aspects of Brazil's development. In: WERNER, B. (Ed.) The Brazilian economy. Connecticut: Praeger, 1995. p. 27-44.

BALLAL, S.R.; FORÉ, S.A; GUTTMAN, S.I. Apparent gene flow and genetic structure of Acer saccharum subpopulation in forest fragments. Canadian Journal of Botany, v.72, p.1311-1315, 1994.

BARRET, S.C.H.; KOHN, J.R. Genetic and evolutionary consequences of small population size in plants: Implications for conservation In: FALK, D.A.; HOLSINGER, K.E. (Ed.) Genetics and conservation of rare plants. St. Louis: Oxford University Press, 1991. p.3-30.

BAUNDRY, J. Interactions between agricultutal and ecological systems at the landscape level. Agriculture, Ecosystems and Environment, v.27, p.119-130, 1989. 
BAWA, K.S.; ASHTON, P.S. Conservation of rare trees in tropical rain forests: a genetic perspective. In: FALK, D. A.; HOLSINGER, K.E. (Ed.) Genetics and conservation of rare plants. St. Louis: Oxford University Press, 1991 p.3-30.

BERGMANN, F.; GREGORIOUS, H.R.; LARSEN, J.B. Levels of genetic variation in European silver fir (Abies alba) - are they related to the species'decline? Genetica, v.82, p.1-10, 1990.

BOYLE, T.; YOUNG, A.G. Forest fragmentation. In: YOUNG,A., BOSHIER, D.; BOYLE,T. (Ed.) Forest conservation genetics: principles and practice. Collingwood: CSIRO, 2000. p.123-132.

BUDOWSKI, G. Distribuition of tropical american rain forest in the light of sucessional process. Turrialba, v.15, n.1, p.40-42, Jan. 1965.

CARVALHO, P.E.R. Espécies florestais brasileiras: recomendações silviculturais, potencialidades e uso da madeira. Colombo: EMBRAPA,CNPF, 1994.640p.

CORNUET, J.M.; LUIKART, G. Description and power analysis of two tests for detecting recent population bottlenecks from allele frequency data. Genetics, v.14, p.2001-2014. Dec.1996.

FISCHER, G.R. Algumas observações em torno do Jacatirão Açu. Brasil Florestal, v.4, n.13, p.49-51, 1973.

FORÉ, S.A.; HICKEY, R. J.; VANKAT, J.L.; GUTTMAN, S.; SHAEFER, R. Genetic structure after forest fragmentation: a landscape ecology perspective on Acer saccharum. Canadian Journal of Botany, v.70, p.1659-1668, 1992. 
FORMAN, R.T.T.; GODRON, M. Landscape ecology. New York: John Willey, 1986. $639 \mathrm{p}$.

FRANKEL, O. H.; SOULÉ, M. Conservation and evolution. Cambrige: Cambrige University Press, $1981.327 \mathrm{p}$.

FRANKEL, O.H.; SOULÉ, M. The place of management in conservation. In: SHONEWALD-COX, C.M.; CHAMBERS, S.M.; MACBRYDE,B.; THOMAS, W.L. (Ed) Genetics and conservation: a reference for managing wild animals and plants populations. Menlo Park: The Benjamin/Cumings, 1983.p. 1-14.

FRANKEL, O. H.; BROWN, A. H.D.; BURDON, J.J. The conservation of plant biology. Cambrige: Cambrige University Press, 1995. 335p.

FUTUYMA, D.J. Biologia evolutiva. Ribeirão Preto: Sociedade Brasileira de Genética 1992. $631 \mathrm{p}$.

GLAUBITZ; J. C. \& MORAN, G. F. Genetic tools: the use of biochemical and molecular markers. In: YOUNG, A.; BOSHIER, D.; BOYLE, T. (Ed.) Forest conservation genetics: principles and practice. Collingwood: CSIRO, 2000. p.3959.

GILBERT, L.E. Food web organization and conservation of neotropical diversity. In: SOULÉ, M.E. (Ed.) Conservation biology. Sunderland: Sinauer,1986. p.11-33.

HAMRICK, J.L.; LOVELESS, M.D. The genetic structure of tropical tree populations: association with reproductive biology. In: BOCK, J. H.; LINHART, Y. B. (Ed.) The evolutionary ecology of plants. Boulder: Westview Press, 1989. p.129-146. 
HAMRICK, J.L., Isozymes and analysis of genetic structure in plant populations. In: SOLTIS, D.E; SOLTIS, P. (Ed.) Isozymes and analysis of genetic structure in plant populations. Portland: Chapmanand Hall. 1990, p.87-105.

HAMRICK, J.L.; GODT, M.J.W. Allozyme diversity in plant species. In: BROWN, A.H.D.; CLEGG, M.T.; KAHLER, A.L.; WEIR, B.S. (Ed.) Plant population genetics, breeding and genetic resources. Sunderland: Sinauer, 1990. p.43-63.

HAMRICK, J.L. Allozyme diversity of natural stands versus seed orchad loblolly pine. In: MEETING CANADIAN TREE IMPROVEMENT ASSOCIATION, 23., Ottawa, 1991. Proccedings. Ottawa: IDRC, 1991. p.1-21.

HANSKI, I.; SIMBERLOFF, D. The Metapopulation approach, its history, conceptual domain, and aplication to conservation. In: HANSKY, I;; GILPIN, M.E. (Ed.) Metapopulation biology: ecology, genetics and evolution. San Diego: Academic Press, 1997. p 5-26.

HUENNEKE, L.F. Ecological implications of genetic variation in plant population. In: FALK, D.A.; HOLSINGER, K.E. (Ed.) Genetics and conservation of rare plants. St. Louis: Oxford University Press, 1991. p.3-30.

JELINSKY, D.E. On genes and geography: a landscape perspective on genetic variation in natural populations. Landscape and Urban Planning, v.39, p.11-23, 1997.

KAGEYAMA, P.Y. Conservação "in situ" de recursos genéticos de plantas. IPEF, n.35, p.7-37, 1987. 
KAGEYAMA, P.Y.; REIS, A. Areas of secondary vegetation in the Itajai Valley, Santa Catarina, Brazil. Perspectives for management and conservation. Forest Genetic Resourses Information. v.21. p.37-39, 1993.

KAGEYAMA, P.Y.; GANDARA, F.B.; SOUZA, L.M.I. Conseqüências genéticas da fragmentação sobre populações de espécies arbóreas. Série Técnica do IPEF, v.12, n.32, p.65-70, dez.1998.

KAGEYAMA, P.Y.; GANDARA. F.B. Revegetação de áreas ciliares. In: RODRIGUES, R.R.; LEITÃO FILHO,H.F. (Ed.) Matas ciliares: conservação e recuperação. São Paulo: Editora da USP, FAPESP, 2000. 320p.

KAGEYAMA, P.Y.; GANDARA, F.B.; VENCOVSKY, R. Conservação in situ de espécies arbóreas tropicais. In: NASS, L.L. et al. (Ed.) Recursos genéticos e melhoramento - plantas. Rondonópolis: Fundação MT, 2001. p 150-158.

KEARNS, C.A.; INOUYE, D.W.; WASER, N.M. Endangered mutualisms: the conservation of plant- pollinator interactions. Annual Review Ecology System, v.29, p.83-112, 1998.

KLEIN, R.M. Ecologia da flora e vegetação do Vale do Itajaí. Sellowia, v.31, n.31, p.10-389, 1975 .

LEÃO, R.M. A floresta e o homem. São Paulo: IPEF, 2000. 428p.

LEPCH-CUNHA, N. Estrutura genética e fenologia de espécies raras de Couratari spp. (LECYTHIDACEAE) na Amazônia Central. Piracicaba, 1996. 147p. Dissertação (Mestrado) - Escola Superior de Agricultura "Luiz de Queiroz", Universidade de São Paulo. 
LORENZI, H. Árvores brasileiras: manual de identificação e cultivo de plantas arbóreas nativas do Brasil. Nova Odessa: Ed. Plantarum, 1992. 382p.

LOVELESS, M.D.; HAMRICK, J.L. Ecological determinants of genetic sctruture in plant population. Annual Review of Ecology and Systematics, v.15, p.65-95, 1984.

MacARTHUR, R.H.; WILSON, E.O. The theory of island biogeography. Princeton: Princeton University Press, 1967. 152p.

MANTOVANI, W.; RODRIGUES, R. R.; ROSSI, L. et al. A vegetação na Serra do Mar em Salesópolis, SP. In: SIMPÓSIO DE ECOSSITEMAS DA COSTA SUL E SUDESTE DO BRASIL: ESTADO, FUNÇÃO E MANEJO, Águas de Lindóia, 1990. Anais. Águas de Lindóia: SBB, 1990. p.348-384.

MARTINS, P.S. Estrutura populacional, fluxo gênico e conservação in situ. IPEF, n.35, p.71-78, 1987.

MARRUCCI, D.J. Landscape history as a planning tool. Landscape and Urban Planning, v.49, p.67 -81, 1999.

MARUYAMA, T.; FUERST, P.A. Population botttlenecks and non-equilibrium models in population genetics. I. Allele numbers when populations envolve from zero variability. Genetics, v.108, p.745-763. 1985.

MORI, E.S. Variabilidade genética isoenzimática em uma população de Eucaliptus grandis Hill ex Maiden submetidas a diferentes intensidades de seleção. Piracicaba, 1993. 118p. Tese (Doutorado) - Escola Superior de Agricultura "Luiz de Queiroz", Universidade de São Paulo. 
MÜLLER-STARCK, G.; SCHUBERT, R. Genetic markers as a tool for bioindication in forest ecosystems. In: YOUNG,A.; BOSHIER,D; BOYLE,T. (Ed.) Forest conservation genetics: principles and practice. Collingwood: CSIRO, 2000. p. 227238.

MURAWSKI, D.A.; BAWA, K.S. Genetic structure and mating system of Stemonoporus oblongifolius (Dipterocarpaceae) in Sri Lanka. American Journal of Botany, v.81, n.2, p.155-160, 1994.

NAMKOONG, G. Preserving natural diversity. In: SHONEWALD-COX, C.M.; CHAMBERS, S.M.; MACBRYDE,B. et al. (Ed.) Genetics and conservation: a reference for managing wild animal and plant populations. Menlo Park: The Benjamin/Cumings, 1983. p.317-334.

NAMKOONG, G., BOYLE, T.J.B.; EL-KASSABY, Y. et al. Testing Criteria and Indicators for Assessing the Sustainability of Forest Management: Genetic Criteria and Indicators. 2000. /no prelo/

NEGRÃO, M. O. Estrutura genética de populações naturais de Syagrus romanzoffiana (ARECACEAE) do Continente (Serra do Mar, SP) e da Ilha dos Alcatrazes. Piracicaba, 1999. 78p. Dissertação (Mestrado) - Escola Superior de Agricultura "Luiz de Queiroz", Universidade de São Paulo.

NEI, M. The theory and estimation of genetic distance. In: MORTON, N.E. (Ed.) Genetic structure of populations. Honolulu: University Press of Hawaii, 1973. p. $45-51$.

NEI, M. Molecular evolutionary genetics. New York: Columbia University Press, $1987,512 \mathrm{p}$. 
NOSS, R.F. Indicators for monitoring biodiversity: a hierarchical approach. Conservation Biology, v.4, n.4. p.355-364, Dec. 1990.

OLIVEIRA, L.M.T. Diagnóstico de fragmentos florestais nativos, em nivel de paisagem, em áreas sob influência da Veracruz Florestal Ltda. Eunapolis. Viçosa, 1997. 74p. Dissertação (Mestrado) - Universidade Federal de Viçosa.

PEREIRA, T.S. Ecologia de Miconia cinnamomifolia (DC.) Naudin.- Jacatirão na sucessão secundária da Mata Atlântica. São Paulo, 1998. 149p. Tese (Doutorado) Instituto de Biociências, Universidade de São Paulo.

PEREIRA, T. S.; OLIVEIRA, R. R.; DELAMONICA, P. et al. Utilização de Miconia cinnamomifolia (DC.) Naud. (Melastomataceae) como indicador da idade de florestas secundárias no Rio de Janeiro. In: CONGRESSO NACIONAL DE BOTÂNICA, 47, Nova Friburgo, 1996. Anais. Rio de Janeiro: UFRJ, 1996. p.365.

PERECIN, M.B. Diversidade genética em população naturais de espécies de EspinheiraSanta, Maytenus aquifolia Mart e M. iliciflolia Mart. Ex Reiss. Piracicaba, 2000. 134p. Tese (Doutorado) - Escola Superior de Agricultura Luiz de Queiroz, Universidade de São Paulo.

QUEIROZ, M. Aspectos preliminares de beneficiamento e germinação de Miconia cinnamomifolia, Silvicultura em São Paulo, v.16 A, n.1, p.318-321, 1982.

QUEIROZ, M. Influência da luz na germinação de Miconia cinnamomifolia. Ínsula, v. 13, p. $29-37,1983$.

RANDI, A. M. Estudo preliminar sobre inibidores de germinação em frutos de Miconia cinnamomifolia e Ocotea puberula. Silvicultura em São Paulo, v.16, n.1, p.238242,1982 . 
REDFORD, K.H.; RICHTER, B.D. Conservation of biodiversity in a world of use. Conservation Biology, v.13, n.6, p.1246-1256, Dec. 1999.

SANTOS. E.M.G. Ecologia da polinização, fluxo de pólen e taxa de cruzamento em Bauhinia forficata Link. (Caesalpinaceae). Piracicaba, 1994. 114p. Dissertação (Mestrado) - Escola Superior de Agricultura "Luiz de Queiroz", Universidade de São Paulo.

SÃo PAULO (Estado) Secretaria dos Serviços e Obras Públicas. Atlas pluviométrico do Estado de São Paulo. São Paulo: Departamento de Águas e Energia Elétrica, 1972. 50p.

SCANDALIOS, J.G. Genetic control of multiple molecular forms on enzimes in plants: a review. Bichemical Genetics, v.3, p.37-39, 1969.

SEBBENN, A..M.; KAGEYAMA, P.Y.; VENCOVSKY, R. Variabilidade genética, sistema reprodutivo e estrutura genética espacial em Genipa americana L. através de marcadores isoenzimáticos. Scientia Forestalis n53, p.15-30, jun., 1998.

SEBBENN, A.M. Amostragem para estimativa de freqüências alélicas e índices de diversidade genética em espécies florestais. Revista do Instituto Florestal, 2001 /no prelo/

SEBBENN, A.M.; SEOANE, C. E. S; KAGEYAMA, P. Y. Efeitos do manejo na estrutura genética de populações de caixeta (Tabebuia cassinoides). Scientia Forestalis, n.58, p.127-143, dez. 2000.

SETZER, J. Contribuições para o estudo do clima do Estado de São Paulo. São Paulo: Escolas Salesianas, 1946. 239p. 
SLATKIN, M. Gene flow and the geografic structure of natural populations. Science v.236, p.787-792, 1987.

SOUZA, L.F.I. Estrutura genética de populações naturais de Chorisia speciosa St. Hill. (Bombacaceae) em fragmentos florestais na região de Bauru (SP). Piracicaba, 1997. 76p. Dissertação (Mestrado) - Escola Superior de Agricultura "Luiz de Queiroz", Universidade de São Paulo.

SWOFFORD, D.L.; SELLANDER, R.B. BIOSYS-2 A computer program for analysis of allelic variation in genetics. Release, 1,7 Illinois: Natural History Survey. 1997. 78p.

YEH, F.C.H. Isozyme analysis for revealing population structure for use in breeding strategies. In: GIBSON, G.L.; GRIFFIN, A.R.; MATHESON, A.C. (Ed.) Breeding tropical trees: population structure and genetic improvement strategy in clonal and seedling forestry. Pattaya: Oxford Institute, 1988. p.119-131.

TABARELLI, M; MANTOVANI, W. A regeneração de uma floresta tropical montana após corte e queima (São Paulo - Brasil). Revista Brasileira de Biologia, v.59 n.2, p.239-250, maio 1999 a.

TABARELLI, M; MANTOVANI, W. Clareiras naturais e a riqueza de espécies pioneiras em uma floresta Atlântica Montana. Revista Brasileira de Biologia, v.59 n.2, p.251-261, maio 1999 b.

TEMPLETON, A. R. Biodiversity at the molecular genetic level: experiences from disparate level: experiences from disparates macroorganisms. In: HAWKSWORTH, D.L. (Ed.) Biodiversity: mensurament and estimation. London: Chapman \& Hall., 1995. p.59-64. 
UNIVERSIDADE FEDERAL DO PARANÁ. Estudos das alternativas técnicas, econômicas e sociais para o setor florestal do Paraná; sub-programa: Tecnologia. Curitiba: SUDESUL,UFPR, 1979. 335p.

VELOSO, H.P.; RANGEL-FILHO, A.L.R.; LIMA, J.C.A. Classificação da vegetação brasileira adaptada a um sistema universal. Rio de Janeiro: IBGE, 1991. p. 31-45.

VENCOVSKY, R. Tamanho efetivo populacional na coleta e preservação de germoplasmas de espécies alógamas. IPEF, n.35. p. 79-84, 1987.

VENCOVSKY, R. Análise de variância de fequências alélicas. Revista Brasileira de Genética, v.15, supl. 1, p. 53-60, 1992.

VENCOVSKY, R. Variance of an estimate of outcrossing rate. Revista Brasileira de Genética, v.17 (3), p.349-351, 1994.

VENCOVSKY, R. Biometrical Approaches for molecular markers: estimation of effective population size. In: INTERNATIONAL WORKSHOP ON AGRICUltural BIOTECHNOLOGY, Piracicaba, 1997. Proceedings. Piracicaba: ESALQ,USP, 1997. p.21-22.

VENCOVSKY, R \& COELHO, A. S. G. Biometria de marcadores genéticos. Piracicaba: USP, ESALQ- Departamento de genética, 1999. 115 p.

VIANA, V.M. Biologia e manejo de fragmentos florestais naturais. In: CONGRESSO FLORESTAL BRASILEIRO, 6. Campos de Jordão, 1990. Anais. Campos de Jordão: SBS,SBEF, 1990. p.113-118.

VIANA, V.M.; Conservação da biodiversidade de fragmentos florestais tropicais em paisagens intensivamente cultivadas. In: CONFERENCIA INTERNACIONAL; “ON 
COMMON AROUND: INTERDICIPLINARY APROACHES BIODIVERSITY AND LAND USE DINAMICS IN THE WORLD", Belo Horizonte, 1995. Anais. Belo Horizonte: FAPEMIG, 1995. p. 324-333.

WADT, L.H.O. Estrutura genética de populações naturais de pimenta longa (Piper hispidinervum C.DC.) visando seu uso e conservação. Piracicaba, 2000. 95p. Tese (Doutorado) - Escola Superior de Agricultura "Luiz de Queiroz", Universidade de São Paulo.

WORLD WILDILIFE FOUNDATION http://www.wwf.org.br/bioma/mataatlantica (15 jan. 2001)

WRIGHT, S. Breeding structure of populations in relation to speciation. American Naturalist, v.74, p.232-248, 1940.

WRIGHT, S. The interpretation of population structure by F-statistics with special regard to sistems of mating. Evolution, v.19, p.395-420, 1965.

WURDACK, J.J. Melastomataceae of Santa Catarina, Santa Catarina. Sellowia, v.14, p.157-158, 1962. 